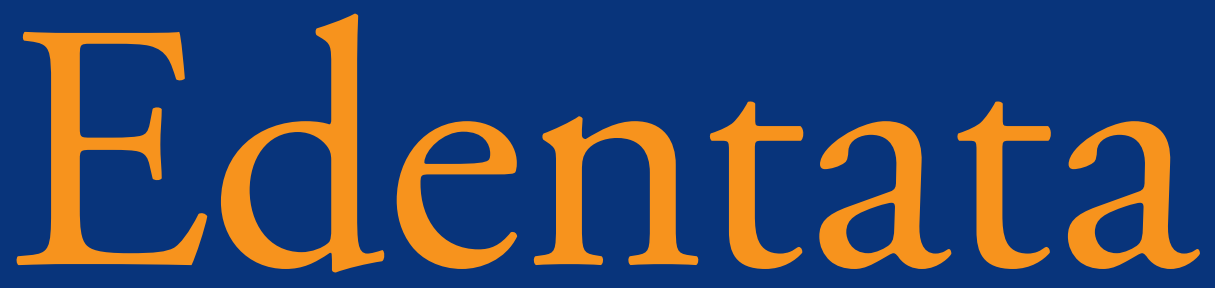

The Newsletter of the IUCN/SSC Anteater, Sloth and Armadillo Specialist Group

December $2019 \bullet$ Number 20
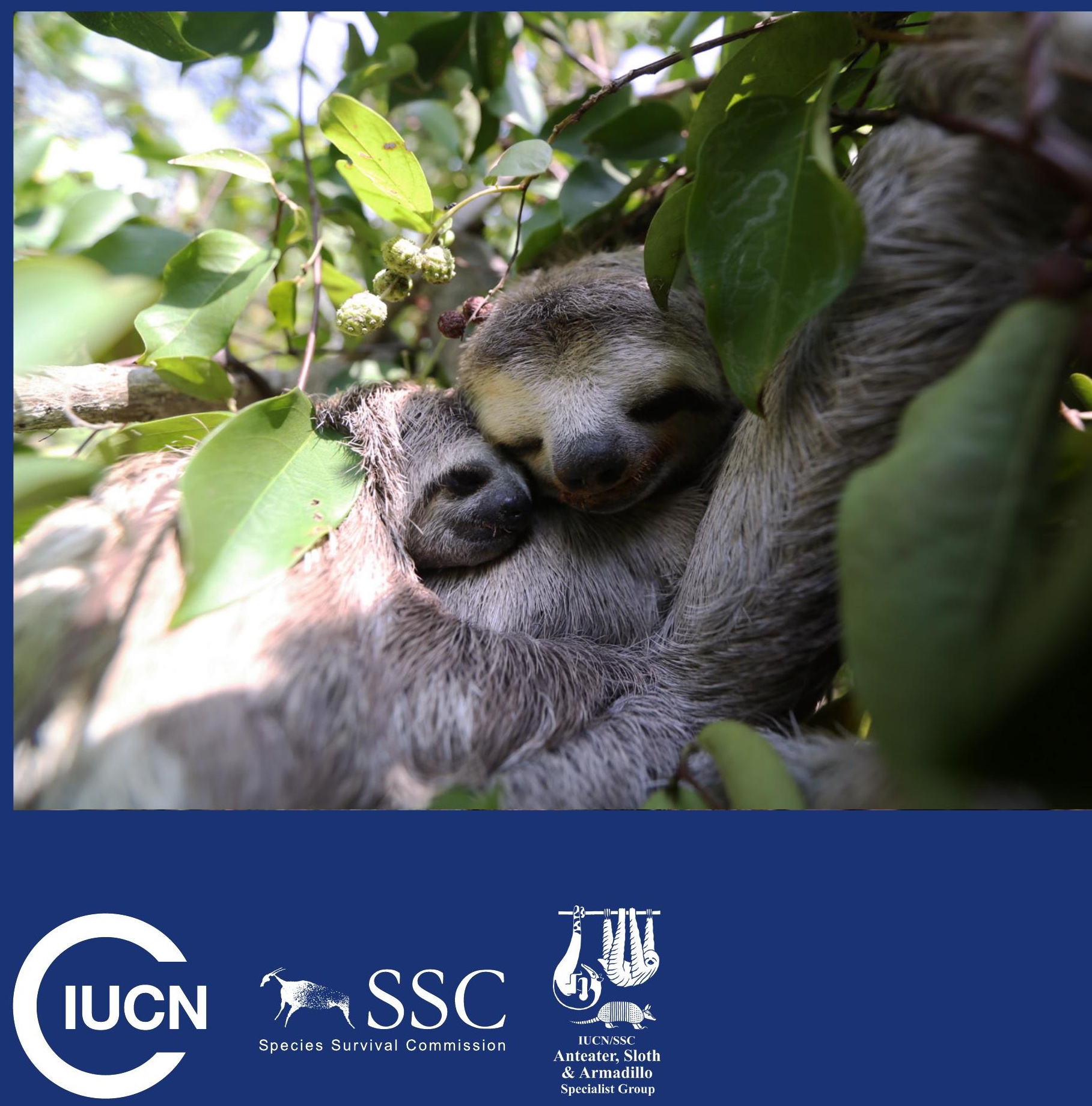

TSSC

Species Survival Commission

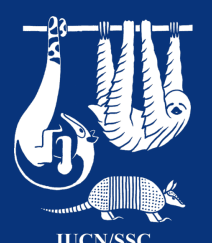

Anteater, Sloth

A Armadillo 


\section{Edentata}

The Newsletter of the IUCN/SSC Anteater, Sloth and Armadillo Specialist Group

ISSN 1413-4411 (print version)

ISSN 1852-9208 (electronic version)

http://www.xenarthrans.org

Editors:

Mariella Superina, IMBECU, CCT CONICET Mendoza, Mendoza, Argentina.

Nadia de Moraes-Barros, Centro de Investigação em Biodiversidade e Recursos Genéticos, Universidade de Porto, CIBIO-InBIO, Porto, Portugal.

Agustín M. Abba, Centro de Estudios Parasitológicos y de Vectores, CCT CONICET La Plata - UNLP, La Plata, Argentina.

Associate editors:

W. Jim Loughry, Valdosta State University, Valdosta, GA, USA.

Roberto F. Aguilar, Clinical veterinarian, Tucson Wildlife Center, Tucson, AZ, USA.

Editorial assistance:

Alessandra Bertassoni, Universidade Federal de Goiás, Brazil.

IUCN/SSC Anteater, Sloth and Armadillo Specialist Group Chair

Mariella Superina

IUCN/SSC Anteater, Sloth and Armadillo Specialist Group Deputy Chair

Nadia de Moraes-Barros

Layout:

Gabriela F. Ruellan, Designer in Visual Communication

The editors wish to thank all reviewers for their collaboration.

Front Cover Photo:

Brown-throated three-toed sloth (Bradypus variegatus). Photo: Fundación AIUNAU

Please direct all submissions and other editorial correspondence to:

Mariella Superina

IMBECU, CCT CONICET Mendoza

Casilla de Correos 855, Mendoza (5500), Argentina

Tel. +54 261-5244160

Fax +54 261-5244001

E-mail:edentata@xenarthrans.org

IUCN/SSC Anteater, Sloth and Armadillo Specialist Group logo courtesy of Stephen D. Nash, 2009.

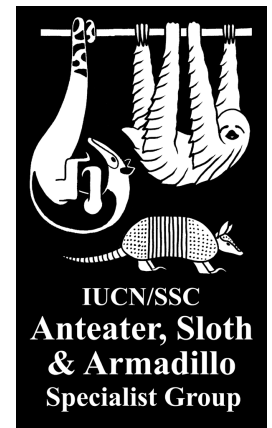




\section{Table of Contents}

Letter from the Editors. ii

IUCN/SSC Anteater, Sloth and Armadillo Specialist Group Members 2017-2020

\section{ARTICLES}

Guidelines to identify individual giant armadillos, Priodontes maximus (Kerr, 1792), through camera traps .1 Gabriel Fávero Massocato \& Arnaud L. J. Desbiez

\section{SHORT COMMUNICATIONS}

Noteworthy records of the northern naked-tailed armadillo, Cabassous centralis (Cingulata: Chlamyphoridae), in Guatemala, Central America.

José Manuel Pellecer, Julio Rafael Morales \& Sergio Guillermo Pérez

Nuevos registros en Huánuco (Perú) y distribución potencial del armadillo peludo (Dasypus pilosus)

E. Daniel Cossios \& Pedro Huanca-Foroca

Nuevos casos de comportamiento agonístico entre machos adultos de Bradypus variegatus en el Caribe colombiano.

Jairo Andrés Díaz Arcia \& Julio J. Chacón Pacheco

Report of three non-agonistic encounters of free-living giant anteaters (Myrmecophaga tridactyla)

Mariana Labão Catapani, Karina Theodoro Molina, Alexandre Martins Costa Lopes \& Flávia Miranda

Reporte de un ejemplar albino de Tamandua tetradactyla (Linnaeus, 1758) (Pilosa, Myrmecophagidae) en el suroeste de Paraguay

Sergio D. Ríos, Christian Ruiz Díaz \& Paul Smith

\section{FIELD NOTES}

Primeiro registro de leucismo em Bradypus variegatus (Schinz 1825, Xenarthra: Bradypodidae), município de Maceió, Alagoas, Brasil.

Ana Cecília Pires de Azevedo Lopes, Epitacio Correia de Farias Junior, Marco Antônio de Freitas \& Karina Theodoro Molina

News..

Notes to Contributors / Pautas para los Colaboradores / Instruções aos Colaboradores 


\section{Letter from the Editors}

Welcome to another issue of Edentata! Edentata 20 includes one full article, four short communications, two field notes, and a News section packed with interesting announcements. If you use camera traps for your research, make sure to have a look at the first article, which provides guidelines to individually identify giant armadillos. The short communications include new records of two poorly known species, Cabassous centralis in Guatemala and Dasypus pilosus in Peru. Two contributions deal with behavioral observations, agonistic behavior among Bradypus variegatus and non-agonistic encounters of wild Myrmecophaga tridactyla. Unusual coloring patterns are described in two contributions, one about leucism in Bradypus variegatus and the other about an albino Tamandua tetradactyla.

We're very happy to inform you that our Specialist Group has received a grant from the Species Survival Commission, which allowed us to completely re-design our website www.xenarthrans.org and publish this year's issue of Edentata. You will find additional information on the grant, a summary of a new article on maned sloths, and activities of some of our Specialist Group members in the News section. We are especially proud of our member Sergio Vizcaíno, who received the Outstanding Career Award from the Argentine Society for the Study of Mammals (SAREM). Congratulations, Sergio!

More good news: we have a new Specialist Group member! Rachel Hoffmann was a key member of the SSC Office for 10 years and has been of fundamental help to many Specialist Groups, including the Anteater, Sloth and Armadillo Specialist Group. We're thrilled that she will be supporting us in an advisory role on administrative issues. Thanks for accepting, Rach!

We'd like to give a warm welcome to Alessandra Bertassoni, who has joined the Edentata team as editorial assistant. Welcome to the team, Ale!

Last, but not least, we would like to thank all anonymous reviewers for their excellent work! 


\section{IUCN SSC Anteater, Sloth and Armadillo Specialist Group Members 2017-2020}

Chair

Mariella Superina, Dr.med.vet., Ph.D. in

Conservation Biology

Research Scientist CONICET

Associate Researcher Fundación Omacha

IMBECU, CCT CONICET Mendoza

Casilla de Correos 855

Mendoza (5500)

Argentina

E-mail:mariella@superina.ch

\section{Deputy Chair}

Nádia de Moraes-Barros, Ph.D. in Biology

(Genetics)

Auxiliary Researcher

CiBIO - Centro de Investigação em

Biodiversidade e Recursos Genéticos/InBIO

Laboratório Associado

Universidade do Porto

Campus Agrário de Vairão

Rua Padre Armando Quintas

4485-661 Vairão

Portugal

E-mail:nadiabarros@cibio.up.pt

\section{Red List Authority}

Agustín M. Abba, Doctor in Natural Science

Research Scientist CONICET

Centro de Estudios Parasitológicos y Vectores

(CEPAVE)

CCT - CONICET La Plata - UNLP

Bv. 120 S/N entre Avenida 60 y Calle 64

La Plata (1900)

Argentina

E-mail:abbaam@yahoo.com.ar
Members

Agustín M. Abba, Argentina

Roberto Aguilar, USA

Teresa Cristina Anacleto de Silveira, Brazil

Maria Clara Arteaga, Mexico

Lizette Bermúdez, Peru

Adriano Chiarello, Brazil

Gustavo A.B. da Fonseca, USA

Frédéric Delsuc, France

Flávia Miranda, Brazil

John Gramieri, USA

Jutta Heuer, Germany

Rachel Hoffmann, United Kingdom

Jim Loughry, USA

Colleen McDonough, USA

Dennis A. Meritt Jr., USA

Nadia Moraes-Barros, Brazil/Portugal

Andrew Noss, USA

Tinka Plese, Colombia

Monique Pool, Suriname

Virgilio G. Roig, Argentina

Ilona Schappert, Germany

Diorene Smith, Panama

Paul Smith, Paraguay

Mariella Superina, Argentina

Sergio F. Vizcaíno, Argentina

Bryson Voirin, Germany 


\title{
Guidelines to identify individual giant armadillos, Priodontes maximus (Kerr, 1792), through camera traps
}

\author{
Gabriel Fávero Massocato ${ }^{\mathrm{A}, \mathrm{B}, \mathrm{D}, 1}$ \& Arnaud L.J. Desbiez ${ }^{\mathrm{A}, \mathrm{C}, \mathrm{D}}$ \\ A Instituto de Conservação de Animais Silvestres (ICAS), Rua Afonso Lino Barbosa, 142, Chácara Cachoeira, 79040-290, \\ Campo Grande, Mato Grosso do Sul, Brasil \\ ${ }^{\text {B } H o u s t o n ~ Z o o, ~} 6200$ Hermann Park Drive, Houston, Texas 77030, USA \\ ' Royal Zoological Society of Scotland (RZSS), Murrayfield, Edinburgh, EH12 6TS, United Kingdom \\ ${ }^{D}$ Instituto de Pesquisas Ecológicas (IPÊ), Rodovia Dom Pedro I, km 47, 12960-000, Nazaré Paulista, São Paulo, Brasil \\ ${ }^{1}$ Corresponding author \\ E-mail: gabriel_massocato@hotmail.com
}

\begin{abstract}
Camera trapping is one of the main tools used to advance Priodontes maximus research as it can provide information on the species' presence, densities, relative abundance, home ranges, movement, activity patterns, habitat use, reproduction, and parental care. Photographic records obtained by camera traps allow the individual identification of P. maximus if properly examined. The aim of this work is to provide researchers with the tools to identify individuals of P. maximus in their regions and stimulate further research and conservation work on the species. We use nine years of camera trap work to present and illustrate the different individual identification patterns that can be used to distinguish individuals as well as reproductive status and age class. We describe six different morphological characteristics that can be used for individual identification: cephalic scale pattern, tail markings, light band width and shape above the base of tail, hind limbs, flank scale pattern, and natural marks. Furthermore, we identified two characteristics that can be used to determine sex and age class of individuals. Using these individual identification patterns, a total of 88 P. maximus were individually identified in three areas of Brazil.
\end{abstract}

Keywords: Cerrado savanna, Cingulata, external morphology, individual identification, Pantanal, record

Guia de identificação do tatu-canastra, Priodontes maximus (Kerr, 1792), através de armadilhas fotográficas

Resumo Armadilhas fotográficas são uma das principais ferramentas usadas para avançar nas pesquisas do Priodontes maximus, podendo fornecer informações sobre a presença da espécie, densidades, abundância relativa, áreas de vida, movimento, padrões de atividade, uso de habitat, reprodução e cuidados parentais. Registros fotográficos obtidos pelas armadilhas fotográficas, se forem devidamente examinados, podem permitir a identificação individual do P. maximus. O objetivo deste trabalho é fornecer aos pesquisadores as ferramentas para identificar indivíduos de P. maximus em suas regiões e estimular novos trabalhos de pesquisa e conservação da espécie. Utilizamos nove anos de trabalho com armadilhas fotográficas para apresentar e ilustrar os diferentes padrões de identificação individual que podem ser usados para distinguir indivíduos, assim como o estado reprodutivo e estimar a classe etária. Neste estudo são descritas seis características morfológicas diferentes que podem ser aplicadas para identificação individual (padrão de escamas cefálicas, marcas na cauda, largura e forma da faixa clara acima da base da cauda, membros posteriores, padrão de escamas no flanco e marcas naturais). Além disso, identificamos duas características que podem ser usadas para determinar o sexo e a idade dos indivíduos. Utilizando os padrões descritos por esse estudo, um total de 88 P. maximus foram identificados individualmente em três áreas no Brasil.

Palavras-chave: Cerrado, Cingulata, identificação individual, morfologia externa, Pantanal, registro 


\section{INTRODUCTION}

Camera trapping, the use of remotely triggered cameras that automatically take images of animals passing in front of them, is a widely-used tool to survey and monitor wildlife. Camera traps have been used to assess wildlife distribution, abundance, behavior, and community structure (Rovero \& Zimmermann, 2016). Furthermore, technological advances in infrared sensors and digital photography have led to cost-effective, non-invasive means of generating reliable information on elusive wildlife (Kucera \& Barrett, 2011). Camera traps reduce disturbance, as units can be left unattended for weeks or months, and are therefore particularly well suited for monitoring and identifying elusive, cryptic species with low densities in remote areas (Long et al., 2008).

The giant armadillo (Priodontes maximus) is the largest representative of the order Cingulata. It can reach $150 \mathrm{~cm}$ in body length and weigh up to $50 \mathrm{~kg}$ (Carter et al., 2016; Desbiez et al., 2019b). Despite a wide distribution throughout South America, P. maximus is always rare (Meritt, 2006). In addition to low densities, the species is solitary, nocturnal and has fossorial habits, making it particularly difficult to capture and study in the wild (Desbiez et al., 2019c). For this reason, camera traps have always been a very important tool in $P$. maximus research (Leite-Pitman et al., 2004; Noss et al., 2004; Silveira et al., 2009; Porfirio et al., 2012; Desbiez \& Kluyber, 2013; Aya-Cuero et al., 2015, 2017; Massocato \& Desbiez, 2017; Quiroga et al., 2017; Esteves et al., 2018; Desbiez et al., 2019a, c).

Noss et al. (2004) were the first to use individual identification for camera trap records of $P$. maximus. The authors describe using "the dividing line between dark and light scales on the carapace and on the hind legs" as well as "the number of light scales per row from the lower edge of the carapace up to the dividing line" (Noss et al., 2004:47) to identify individuals. All later researchers using individual identification of $P$. maximus cite this publication, sometimes adding another identifying characteristic such as scars (Aya-Cuero et al., 2017) or the scales on the tail (Desbiez et al., 2019c). The purpose of this study is to clearly present and illustrate the different individual identification patterns that can be used in camera trap research to distinguish individual $P$. maximus as well as to assess their reproductive status and age class.

\section{MATERIALS AND METHODS}

Our work is based on nine years of camera trapping in three different study areas in Mato Grosso do Sul state, Midwestern Brazil. All records are from Reconyx camera traps (HC-500, HC-550, HC-600, and PC-850; Reconyx, Holmen, USA) set to rapid fire mode, recording three to ten consecutive photos without any intervals.

Site 1: Pantanal. July 2010 to September 2019 in an area of $350 \mathrm{~km}^{2}$ in the Brazilian Pantanal (Nhecolândia sub-region; $19^{\circ} 16^{\prime} 60^{\prime \prime S}, 55^{\circ} 42^{\prime} 60^{\prime \prime} \mathrm{W}$ ). We installed camera traps laterally to the entrance of burrows used by animals monitored with transmitters. Cameras were used to document the animals' health (weight loss, lesions or injuries), other species visiting the burrow, and potential transient animals $(8,110$ camera trap/nights $)$. Furthermore, cameras were also set in a $100 \mathrm{~km}^{2}$ grid within the study area where the monitored armadillos were known to be active (4,500 camera trap/nights).

Site 2: Cisalpina. September 2014 to February 2018 in an area of $30 \mathrm{~km}^{2}$ in the Cerrado of Eastern Mato Grosso do Sul state, Brazil (2116'03"S, $\left.51^{\circ} 54^{\prime} 96^{\prime \prime W}\right)$. We installed camera traps laterally to the $P$. maximus burrow entrances to document visitors, in front of feeding excavations, and on trails (4,060 camera trap/nights).

Site 3: MS-040. April 2018 to October 2018 in an area of $360 \mathrm{~km}^{2}$ in the Cerrado in the center of Mato Grosso do Sul state, Brazil (21 $06^{\circ} 27^{\prime \prime S}$, $\left.53^{\circ} 52^{\prime} 00^{\prime \prime} \mathrm{W}\right)$. We positioned camera traps primarily to detect giant anteaters (Myrmecophaga tridactyla) along fences, river banks, old roads, trails, as well as in open areas and occasionally in front of the entrance of burrows $(5,132$ camera trap/nights $)$.

Images of individual patterns used to identify $P$. maximus were selected and classified to create guidelines to help other researchers to distinguish between individual $P$. maximus as well as to assess their reproductive status and age class.

\section{RESULTS}

A total of 50 P. maximus were identified at Site 1 using both data sets from the study area: 28 females, 21 males, and one individual we were unable to individually identify. At Site 2, a total of four P. maximus were identified: three adult females and one juvenile male. At Site 3, a total of 15 P. maximus were identified including seven adult females, seven adult males, and one juvenile female. We also recorded 19 adults that we were unable to individually identify.

Six morphological characteristics that can be used for individual identification were identified and used to distinguish P. maximus from each other. The use of each of these patterns depends on the position of the animal and the angle of the camera. Not all patterns are visible on a single picture, but usually several characteristics can be recorded and later used to confirm if the same animal is photographed again. 


\section{Individual identification patterns}

Cephalic scale pattern. The pattern of scales displayed on the animal's head is unique. These scales are large and easily distinguished; they also vary in shape, number, and arrangement. However, this requires a frontal image, which is unlikely if the animal is walking on a trail perpendicular to the camera. This image is easier to obtain when the camera is placed near a burrow or feeding excavation (FIG. 1).

Tail markings. Priodontes maximus individuals may have dark scales along the tail interspersed among the lighter scales. When present, these dark scales may vary in number and arrangement along the tail. Some individuals have multiple dark scales that are easy to distinguish and facilitate identification. In general, these dark scales originate at the base of the tail and are present on its dorsal portion (FIG. 2).

Light band width and shape above the base of tail. The width and shape of the light band between the base of the tail and the darker scales at the upper part of the carapace can be a useful pattern for identifying individuals. Some animals have a thin or thick light band, depending on how close the dark scales from the top of the carapace are to the base of the tail. The intersection between the dark and light scales can be formed by round to pointed scales, which are also unique and a good characteristic to examine when identifying individuals. This pattern is commonly visible in photos of animals entering their burrows (FIG. 3).

Hind limbs. Some individuals have a dark ankle brace on the upper hind limb that may be of varying shape or size on each side or even absent in some individuals. This is usually easy to distinguish but one must be cautious of soil masking the markings (FIG. 4). The shape, size or absence of the ankle brace is different on each hind limb.

Flank scale pattern. Only one of the flanks of P. maximus is recorded in a single photograph and the patterns can be different for each side of an individual. It is therefore important to note the side for which a pattern is being identified. For the flanks, identification patterns are comprised of the number of light scales between the edge of the carapace and the dark scales, as well as indentations and shapes formed by the light and dark scales (FIGS. 5, 6, 7). For identification purposes, the flanks of the animal are divided in three areas: anterior, medial, and posterior. The anterior area comprises the scale pattern on the laterals of the scapular portion of the carapace (above the front foot, ending before the first flexible band; FIG. 5). The medial area is comprised of flexible bands in the middle of the animal's body (FIG. 6). The posterior area covers the area of the pelvic portion of the carapace (after the last flexible band; FIG. 7).

Natural marks. Some animals may have striking morphological features, such as scars on the armor or scale color variation (i.e., a dark scale in the light band or a patch of light scales on the dark armor). However, this characteristic may be difficult to assess, especially when evaluating black and white camera images, as scars or dark patches sometimes result from soil stuck on the armor (FIG. 8).

\section{Identification of sex, age class, and reproductive status}

Desbiez et al. (2019b) report that morphometric differentiation between sexes is possible through the association of three morphological parameters (carapace length, thorax circumference, and hind limb length) and that adult males are larger and heavier than females. Silveira et al. (2012) also found significant sex differences in mean body measurements in seven out of the 14 parameters recorded. In camera traps, at first glance it seems impossible to distinguish between male and female P. maximus. However, upon careful examination and depending on the angle, sex, reproductive status, and age class can be identified and/or estimated.

Females. Adult female P. maximus present a visible elongated vulva that measures about $7 \mathrm{~cm}$, while the vulva of younger females will be smaller and harder to detect (Desbiez et al., 2019b). Visible teats, located high up in the thoracic region almost under the armpits, were measured during anesthesia procedures in Site 1. They can be more than $2.5 \mathrm{~cm}$ long when a female has been through at least one lactation period. A nulliparous female will have teats that are about $1 \mathrm{~cm}$ long (FIG. 9). Finally, if a female is nursing, the area around the teat will be lighter in color, since the dirt is constantly removed from this area when the young is suckling (FIG. 10).

Males. The size of the reproductive organ of male P. maximus can allow the observer to evaluate its reproductive stage. As illustrated in FIG. 11, there is a visible difference between reproductive adult males and younger sub-adult males (Desbiez et al., 2019b).

Based on these eight characteristics, a total of 88 P. maximus were individually identified in all of our study areas.

\section{Discussion}

Camera trapping has been one of the key tools used to advance P. maximus research. This technique has provided information on species presence (Porfirio et al., 2012; Massocato \& Desbiez, 2017; Quiroga et al., 2017; Esteves et al., 2018), density (Noss et al., 2004; Silveira et al., 2009; Aya-Cuero et al., 
2017), relative abundance (Quiroga et al., 2017), home range and movement (Noss et al., 2004), activity patterns (Silveira et al., 2009; Aya-Cuero et al., 2017), habitat use (Aya-Cuero et al., 2017), reproduction, and parental care (Aya-Cuero et al., 2015; Desbiez et al., 2019a).

Individual identification of $P$. maximus can be challenging, especially when analyzing camera trap data from a rapid survey or from studies designed for other species (e.g., large felids, such as jaguars). For example, camera traps set in Site 3 were placed to capture images of $M$. tridactyla rather than $P$. maximus, and cameras were only maintained in the same area for, on average, 30 days. Despite the experience of the authors, less than half of $P$. maximus recorded could be individually identified. Nevertheless, the proportion of positive identifications can be increased by taking into account some recommendations, which we will list below.

In the Pantanal, 50 P. maximus have been individually identified. This was a species-specific longterm study, which means that cameras were placed purposely in locations where P. maximus would stop, such as excavations or termite mounds. Cameras were also maintained in the same area for long periods of time (at least over a year). In addition, 30 of the animals have been captured and were registered and photographed at different angles while under anesthesia. For this reason, even pictures showing few details or low quality images could render a positive individual identification.

To increase the chances of identifying individual P. maximus, cameras with high resolution must be used (Newey et al., 2015) and strategically placed. The best photographs can be obtained by placing the camera near evidences of $P$. maximus, such as sleeping burrows, feeding excavations or even a termite mound with recent signs of predation. At these locations, the animals pause to seek olfactory clues, which increases the chances that photographs will capture details of scale patterns. Very often images captured on trails are blurry because the animals are moving.

It is often helpful to use a combination of morphological clues to ascertain an individual's identity. Maintaining cameras in the same area for a prolonged amount of time (more than six months) allows to take several images of an animal, ensuring various angles of the same individual are captured, which facilitates its identification. When camera traps are placed near excavations, it is best to do so on the side, rather than in front, as it prevents the camera from being covered with soil in case the animal excavates the burrow again. Additionally, it is best to always place the cameras on one specific side of the excavation so that the same flank will be captured, thus facilitating the identification of the animals.
The purpose of this article was not to discuss study designs or analysis methods, but rather to provide the tools so that researchers have a better chance to distinguish individual $P$. maximus recorded by their camera traps. Furthermore, the identification illustrations and suggestions proposed here may be extended and adapted to other armadillo species. We hope the figures will help researchers to identify individuals in their study regions and stimulate further research and conservation work on P. maximus.

\section{ACKNOWLEDGEMENTS}

We thank the owners of the 43 ranches in the Nhecolândia region of the Pantanal and near the MS-040 in the Cerrado as well as RPPN Cisalpina for their hospitality, and for permission to work on their lands. We are grateful to Vinícius Alberici, Danilo Kluyber, and the numerous project volunteers for their help in the field. We also thank Andrew Noss, Nina Attias, Mariella Superina, and an anonymous reviewer for their helpful comments. This study is part of the Giant Armadillo Conservation Program that receives funding from many different partners, mostly from zoos in North America and Europe listed at www.giantarmadillo.org.

\section{REFERENCES}

Aya-Cuero, C., A. Rodríguez-Bolaños \& M. Superina. 2017. Population density, activity patterns, and ecological importance of giant armadillos (Priodontes maximus) in Colombia. Journal of Mammalogy 98: 770-778. https://doi.org/10.1093/jmammal/gyx006

Aya-Cuero, C., M. Superina \& A. Rodríguez-Bolaños. 2015. Primeros registros de crías de ocarro (Priodontes maximus Kerr, 1792) en Colombia. Edentata 16: 57-64.

Carter, T.S., M. Superina \& D. M. Leslie. 2016. Priodontes maximus (Cingulata: Chlamyphoridae). Mammalian Species 48: 21-34.https://doi.org/10.1093/mspecies/ sew002

Desbiez, A.L.J. \& D. Kluyber. 2013. The role of giant armadillos (Priodontes maximus) as physical ecosystem engineers. Biotropica 45: 537-540. https://doi. org/10.1111/btp.12052

Desbiez, A.L.J., G.F. Massocato \& D. Kluyber. 2019a. Insights into giant armadillo (Priodontes maximus Kerr, 1792) reproduction. Mammalia. https://doi. org/10.1515/mammalia-2019-0018

Desbiez, A.L.J., G.F. Massocato, D. Kluyber, C.N. Luba \& N. Attias. 2019b. How giant are giant armadillos? The morphometry of giant armadillos (Priodontes maximus Kerr, 1792) in the Pantanal of Brazil. Mammalian Biology 95: 9-14. https://doi.org/10.1016/j. mambio.2018.12.007

Desbiez, A.L.J., G.F. Massocato, D. Kluyber, L.G.R., Oliveira-Santos \& N. Attias. 2019c. Spatial ecology of the giant armadillo (Priodontes maximus) in Mid- 
western Brazil. Journal of Mammalogy. https://doi. org/10.1093/jmammal/gyz172

Esteves, C.F., D.H. Homem, R. Bernardo \& E.F. Lima. 2018. Notes on giant armadillo Priodontes maximus (Cingulata: Chlamyphoridae) distribution and ecology in Eucalyptus plantation landscapes in eastern Mato Grosso do Sul State, Brazil. Edentata 19: 47-56. https://doi.org/10.2305/IUCN.CH.2018.Edentata19-1.6.en

Kucera, T.E. \& R.H. Barrett. 2011. A history of camera trapping. Pp. 9-26 in: Camera traps in animal ecology (A.F. O'Connell, J.D. Nichols \& K.U. Karanth, eds.). Springer, New York. https://doi.org/10.1007/ 978-4-431-99495-4_2

Leite-Pitman, R. et al. 2004. Habitat use and activity of the giant armadillo (Priodontes maximus): Preliminary data from southeastern Peru. Presented at the Society for Conservation Biology Meeting, New York, USA.

Long, R.A., P. MacKay, J.C. Ray \& W.J. Zielinski. 2008. Non-invasive survey methods for carnivores. Island Press, Washington and London. 385 pp.

Massocato, G.F \& A.L.J. Desbiez. 2017. Presença e importância do tatu-canastra, Priodontes maximus (Kerr, 1792), na maior área protegida do leste do Estado de Mato Grosso do Sul, Brasil. Edentata 18: 26-33. https://doi.org/10.2305/IUCN.CH.2017.Edentata18-1.4.en
Meritt, D.A. Jr. 2006. Research questions on the behavior and ecology of the giant armadillo (Priodontes maximus). Edentata 7: 30-33. https://doi. org/10.1896/1413-4411.7.1.30

Newey, S. et al. 2015. Limitation of recreational camera traps for wildlife management and conservation research: A practitioner's perspective. Ambio 44: 624635. https://doi.org/10.1007/s13280-015-0713-1

Noss, A.J., R. Peña \& D. I. Rumiz. 2004. Camera trapping Priodontes maximus in the dry forests of Santa Cruz, Bolivia. Endangered Species Update 2: 43-52.

Porfirio, G.E.O. et al. 2012. New records of giant armadillo Priodontes maximus (Cingulata: Dasypodidae) at Serra do Amolar, Pantanal of Brazil. Edentata 13: 72-75. https://doi.org/10.5537/020.013.0110

Quiroga, V.A., Y.E. Di Blanco, A. Noss, A.J. Paviolo \& M.S. Di Bitetti. 2017. The giant armadillo (Priodontes maximus) in the Argentine Chaco. Mastozoología Neotropical 24: 163-175.

Rovero, F. \& F. Zimmermann. 2016. Camera trapping for wildlife research. Pelagic Publishing, United Kingdom. 293 pp.

Silveira, L., A.T.A. Jácomo, M.M. Furtado, N.M. Torres, R. Sollmann \& C. Vynne. 2009. Ecology of the giant armadillo (Priodontes maximus) in the grasslands of central Brazil. Edentata 8-10: 25-34. https://doi. org/10.1896/020.010.0112

Received: 25 November 2019; Accepted: 29 November 2019 


\section{FIGURES}

Cephalic scale pattern. The pattern of scales displayed on the animal's head is unique. These scales are large and easily distinguished; they also vary in shape, number, and arrangement. However, this requires a frontal image, which is unlikely if the animal is walking on a trail perpendicular to the camera. This image is easier to obtain when the camera is placed near a burrow or feeding excavation.
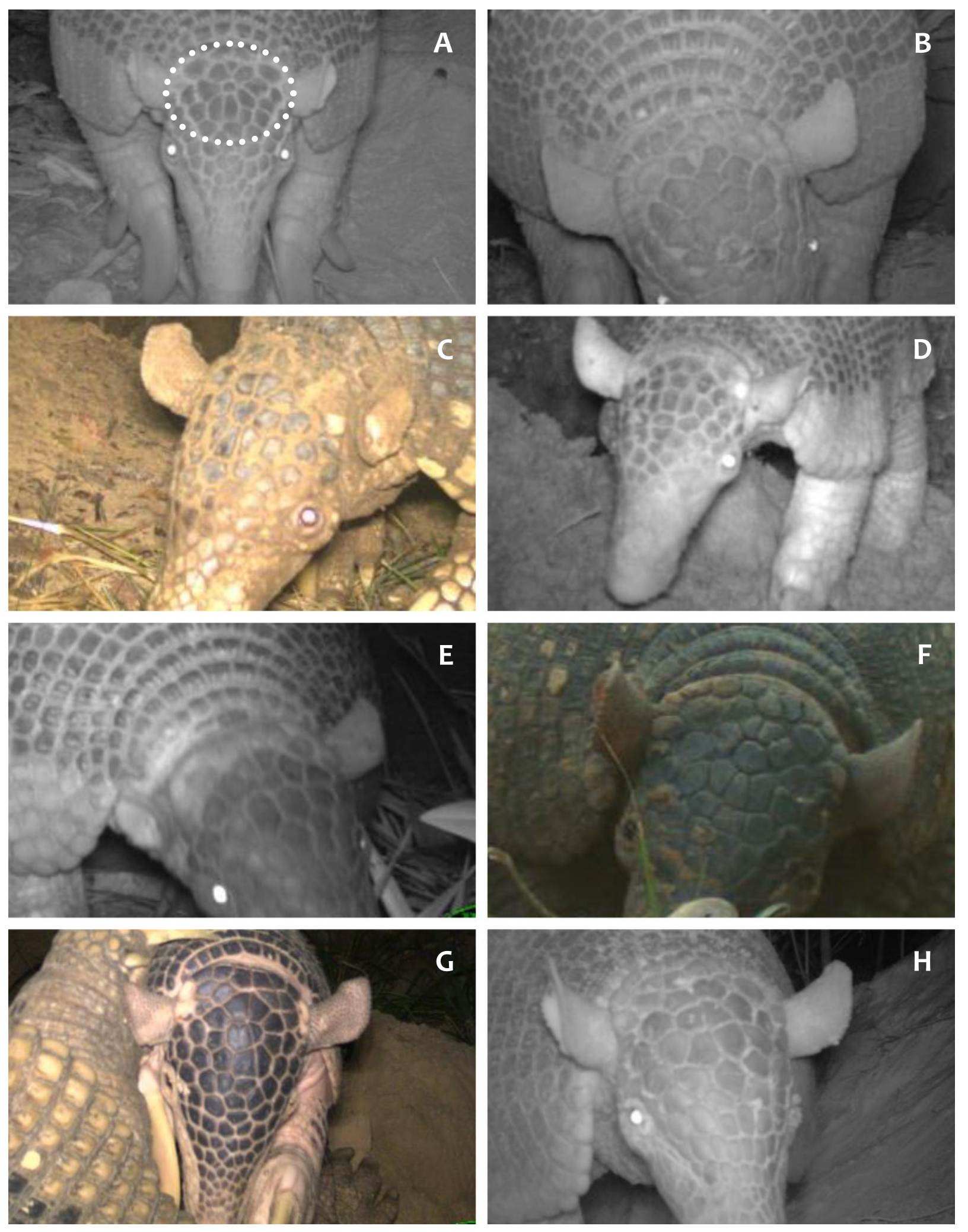

FIGURE 1. Individual scale pattern on the cephalic shield of giant armadillos (Priodontes maximus). (A) Region of the head to be evaluated for individual identification patterns. (B-H) Examples of variation in cephalic shield scale pattern. 
Tail markings. Priodontes maximus individuals may have dark scales along the tail interspersed among the lighter scales. When present, these dark scales may vary in number and arrangement along the tail. Some individuals have multiple dark scales that are easy to distinguish and facilitate identification. In general, these dark scales originate at the base of the tail and are present on its dorsal portion.
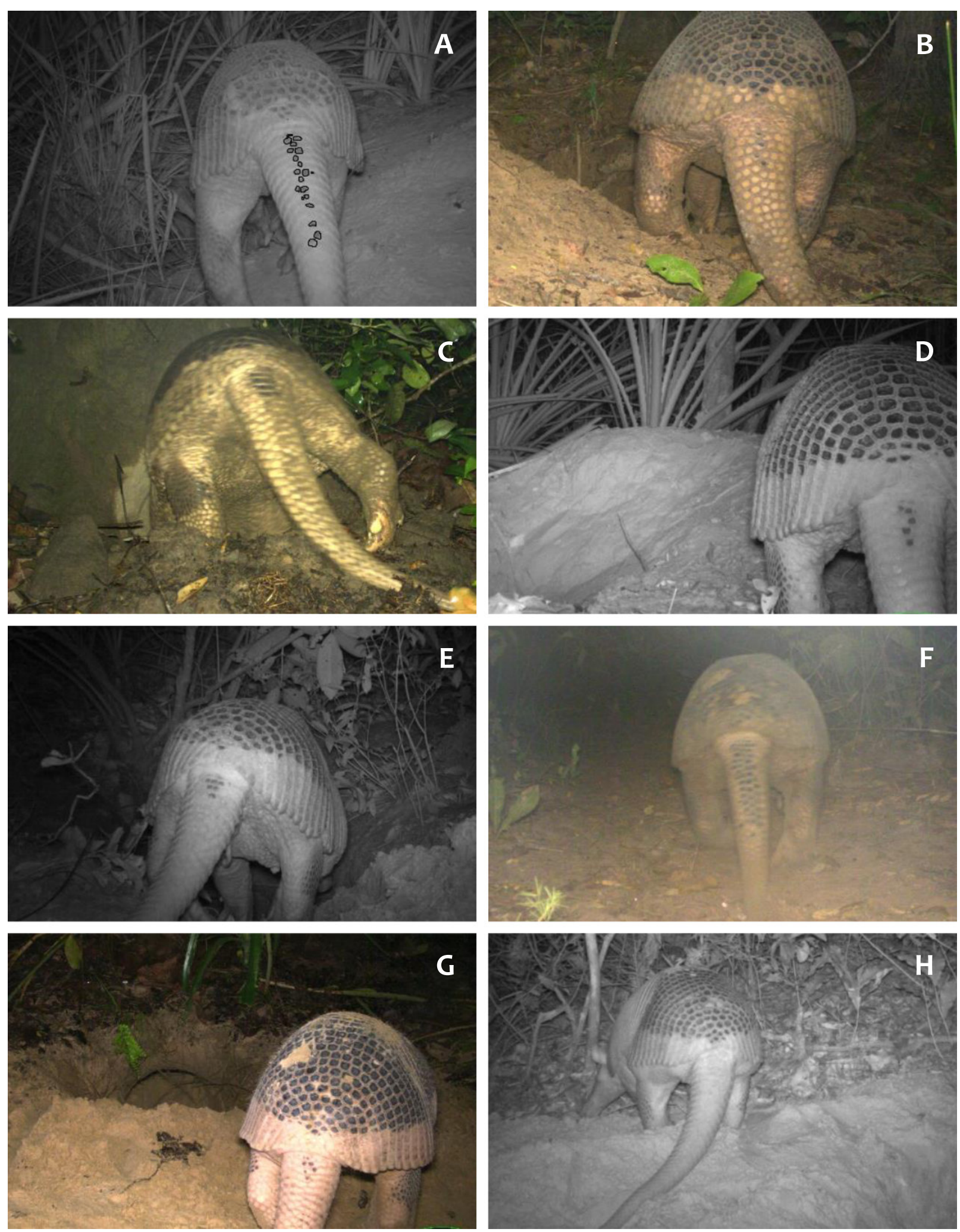

FIGURE 2. Individual scale pattern on the tail of giant armadillos (P. maximus). (A) Region of the tail to be evaluated for individual identification patterns. (B-F) Examples of variation in tail scale pattern. (H) Example of absence of dark scales along the tail. 
Light band width and shape above the base of tail. The width and shape of the light band between the base of the tail and the darker scales at the upper part of the carapace can be a useful pattern for identifying individuals. Some animals have a thin or thick light band, depending on how close the dark scales from the top of the carapace are to the base of the tail. The intersection between the dark and light scales can be formed by round to pointed scales, which are also unique and a good characteristic to examine when identifying individuals. This pattern is commonly visible in photos of animals entering their burrows.

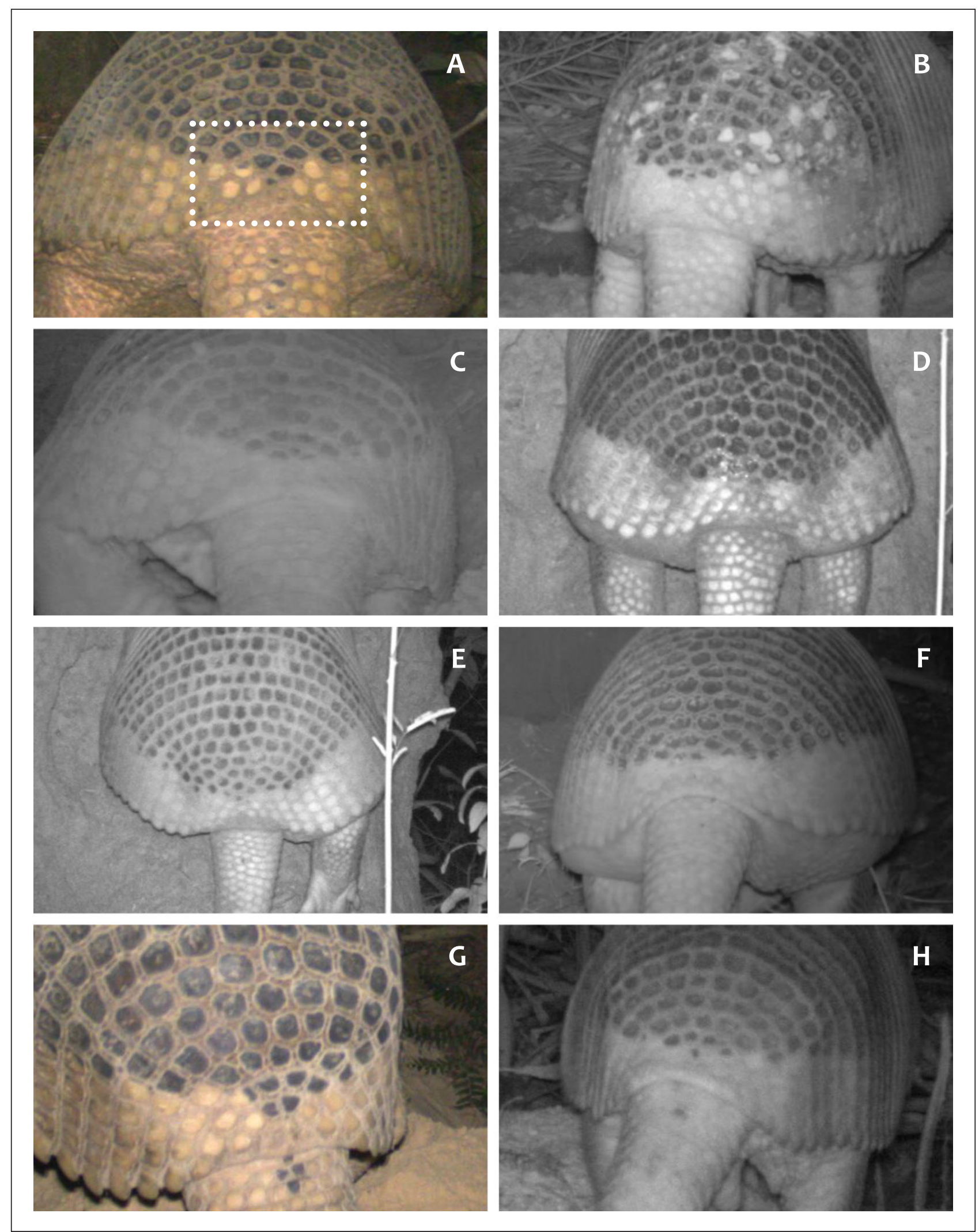

FIGURE 3. Individual scale pattern of light band width and shape above the base of the tail of giant armadillos (P. maximus). (A) Region of the base of the tail to be evaluated for individual identification patterns. (B-H) Examples of pattern variation on the light band width and shape above the base of the tail. 
Hind limbs. Some individuals have a dark ankle brace on the upper hind limb that may be of varying shape or size on each side or even absent in some individuals. This is usually easy to distinguish but one must be cautious of soil masking the markings. The shape, size or absence of the ankle brace is different on each hind limb.

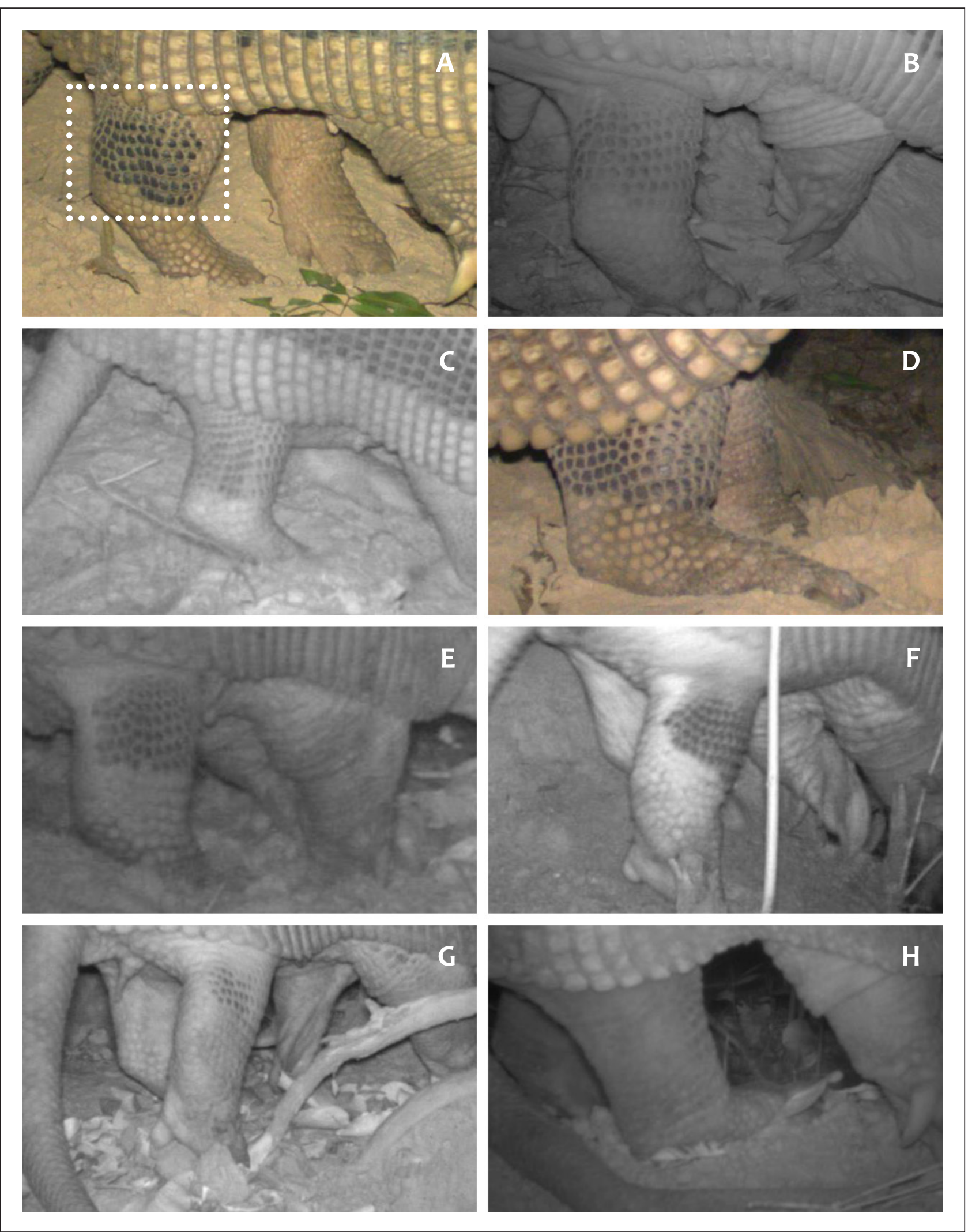

FIGURE 4. Individual scale pattern on the hind limb of giant armadillos (P. maximus). (A) Region of the hind limb to be evaluated for individual identification patterns. (B-F) Examples of variation in hind limb scale pattern. (H) Example of absence of dark scales along the hind limb. 
Flank scale pattern. Only one of the flanks of P. maximus is recorded in a single photograph and the patterns can be different for each side of an individual. It is therefore important to note the side for which a pattern is being identified. For the flanks, identification patterns are comprised of the number of light scales between the edge of the carapace and the dark scales, as well as indentations and shapes formed by the light and dark scales (FIGS. 5, 6, 7). For identification purposes, the flanks of the animal are divided in three areas: anterior, medial, and posterior. The anterior area comprises the scale pattern on the laterals of the scapular portion of the carapace (above the front foot, ending before the first flexible band).

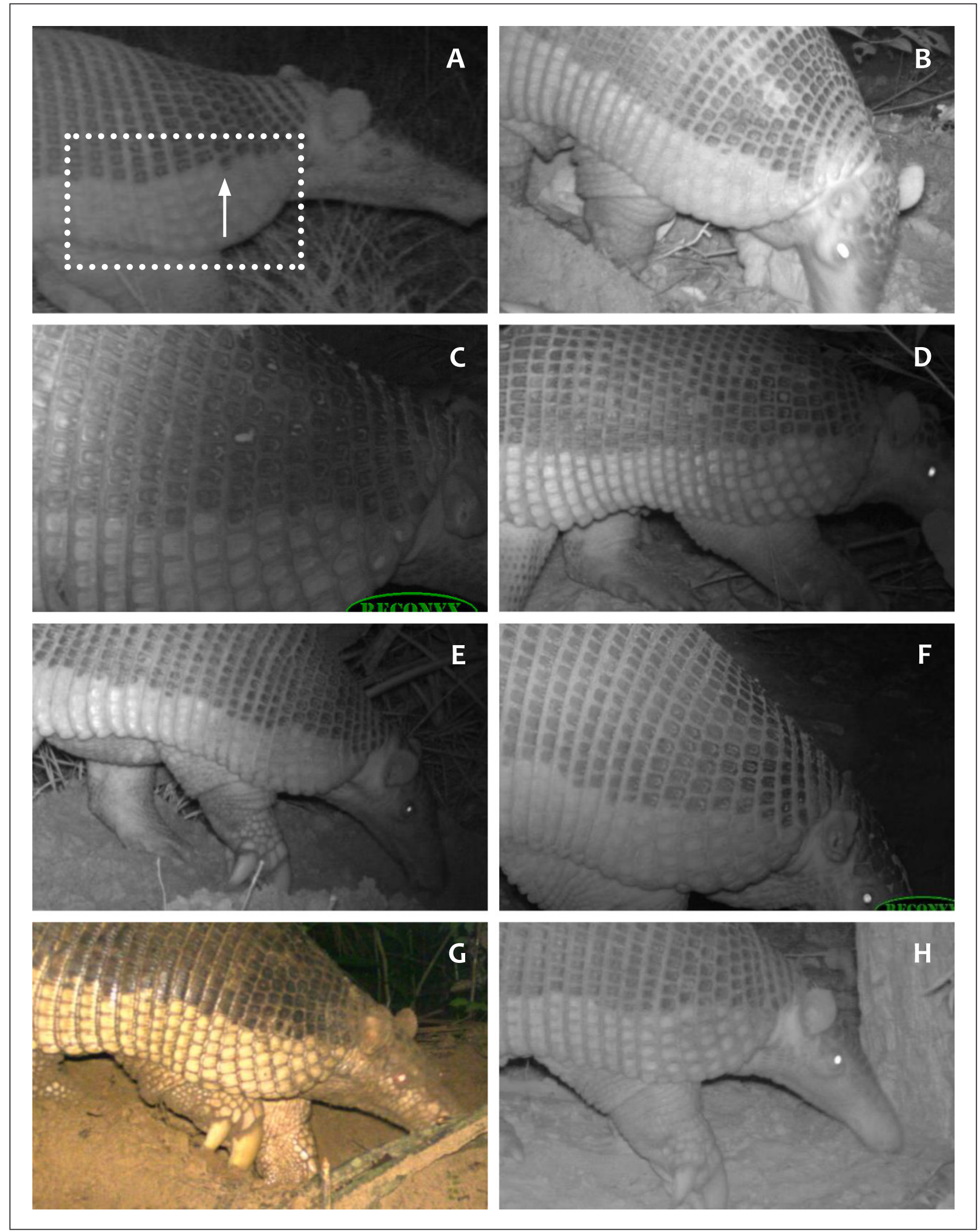

FIGURE 5. The prominent dark scale pattern between the light band and dark scales from the section of the armor of giant armadillos (P. maximus) above the front leg to the area where the flexible bands start. (A) Region of the anterior section to be evaluated for individual identification patterns. (B-H) Examples. 
Flank scale pattern. The medial area is comprised of flexible bands in the middle of the animal's body.

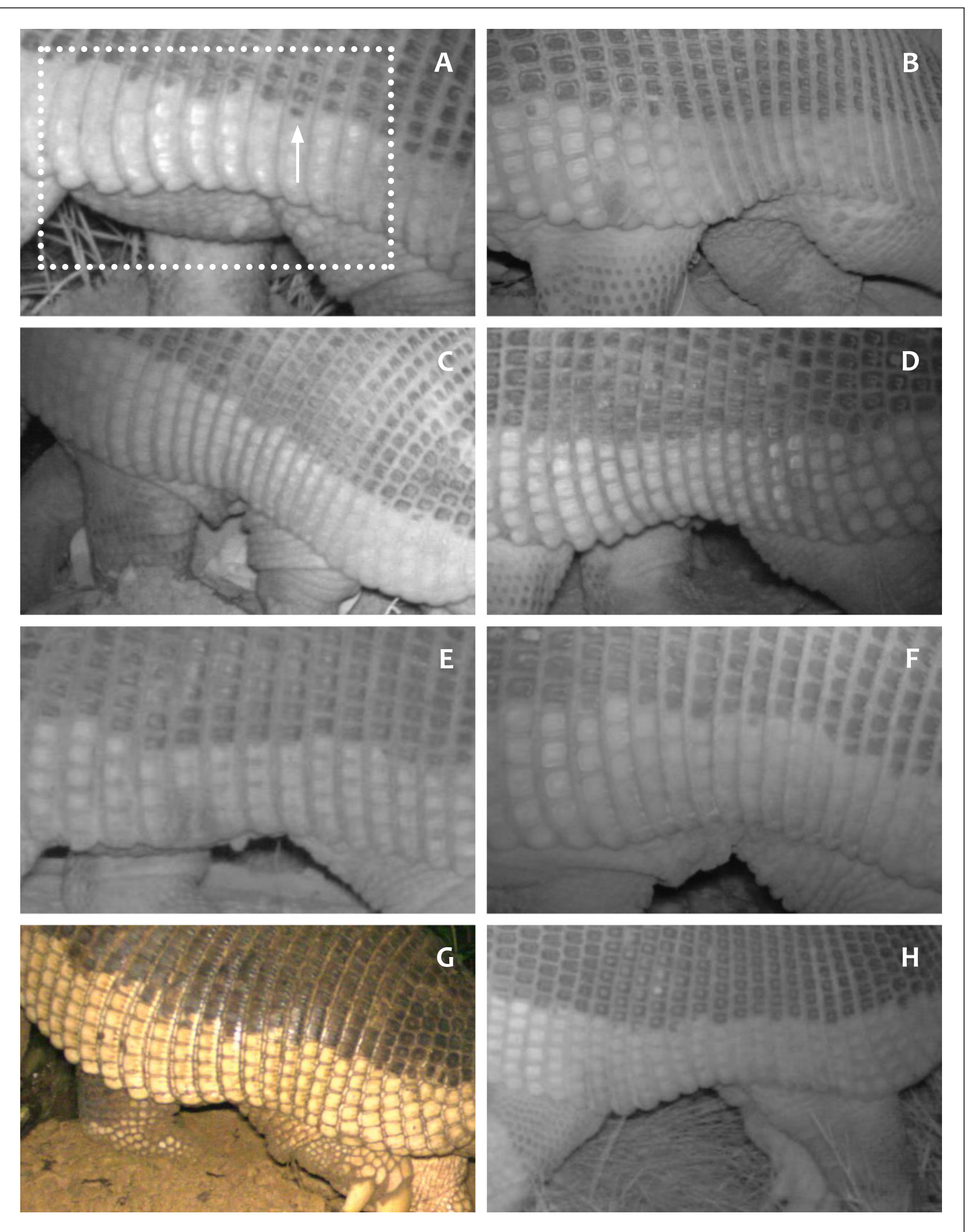

FIGURE 6. Medial individual scale pattern on the carapace of giant armadillos (P. maximus). (A) Region of the medial section to be evaluated for individual identification patterns. (B-H) The prominent dark scale pattern comprises the flexible bands in the central part of the animal's carapace. 
Flank scale pattern. The posterior area covers the area of the pelvic portion of the carapace (after the last flexible band).
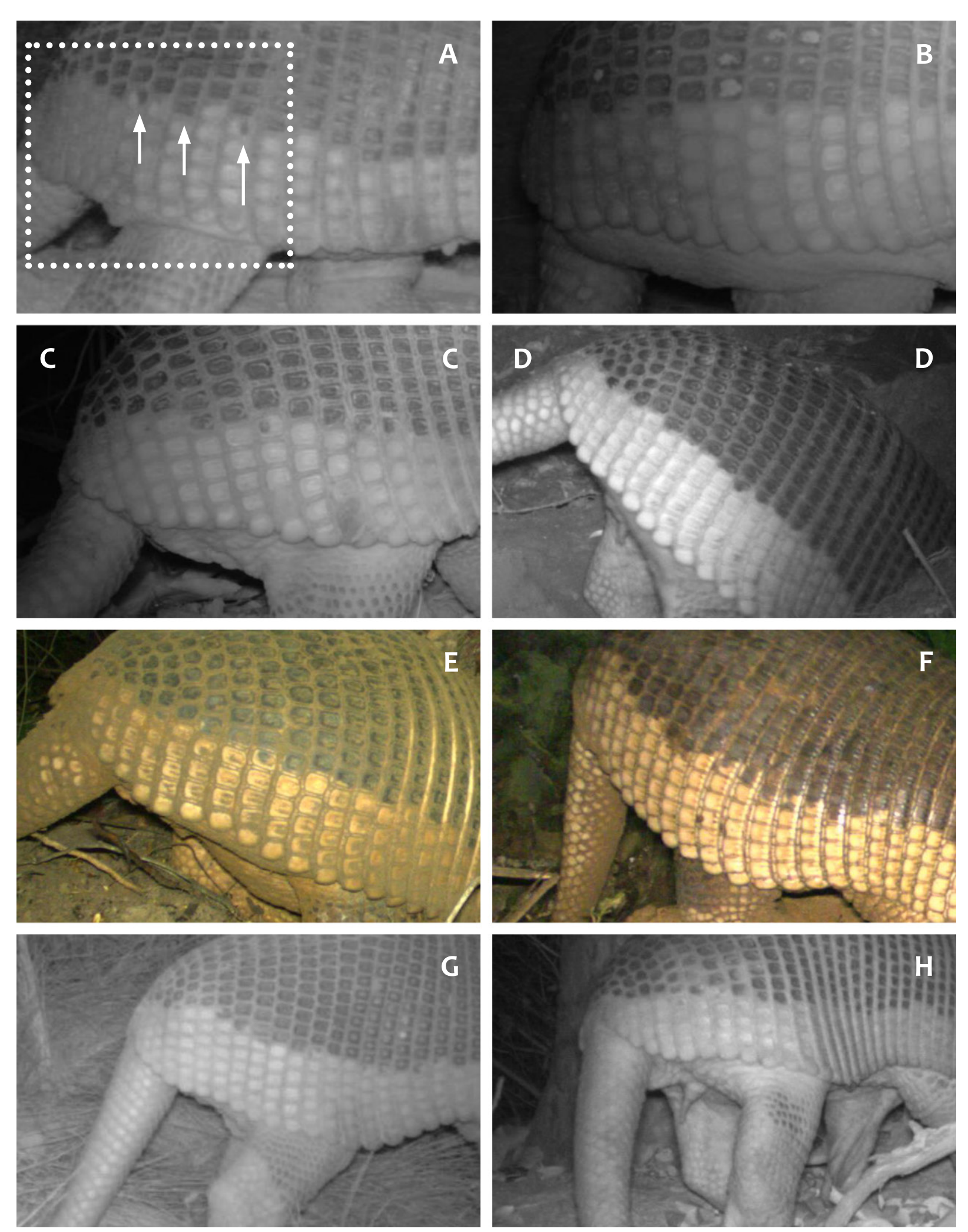

FIGURE 7. Individual scale pattern of the giant armadillo (P. maximus), after the last flexible band to the base of the tail. (A) Region of the posterior section to be evaluated for individual identification patterns. (B-H) Examples of the prominent dark scales after the last flexible band. 
Natural marks. Some animals may have striking morphological features, such as scars on the armor or scale color variation (i.e., a dark scale in the light band or a patch of light scales on the dark armor). However, this characteristic may be difficult to assess, especially when evaluating black and white camera images, as scars or dark patches sometimes result from soil stuck on the armor.

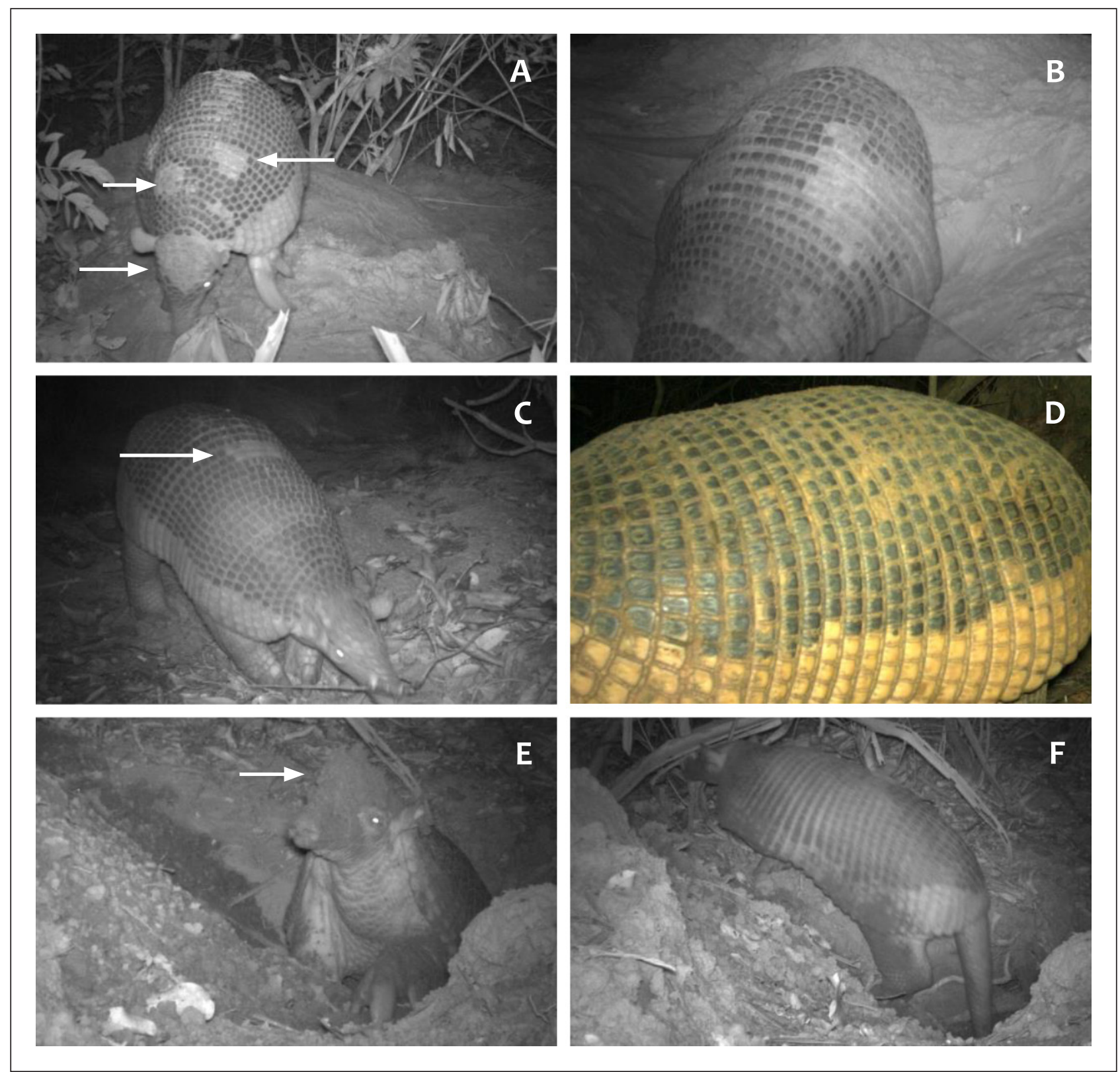

FIGURE 8. Natural marks on the scale pattern of giant armadillos (P. maximus). (A-B) Region of the scars to be evaluated for individual identification patterns. (C-D) Region of the scales of the opposite color range. (E-F) Example of wet soil stuck on the armor, covering the scars or light patches. 
Females. Adult female P. maximus present a visible elongated vulva that measures about $7 \mathrm{~cm}$, while the vulva of younger females will be smaller and harder to detect (Desbiez et al., 2019b). Visible teats, located high up in the thoracic region almost under the armpits, were measured during anesthesia procedures in Site 1. They can be more than $2.5 \mathrm{~cm}$ long when a female has been through at least one lactation period. A nulliparous female will have teats that are about $1 \mathrm{~cm}$ long.
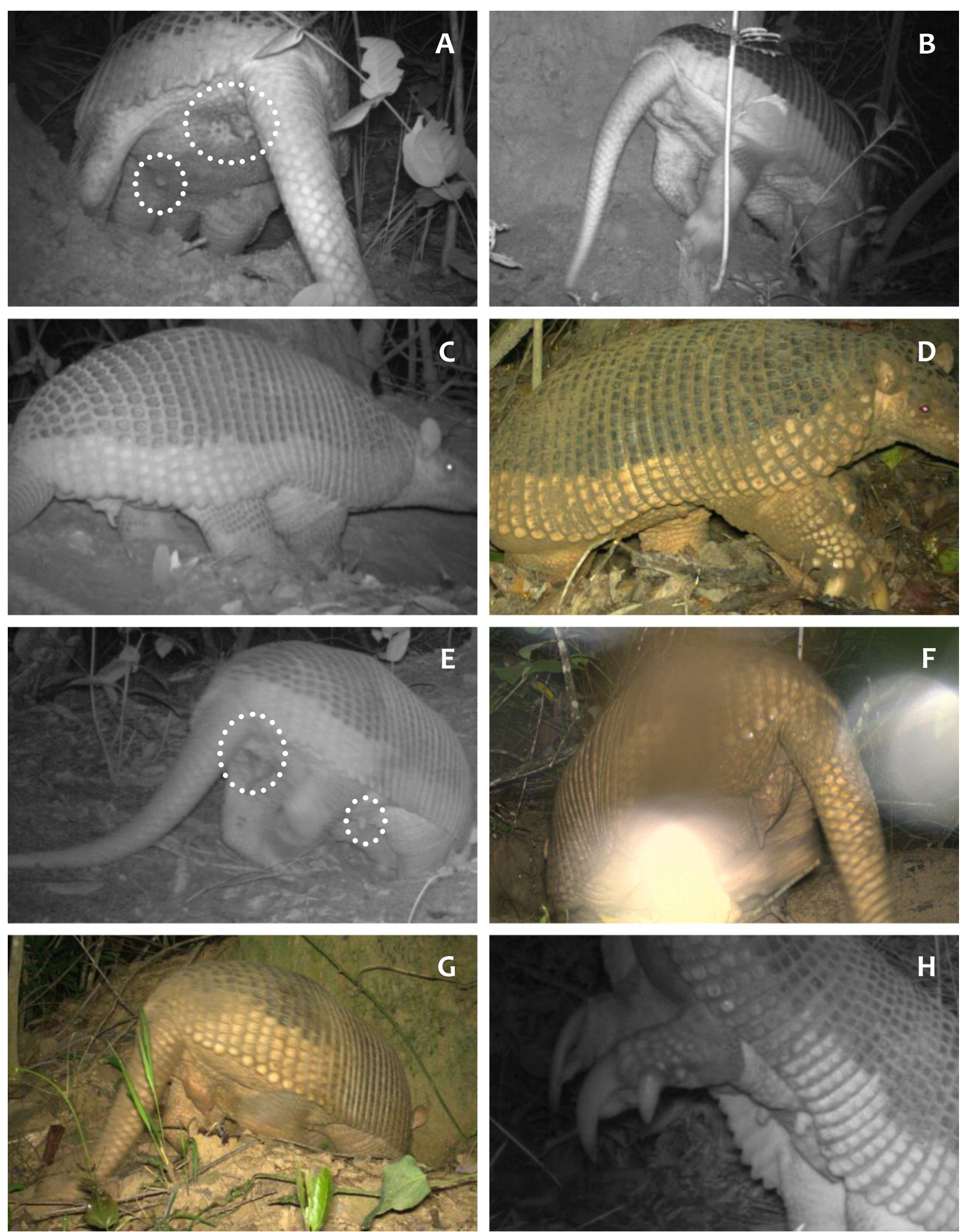

FIGURE 9. Sex and age class identification in female giant armadillos (P. maximus) (A) Region to be evaluated for identification patterns. (B-D) The smaller and harder to detect vulva and teats in young females. (E) Region to be evaluated for identification patterns. (F-H) Visible elongated vulva and developed teats of adult and reproductive female. 
Females. Finally, if a female is nursing, the area around the teat will be lighter in color, since the dirt is constantly removed from this area when the young is suckling.

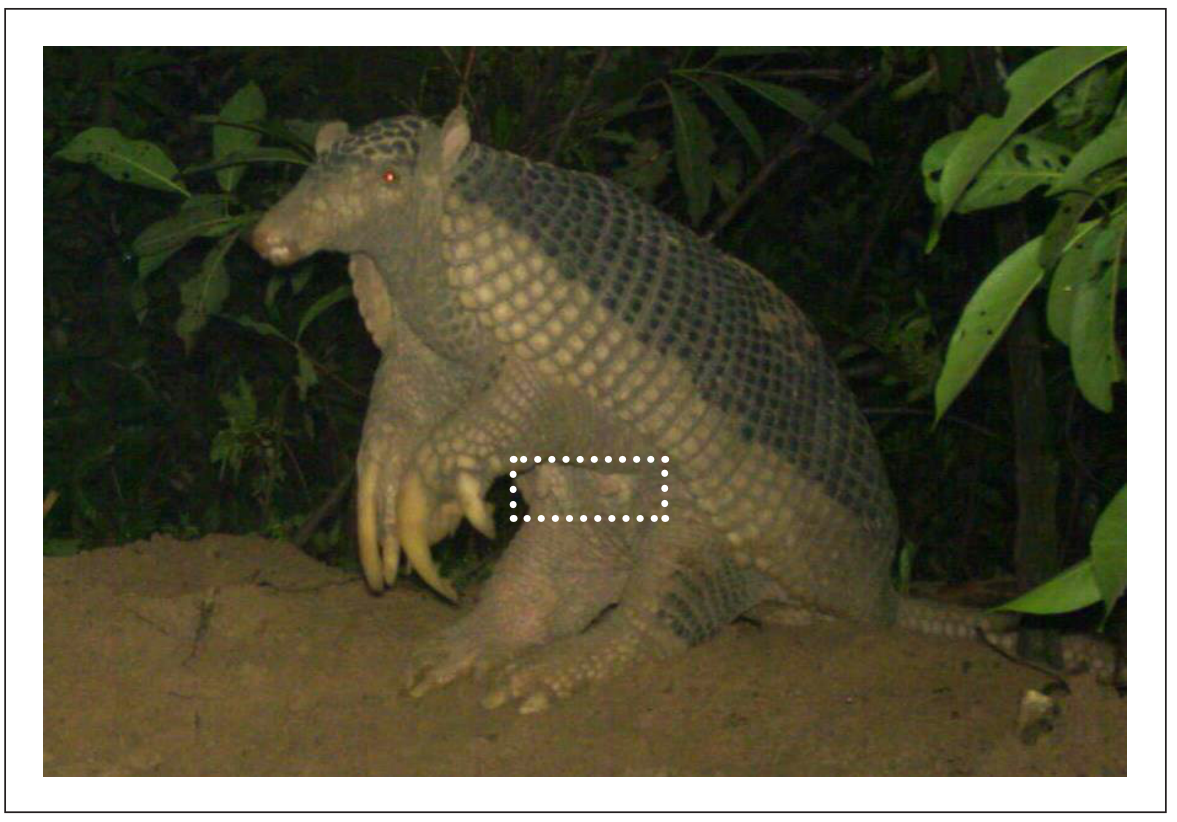

FIGURE 10. The area around the teats is lighter in color, evidencing that the female giant armadillo (P. maximus) is nursing. 
Males. The size of the reproductive organ of male P. maximus can allow the observer to evaluate its reproductive stage. As illustrated in this figure, there is a visible difference between reproductive adult males and younger sub-adult males (Desbiez et al., 2019b).
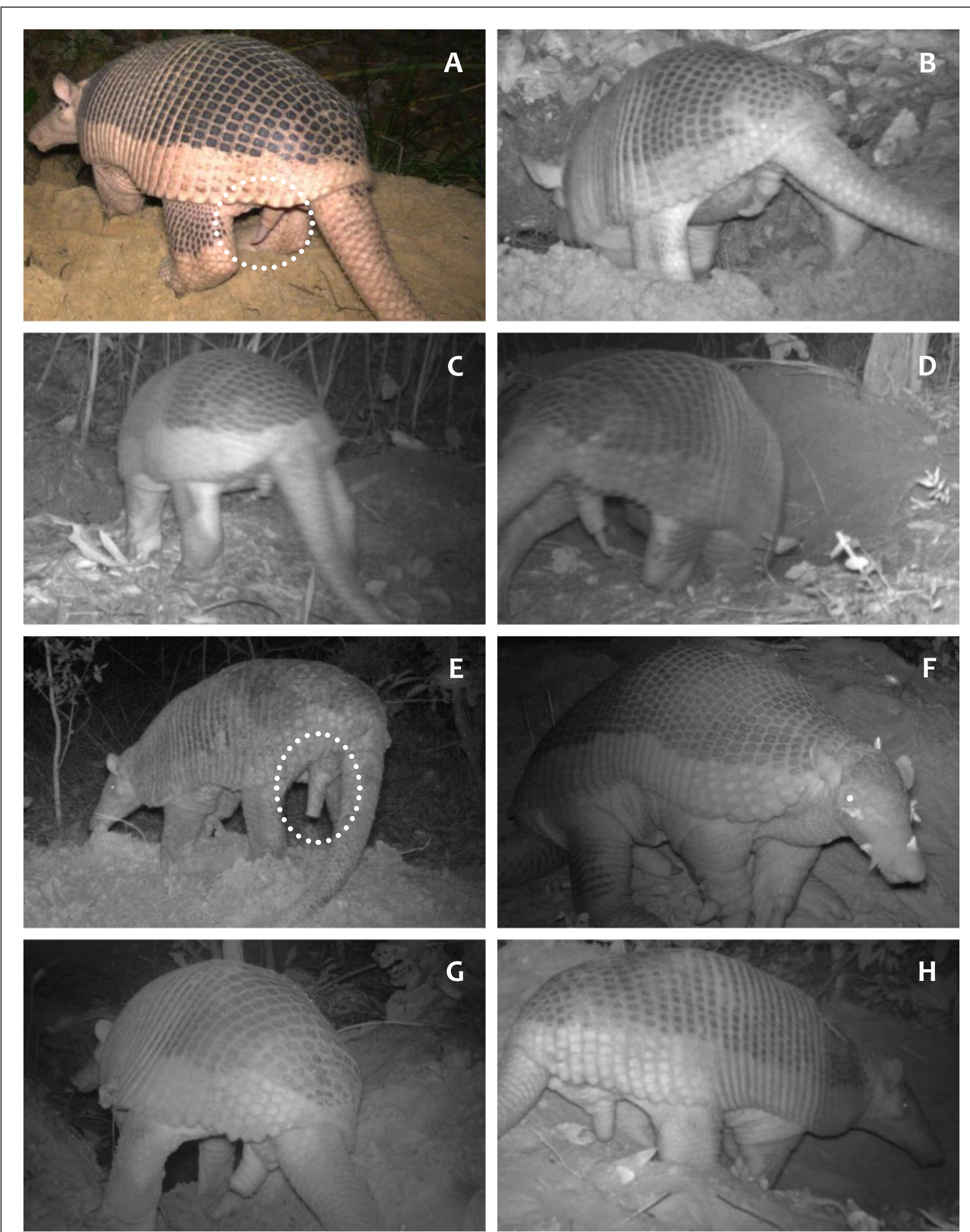

FIGURE 11. Sex identification and age class in male giant armadillos (P. maximus) (A) Region to be evaluated for identification patterns. (B-D) The male reproductive organ in a young animal. (E) Region to be evaluated for identification patterns. (F-H) The size of adult reproductive male organ. Age class and reproductive status can be inferred. 


\title{
SHORT COMMUNICATION
}

\section{Noteworthy records of the northern naked-tailed armadillo, Cabassous centralis (Cingulata: Chlamyphoridae), in Guatemala, Central America}

\author{
José Manuel Pellecer ${ }^{\text {A,1 Julio Rafael } \text { Morales }^{\mathrm{A}} \text { \& Sergio Guillermo Pérez }}{ }^{\mathrm{A}}$ \\ A Escuela de Biología, Universidad de San Carlos de Guatemala, Edificio T-10, Segundo Nivel, Ciudad Universitaria, zona 12, 01012, \\ Ciudad de Guatemala, Guatemala, Central America \\ E-mail: chepe2297@gmail.com (JMP), juliorafaelmorales@gmail.com (JRM), sergiogperezc@gmail.com (SGP) \\ ${ }^{1}$ Corresponding author
}

\begin{abstract}
The northern naked-tailed armadillo, Cabassous centralis (Miller, 1899), has a fragmented distribution that extends from Chiapas, Mexico, to Ecuador. Throughout its range, it is rare to see or capture individuals. Cabassous centralis is reported in only one previous paper for Guatemala; we provide here additional records for the presence of this armadillo in the northern tropical portion of Guatemala. In northern Guatemala C. centralis may be a little more common than originally thought. Nonetheless, we discuss the need to promote studies of its population and natural history to provide more information for determining its conservation status.
\end{abstract}

Keywords: geographic distribution, Laguna Lachuá, museum specimens, Petén, Quiché, Sierra Caral

Registros notables del armadillo de cola desnuda del norte, Cabassous centralis (Cingulata: Chlamyphoridae), en Guatemala, Centroamérica

Resumen El armadillo de cola desnuda, Cabassous centralis (Miller, 1899), tiene una distribución fragmentada desde Chiapas, México, hasta Ecuador. A lo largo de su rango es raro verlo o capturarlo. Cabassous centralis se reporta en un solo documento anterior para Guatemala; aquí proporcionamos registros adicionales de la presencia de este armadillo en la porción tropical del norte de Guatemala. En el norte de Guatemala C. centralis puede ser más común de lo que se pensaba originalmente. No obstante, discutimos la necesidad de promover estudios de su población e historia natural, para proporcionar más información sobre su estado de conservación.

Palabras clave: distribución geográfica, especímenes de museo, Laguna Lachuá, Petén, Quiché, Sierra Caral

Extant armadillos were traditionally considered a natural group contained within the family Dasypodidae (Gardner, 2005), but recent molecular studies (Delsuc et al., 2016) support splitting the group into two different families: Dasypodidae, which includes only the genus Dasypus Linnaeus, 1758, and Chlamyphoridae, which includes all other genera of extant armadillos, including naked-tailed armadillos in the genus Cabassous, as well as extinct armadillos of the subfamily Glyptodontinae (Delsuc et al., 2016). There are four currently recognized species of Cabassous, which probably shared a common ancestor during the early Miocene, and diverged from one another during the late Miocene to the Pleistocene (Delsuc et al., 2016).

Two species of armadillos are known to occur in Guatemala (McCarthy \& Pérez, 2006), the nine-banded armadillo, Dasypus novemcinctus, and the northern naked-tailed armadillo, Cabassous centralis. Dasypus novemcinctus is common and is found and hunted in many areas of the country, whereas C.centralis is apparently rare. The northern 
naked-tailed armadillo is a medium-sized mammal with a distribution that extends from southeast Mexico through Central America, to Colombia, eastern Venezuela, and northern Ecuador (Hayssen et al., 2013; Tirira et al., 2014). Cabassous centralis can be distinguished from $D$. novemcinctus by its smaller size, long and squared carapace shields, 10 to 13 movable bands in the middle of the carapace, wide head, rounded ears, naked tail (from which the common name is derived), and five claws on each foot, the central claw being much longer than the others. In contrast, $D$. novemcinctus has nine movable bands, slender ears, the tail is covered in scutes, and the general body form is narrower on the lateral sides (Reid, 2009).

Cabassous centralis is usually nocturnal and one of the most fossorial armadillos (Hayssen et al., 2013). Its habits are probably similar to those of the southern naked-tailed armadillo (C. unicinc$t u s)$, which is solitary and spends the majority of its time underground and digging long tunnels (Desbiez et al., 2018). The latter is probably the reason why both species are rarely seen. The International
Union for the Conservation of Nature has classified C. centralis in the category of "Data Deficient" (Tirira et al., 2014), due to the limited knowledge of wild populations.

Handley (1950) mentioned that, while there were no verified records for C. centralis in Guatemala, it might be possible to find it in places like the mountains of the Department of Quiché, as well as along the Pacific slope of the country. However, at that time there were no specimens associated with any locality. The species was not confirmed to be present in the country until 1989 (Cuarón et al., 1989), when two specimens were collected near the village of Mariscos, in the Department of Izabal, which is located in the tropical Caribbean portion of Guatemala. Besides records from the two collected specimens, Cuarón et al. (1989) also included one record based on field observations (western shore of Río Dulce, Izabal), and several verbal records (also from Izabal, and Tikal National Park, Department of Petén). Specimens from Izabal were associated with natural rubber, banana, cocoa, and

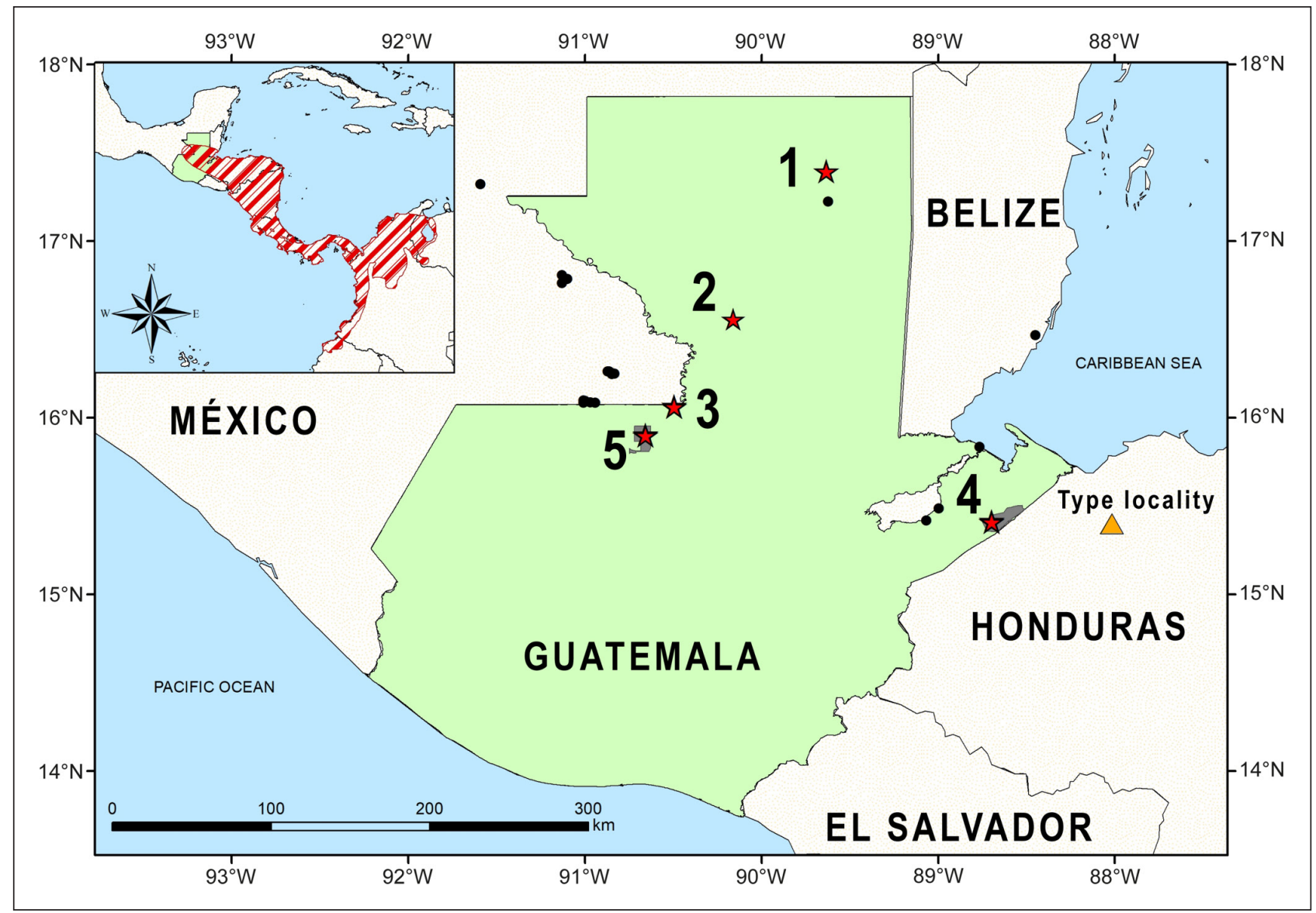

FIGURE 1. Map of Guatemala and adjacent countries showing old (small black circles) and new records (numbered stars) for the naked-tail armadillo, Cabassous centralis. 1. Uaxactún, Petén, 2. Sayaxche, Petén; 3. Quiché; 4. Sierra de Caral, Izabal; 5. Laguna Lachuá, Alta Verapaz. The triangle in Honduras represents the type locality at Chamelecón, Cortés, Honduras. Old records were taken from: Miller (1899), McCarthy (1982), Cuarón et al. (1989), González-Zamora et al. (2011), Figueroa-deLeón et al. (2016), Juárez-López et al. (2017). 


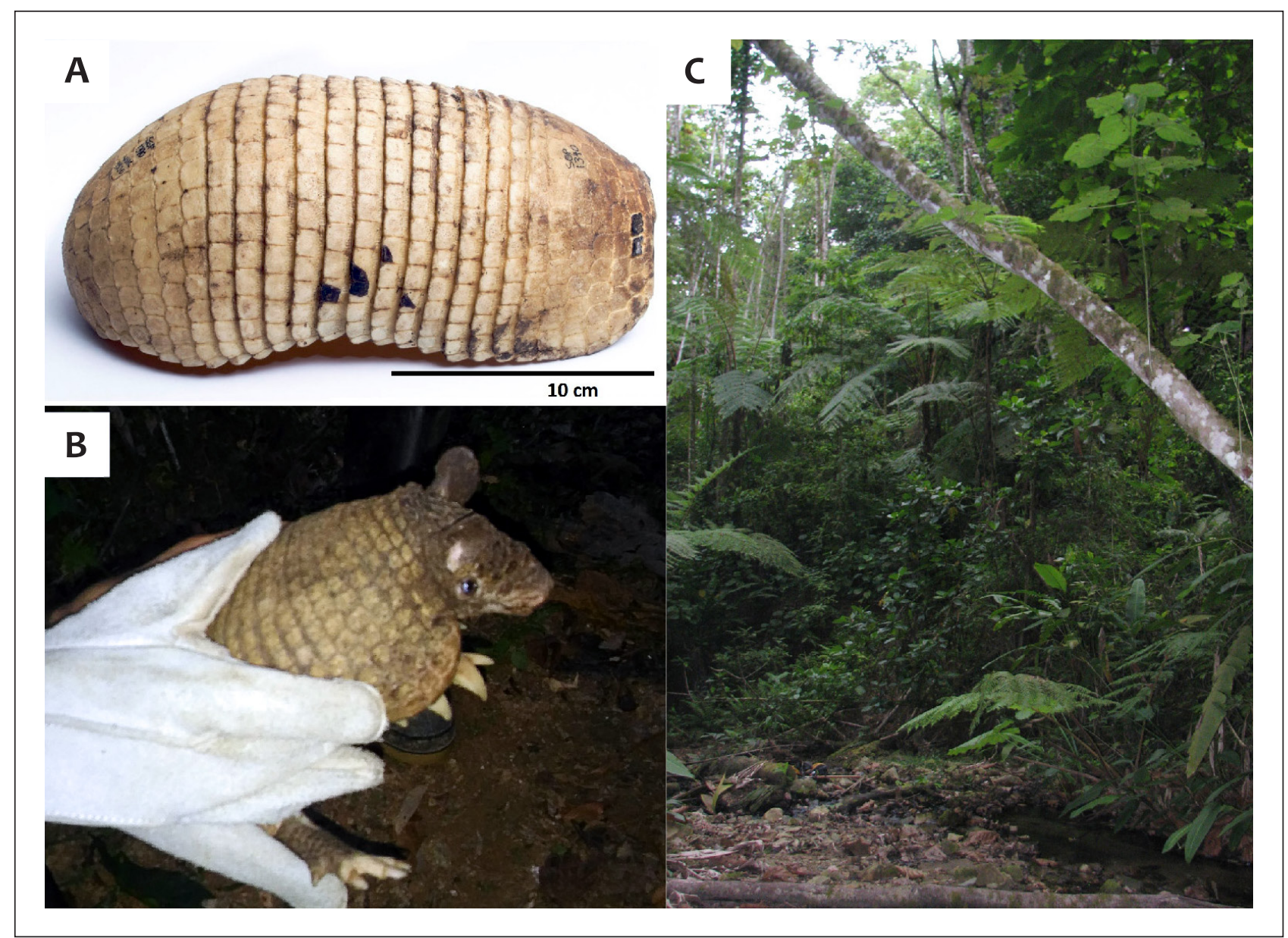

FIGURE 2. Carapace of specimen collected at Ixcán, Quiché (A), the specimen captured at Sierra Caral, Izabal (B) and the habitat of Cabassous centralis at Sierra Caral, Izabal (C).

corn plantations that also contained some areas of pristine tropical forest.

The objective of this note is to provide additional data on the presence of $C$. centralis in Guatemala that, together with records from Chiapas, Mexico, represent the northernmost limit of the distribution of this species, and of the Cabassous genus.

Since the 1990s, as part of various explorations and field work conducted by biologists of the Universidad de San Carlos de Guatemala, we have observed, captured or documented the presence of C. centralis in Guatemala. During our work we have followed suggested methods for the treatment of wild animals in the field (Sikes et al., 2011).

In March 1992, during field work near the community of Uaxactún, Department of Petén, Guatemala $\left(17^{\circ} 24^{\prime} \mathrm{N}, 89^{\circ} 38^{\prime} \mathrm{W}, 170 \mathrm{~m}\right.$ asl; FIG. 1, LOCALITY NUMBER 1), one of us (JRM) recorded the presence of C. centralis, based on field information from hunters. Uaxactún is entirely surrounded by pristine tropical forest, in the middle of the Mayan Biosphere Reserve, and is located approximately $25 \mathrm{~km}$ north of Tikal National Park. The vegetation at Uaxactún includes Brosimum alicastrum Sw., Calophyllum brasi- liense Cambess, Cedrela odorata L., Manilkara zapota (L.) P. Royen, Swietenia macrophylla King, Chamaedorea elegans Mart., and Chamaedorea oblongata Mart. (Morales, 1993; Rhader, 2014), among others. Later, in March 1994, JRM also found a decomposed dead specimen of $C$. centralis on a dirt road outside the town of Sayaxche, Petén, $\left(16^{\circ} 30^{\prime} \mathrm{N}, 90^{\circ} 10^{\prime} \mathrm{W}, 140 \mathrm{~m}\right.$ asl; FIG. 1, LOCALITY NUMBER 2), but he did not collect it.

Years later, on 16 June 2007, the carapace of an adult specimen of $C$. centralis, sex undetermined, was purchased by one of us (SGP field number 1370, catalogue number USAC 4530; FIG. 2A) while collecting small mammals around the community of Aldea Nueva Providencia, $8.5 \mathrm{~km} \mathrm{~N}$ and $31 \mathrm{~km} \mathrm{E}$ of Playa Grande, municipality of Ixcán, Department of Quiché, ca. $16^{\circ} 04^{\prime} \mathrm{N}, 90^{\circ} 30^{\prime} \mathrm{W}, 170 \mathrm{~m}$ asl (FIG. 1, LOCALITY NUMBER 3). The local farmers claimed to have recently hunted the animal for food, and only the "armor" remained to be sold to us. The measurements of the specimen's carapace, taken with a common desk rule, were $245 \mathrm{~mm}$ long from the base of the right front edge of the carapace to the base of the right rear edge, and $116 \mathrm{~mm}$ wide in the center of the carapace from the base of the left edge to the base of the right edge. 
Aldea Nueva Providencia is located in a flat area just $1.2 \mathrm{~km}$ south of the Guatemala-Mexico border, and $2.2 \mathrm{~km}$ south of the Trinitaria-Palenque highway on the Mexican side, in Chiapas. The area was originally dominated by tropical rain forest, some of which still remains inside the large wildlife protected areas on both sides of the border (Chajul and Lacandón on the Mexican side, and Laguna Lachuá on the Guatemalan side). The remaining area is now mainly covered by farm plantations and young regenerated forests ("guamiles"), with African Palm plantations increasing in size every year; some areas close to the Chixoy River are frequently flooded during the rainy season.

In September 2017, we conducted a field expedition to Reserva de Anfibios Sierra Caral, municipality of Morales, in the Department of Izabal, as part of a short training course for students in biology of field methods for the study of vertebrates. The reserve borders Honduras on the east side. Toward the end of the afternoon on 20 September, one of us (JP) captured a live adult $C$. centralis on a trail near the house of the park administration, $7 \mathrm{~km} \mathrm{~S}$ and $15 \mathrm{~km}$ E of Morales, Izabal, $15^{\circ} 24^{\prime} 34^{\prime \prime N}, 88^{\circ} 41^{\prime} 54^{\prime \prime} \mathrm{W}$, $531 \mathrm{~m}$ asl (FIG. 1, LOCALITY NUMBER 4). The specimen was captured manually, by grabbing the sides of the shell, photographed with a common cell phone, and then later released in the same place (FIG. 2B). The vegetation at Sierra de Caral is similar to the other tropical sites where Cabassous has been found previously in Izabal (FIG. 2C).

One additional record on the presence of C. centralis in Guatemala was later obtained when interviewing hunters in the community of Santa Lucía Lachuá, $52 \mathrm{~km} \mathrm{~N}, 27 \mathrm{~km} \mathrm{~W}$ of Cobán, Alta Verapáz, 1556'50"N, 90³7'36"W, 169 m asl (FIG. 1, LOCALITY NUMBER 5). The Mayan q'eqchi' people in Santa Lucía Lachuá refer to C. centralis as "kamenaq ib'oy", "kamenaq" meaning dead, and "ib'oy" meaning armadillo. The local Spanish name for this animal is "weche zorro" (fox armadillo). Some farmers consider it poisonous, or a scavenger animal that is said to consume human remains in the local cemetery. These traditional ideas are not widespread, however, because C. centralis is hunted for food in other communities. Representative vegetation at Santa Lucía Lachuá includes: C. odorata, Ceiba pentandra (L.) Gaertn., Dialium guianense (Aubl.) Sandwith, Genipa americana L., Psychotria poeppigiana Müll. Arg., Spondias mombin L., S. macrophylla, and Vochysia hondurensis Donn. Sm. (Ávila, 2004).

Cabassous centralis is considered rare in Guatemala, and in other parts of Central America such as Costa Rica (Sáenz-Bolaños \& Carrillo, 2009). However, our findings indicate that, although it is not as common as the nine-banded armadillo, the absence of records may be mainly due to the lack of specific studies about the species. The data presented here confirm the presence of $C$. centralis in the Atlantic tropical portion of Guatemala; however, its presence along the Pacific slope of the country remains uncertain. Because little information is available on the natural history of $C$. centralis, especially near the northernmost limit of its distribution, we consider the IUCN classification of this species as "Data Deficient" correct for Guatemala.

\section{ACKNOWLEDGEMENTS}

We appreciate the support of Consejo Nacional de Áreas Protegidas, in Guatemala City, for providing research and field permits to work in different parts of Guatemala, as well as Fundación para el Ecodesarrollo y la Conservación (FUNDAECO), Instituto Nacional de Bosques (INAB), Instituto de Antropología e Historia (IDAEH), and Escuela de Biología, Universidad de San Carlos. We thank César E. Fuentes for the georeferencing and mapping work; J. Renato Morales assisted with the pictures of the Cabassous carapace from the USAC collection; Ángel Xo, Rigoberto Bac and Ramiro Tox provided information and assistance at Lachuá National Park, and Carlos R. Vasquez provided the picture of habitat at Sierra Caral. We want to thank and dedicate this paper to the park rangers who are in the front line for the conservation of wildlife and protected areas in Guatemala.

\section{REFERENCES}

Ávila, R. 2004. Estudio base para el programa de monitoreo de la vegetación en la Zona de Influencia del Parque Nacional Laguna de Lachuá. Undergraduate thesis, Universidad de San Carlos de Guatemala, Guatemala. 75 pp.

Cuarón, A.D., I.J. March \& P.M. Rockstroh. 1989. A second armadillo (Cabassous centralis) for the faunas of Guatemala and Mexico. Journal of Mammalogy 70: 870-871. https://doi.org/10.2307/1381731

Delsuc, F., G.C. Gibb, M. Kuch, G. Billet, L. Hautier, J. Southon, J. Rouillard, J.C. Fernicola, S.F. Vizcaíno, R.E. MacPhee \& H.N. Poinar. 2016. The phylogenetic affinities of the extinct glyptodonts. Current Biology 26: R155-R156. https://doi.org/10.1016/j. cub.2016.01.039

Desbiez, A.L.J., G.F. Massocato, D. Kluyber \& R.C. Fernandes. 2018. Unraveling the cryptic life of the southern naked-tailed armadillo, Cabassous unicinctus squamicaudis (Lund, 1845), in a Neotropical wetland: home range, activity pattern, burrow use and reproductive behavior. Mammalian Biology 91: 95103. https://doi.org/10.1016/j.mambio.2018.02.006

Figueroa-de-León, A., E.J. Naranjo \& A. Santos-Moreno. 2016. Registros de Cabassous centralis (Cingulata: Dasypodidae) en la Reserva de la Biosfera Montes Azules y sitios aledaños, Chiapas, México. Edentata 17: 46-50. https://doi.org/10.2305/IUCN.CH.2016. EDENTATA-17-1.8.en 
Gardner, A.L. 2005. Order Cingulata. Pp. 94-99 in: Mammal species of the world (D.E. Wilson \& D. M. Reeder, eds.), third edition. The John Hopkins University Press, Baltimore.

González-Zamora, A., V. Arroyo-Rodríguez, A.M. GonzálezDi Pierro, R. Lombera, E. de la Peña-Cuéllar, J.L. Peña-Mondragón, O. Hernández-Ordoñez, C. Muench, A. Garmendia \& K.E. Stoner. 2011. The northern naked-tailed armadillo in the Lacandona rainforest, Mexico: new records and potential threats. Revista Mexicana de Biodiversidad 82: 581-586.

Handley, C. O. Jr. 1950. Game mammals of Guatemala. Pp. 141-162 in: A fish and wildlife survey of Guatemala (G.B. Saunders, A.D. Halloway \& C.O. Handley Jr., eds.). U.S. Fish and Wildlife Service Special Scientific Report 5: 1-162.

Hayssen, V., J. Ortega, A. Morales-Leyva \& N. Martínez-Mendez. 2013. Cabassous centralis (Cingulata: Dasypodidae). Mammalian Species 45: 12-17. https:// doi.org/10.1644/898.1

Juárez-López, R., M. Pérez-López, Y. Bravata-de la Cruz, A. Jesús-de la Cruz, F. M. Contreras-Moreno, D. Thornton \& M.G. Hidalgo-Mihart. 2017. Range extension of the northern naked-tailed armadillo (Cabassous centralis) in southern Mexico. Western North American Naturalist 77: 398-403. https://doi. org/10.3398/064.077.0311

McCarthy, T.J. \& S.G. Pérez. 2006. Land and freshwater mammals of Guatemala: faunal documentation and diversity. Pp. 625-674 in: Biodiversidad de Guatemala, Volumen I (E.B. Cano, ed.). Universidad del Valle de Guatemala, Guatemala.
McCarthy, T.J. 1982. Chironectes, Cyclopes, Cabassous and probably Cebus in southern Belize. Mammalia 46: 397-400.

Miller, G.S. 1899. Notes on the naked-tailed armadillos. Proceedings of the Biological Society of Washington 13: $1-8$.

Morales, J. 1993. Caracterización etnozoológica de la actividad de cacería en la comunidad de Uaxactún, Flores, Petén. Bachelor's thesis, Universidad de San Carlos de Guatemala, Guatemala. 114 pp.

Reid, F. 2009. A field guide to the mammals of Central America and southeast Mexico. Oxford University Press, New York. 346 pp.

Rhader, M. 2014. Caring for Xate, caring for Xateros. NGO monitoring, livelihoods, and plant-human relations in Uaxacún, Guatemala. Journal of Political Ecology 21: 372-388. http://dx.doi.org/10.2458/v21i1.21141

Sáenz-Bolaños, C. \& E. Carrillo. 2009. Registros de Cabassous centralis (Cingulata: Dasypodidae) en la Reserva Forestal Pacuare y Reserva Indígena Nairi Awari, Siquirres, Costa Rica. Brenesia 71-72: 69-70.

Sikes, R. S., W. L. Gannon, and the Animal Care and Use Committee of the American Society of Mammalogists. 2011. Guidelines of the American Society of Mammalogists for the use of wild mammals in research. Journal of Mammalogy 92: 235-253. https:// doi.org/10.1644/10-MAMM-F-355.1

Tirira, D. G., J. Diaz-N., M. Superina \& A.M. Abba. 2014. Cabassous centralis. The IUCN Red List of Threatened Species 2014: e.T3412A47437304. http://dx.doi. org/10.2305/IUCN.UK.2014-1.RLTS.T3412A47437304. en. Downloaded on 16 November 2018.

Received: 27 November 2018; Accepted: 13 March 2019 


\title{
COMUNICACIÓN BREVE
}

\section{Nuevos registros en Huánuco (Perú) y distribución potencial del armadillo peludo (Dasypus pilosus)}

\author{
E. Daniel $\operatorname{Cossios}^{\mathrm{A}, 1}$ \& Pedro Huanca-Foroca ${ }^{\mathrm{B}}$ \\ A Biosfera Consultores Ambientales, Calle Las Fresas 730, Miraflores, Lima, Perú \\ E-mail: dcossios@yahoo.com

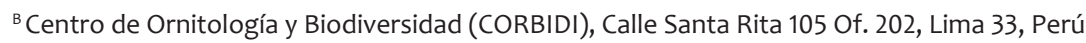 \\ ${ }^{1}$ Corresponding author
}

\begin{abstract}
Resumen Se obtuvieron tres fotografías del armadillo peludo (Dasypus pilosus) en el distrito de Chinchao, departamento de Huánuco, Perú. Estos son los primeros registros publicados para esta especie tomados con cámaras trampa y verifican su presencia en Chinchao luego de 36 años. Con estos nuevos datos la aplicación web Armadillo Mapper mostró los departamentos de Huancavelica, Ayacucho y Puno como nuevas zonas potenciales para la presencia de la especie. Nuestros resultados sugieren que la distribución del armadillo peludo debe seguir siendo estudiada en el sur del Perú y muestran la utilidad que pueden tener las cámaras trampa para ello.
\end{abstract}

Palabras clave: Armadillo Mapper, cámara trampa, Chinchao

New records in Huánuco (Peru) and potential distribution of the hairy long-nosed armadillo (Dasypus pilosus)

Abstract Three photographs of the hairy long-nosed armadillo (Dasypus pilosus) were obtained in the district of Chinchao, department of Huánuco, Peru. These are the first records for this species taken with camera traps, which confirm its presence in Chinchao after 35 years. With these new data, the Armadillo Mapper web application showed the departments of Huancavelica, Ayacucho and Puno as potential new areas for the presence of the species. Our results suggest that the distribution of the hairy long-nosed armadillo should continue to be studied in southern Peru and show how useful camera traps can be for this purpose.

Keywords: Armadillo Mapper, camera traps, Chinchao

El armadillo peludo, Dasypus pilosus, es uno de los armadillos menos conocidos y estudiados, no existiendo hasta el momento estudios sobre la biología, ecología o estado de conservación de este animal (Wetzel et al., 2008; Superina et al., 2014). Es considerado una especie con datos insuficientes (categoría DD) por la UICN (Superina \& Abba, 2014), aunque en el Perú, de donde es endémico, se lo considera en la categoría Vulnerable (VU, Decreto Supremo 004-2014-MINAGRI; MINAGRI, 2014).

A pesar de que la distribución del armadillo peludo es uno de los temas más estudiados sobre esta especie, existen pocos datos sobre la misma. Recientemente, Feng et al. (2017b) estimaron la distribución potencial del armadillo peludo a partir de especímenes de museo, ampliando así el entendimiento de las condiciones ambientales favorables para esta especie. Su trabajo derivó en la creación de la aplicación web Armadillo Mapper (AM), que permite actualizar el mapa de distribución potencial y conocer el nicho climático del armadillo peludo en base a tres variables: BIO6, temperatura mínima del mes más frío; BIO15, estacionalidad de la precipitación; y BIO16, precipitación del trimestre más lluvioso (Feng et al., 2017a).

Con el objetivo de estudiar la comunidad de mamíferos del distrito rural de Chinchao, en el departamento de Huánuco, Perú, se colocaron siete 
cámaras trampa (Bushnell Trophy Cam, USA), siendo la intención principal de ese estudio determinar la distribución y la actividad horaria del majás de montaña (Cuniculus tackzanowskii), un roedor de importancia cinegética en la zona. Las cámaras fueron colocadas en noviembre de 2016 a 20-40 $\mathrm{cm}$ del suelo, dentro del bosque, orientadas hacia el cruce de dos caminos de animales, y se las programó para que tomaran tres fotos por evento, con un periodo de pausa de cinco minutos entre cada evento y registrando la fecha y hora en cada fotografía. El 3 de diciembre de 2016, al cabo de 32 días (224 días-cámara) con las cámaras puestas en bosques intervenidos y cercanos a poblaciones humanas, se obtuvo una fotografía de armadillo peludo (FIG. 1). En los siguientes tres meses se consiguieron dos fotografías más, a razón de una fotografía por cada 287 días-cámara. La hora en la que fueron tomadas las tres fotografías varió entre las 22:15 y las 00:03 hs y la temperatura entre $\operatorname{los} 3{ }^{\circ} \mathrm{C}$ y $\operatorname{los} 5{ }^{\circ} \mathrm{C}$, siendo estos los primeros registros de armadillo peludo tomados con cámaras trampa. Con ellos se ha vuelto a reportar esta especie en el distrito de Chinchao luego de 36 años, teniendo en cuenta que el

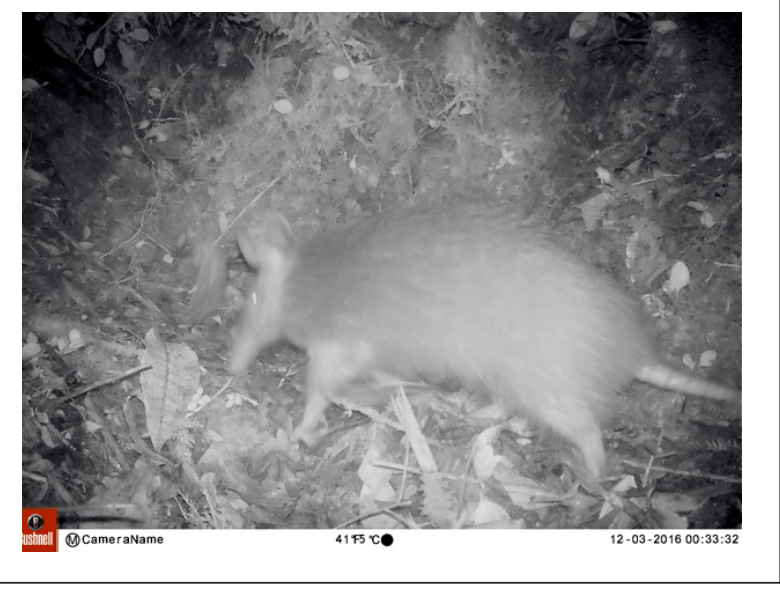

FIGURA 1. Fotografía de armadillo peludo, Dasypus pilosus, tomada con cámaras trampa en el distrito de Chinchao, Huánuco, Perú.

último registro en esa zona correspondía a un animal colectado en 1980 y depositado en el Museum of Southwestern Biology, de la Universidad de Nuevo México, con el código MSB:Mamm 49990.

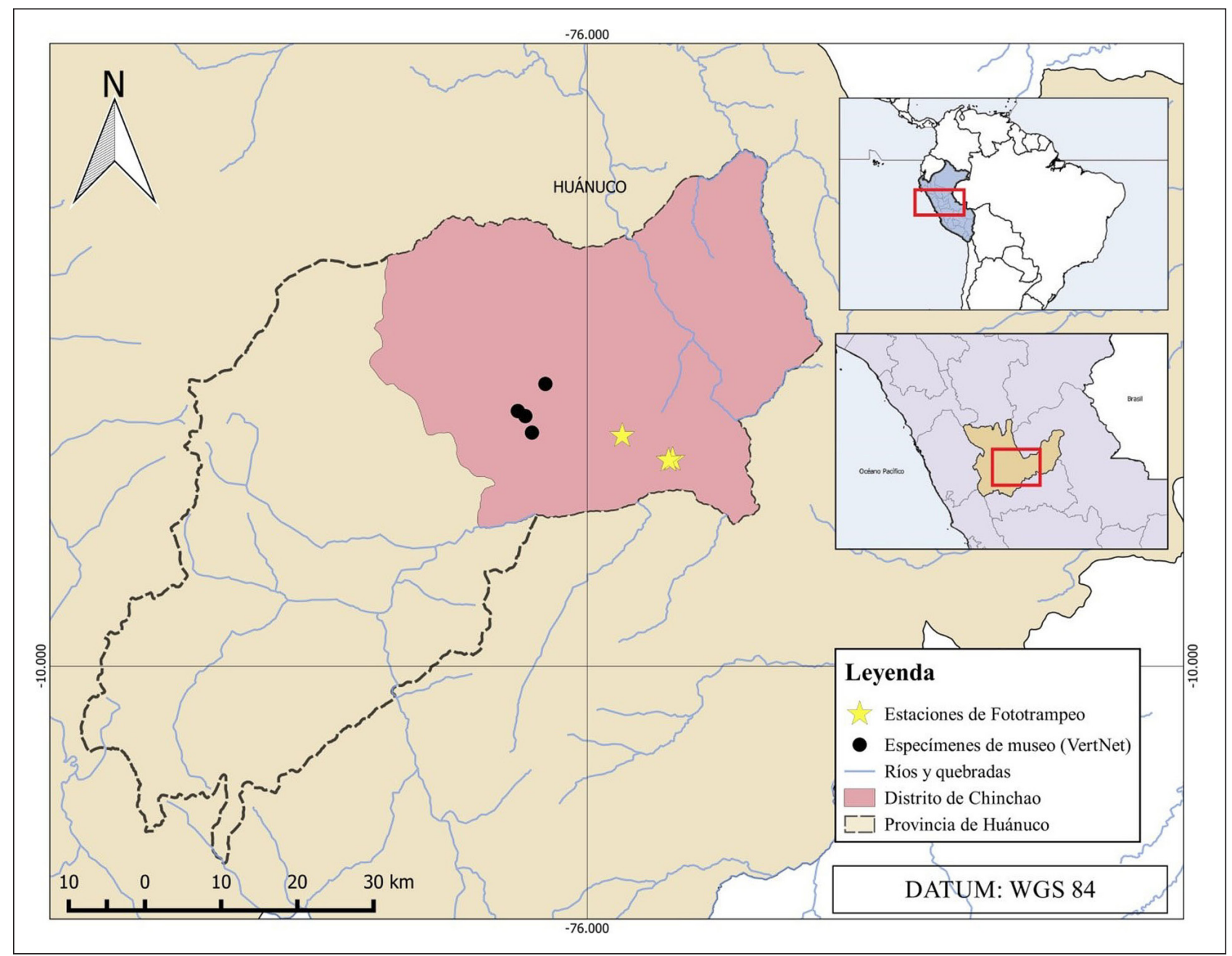

FIGURA 2. Ubicación de las cámaras trampa que registraron al armadillo peludo (estrellas). Se incluyen los registros de museo (con

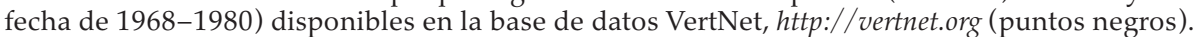




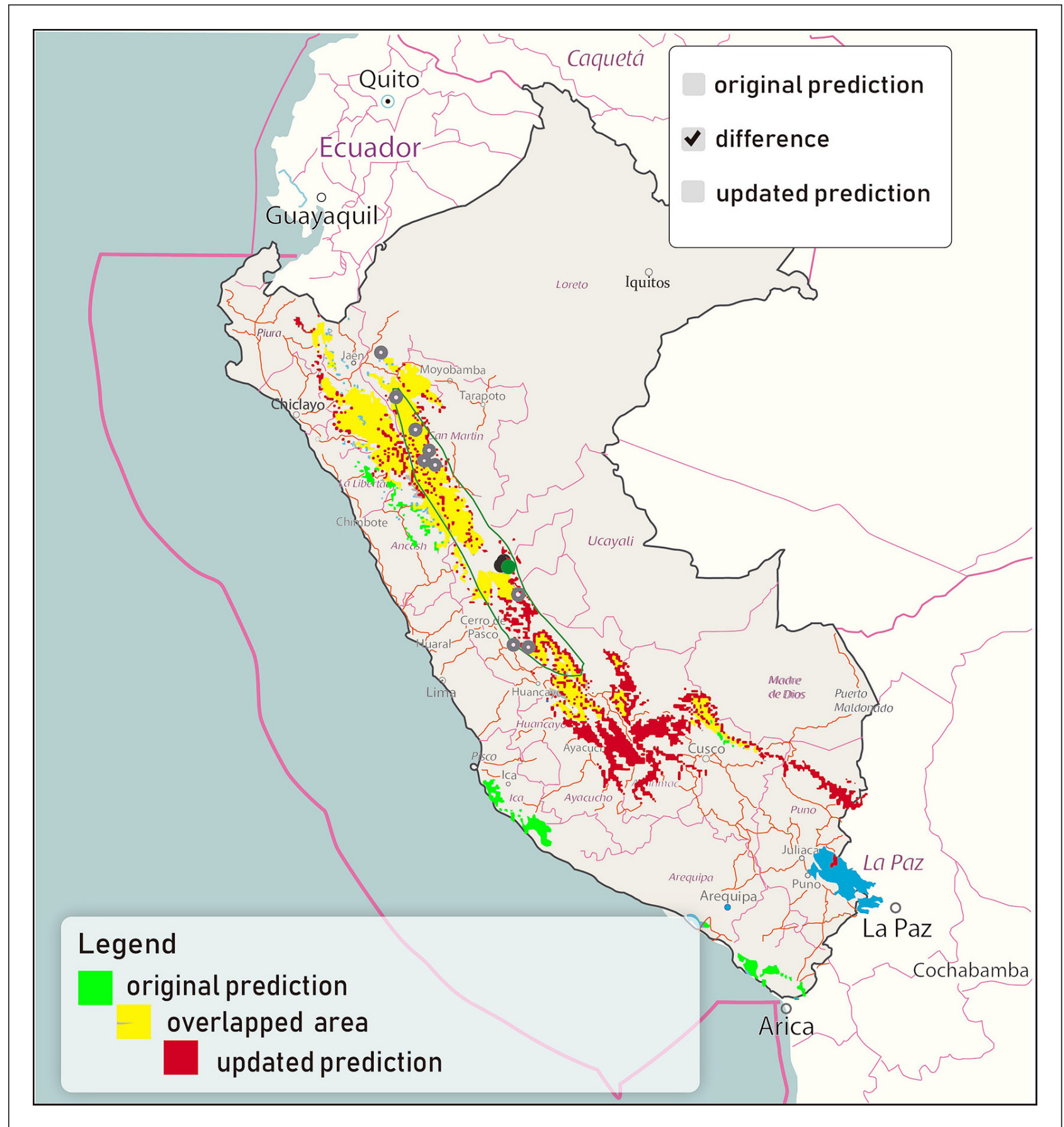

FIGURA 3. Mapa de distribución potencial inferida por Armadillo Mapper. Los puntos grises representan los registros usados por Feng et al. (2017b). El punto verde, al centro del mapa, corresponde a los registros de este estudio en el departamento de Huánuco. En amarillo se presenta la coincidencia entre la predicción anterior, hecha con los datos de Feng et al. (2017b), y el área inferida actualmente con los nuevos registros; en rojo el área perteneciente únicamente a la nueva predicción; y en verde el área perteneciente únicamente a la predicción anterior.

Las fotografías fueron tomadas en un área situada entre los 3.284 y los $3.391 \mathrm{msnm}$, en las loca-

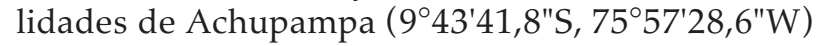
y Huanacaure $\left(9^{\circ} 45^{\prime} 22,9^{\prime \prime} S, 75^{\circ} 53^{\prime} 51,2^{\prime \prime} \mathrm{W}\right.$ y $9^{\circ} 45^{\prime}$ $\left.26,5^{\prime \prime} \mathrm{S}, 75^{\circ} 54^{\prime} 08,8^{\prime \prime} \mathrm{W}\right)$ en el distrito de Chinchao, provincia y departamento de Huánuco (FIG. 2). En Achupampa, la cámara fue colocada en un borde de bosque relicto en medio de una turbera de Sphagnum sp., en un ambiente con poca presencia humana. En Huanacaure, el ambiente fue un bosque montano dominado por árboles achaparrados, matorrales arbustivos y Chusquea sp., colindante con campos de cultivo, y que soporta actividades extractivas ocasionales de madera y de ganadería de bovinos. La presencia de perros domésticos en Huanacaure es común, pudiendo impactar negativamente en la fauna local. Los dos lugares de registro de Huanacaure estuvieron distanciados $0,6 \mathrm{~km}$ 
entre sí, mientras que el tercero, en Achupampa, se encuentra a más de $6 \mathrm{~km}$ de ellos.

La herramienta online AM creada por Feng et al. (2017a) fue utilizada para verificar si los puntos de registro causan un cambio en la distribución potencial inferida para el armadillo peludo. Para esto se introdujeron los tres nuevos registros, y debido a la cercanía entre los dos registros de Huanacaure y a que AM emplea cuadrículas de resolución de 2,5 arcmin, ambos registros deberían comportarse como uno solo.

En comparación con el mapa inferido por Feng et al. (2017b), la nueva distribución potencial inferida para el armadillo peludo se reduce ligeramente en su lado occidental, desapareciendo parte de la distribución inferida previamente en los Andes centrales y en la costa sur del Perú, y se amplía hacia el sur del país, principalmente en los departamentos de Huancavelica y Ayacucho, y en la región de yungas del norte del departamento de Puno (FIG. 3). Por otro lado, los nuevos registros obtenidos por fototrampeo se encuentran dentro del polígono definido por la temperatura media anual y la precipitación anual previamente inferido por Feng et al. (2017b).

Nuestros resultados sugieren que para tener una mejor idea de la distribución del armadillo peludo ésta debe seguir siendo estudiada, principalmente en el sur del Perú, y muestran la utilidad que pueden tener las cámaras trampa en ello, así como en la investigación de diversos aspectos de su ecología, como la actividad horaria y preferencias de hábitat.

\section{REFERENCIAS}

Feng, X., M.C. Castro, E. Linde \& M. Papes. 2017a. Armadillo Mapper: A case study of an online application to update estimates of species' potential distributions. Tropical Conservation Science 10: 1-5. https://doi.org/10.1177/1940082917724133

Feng, X., M.C. Castro, K. McBee \& M. Papes. 2017b. Hiding in a cool climatic niche in the Tropics? An assessment of the ecological biogeography of hairy long-nosed armadillos (Dasypus pilosus). Tropical Conservation Science 10: 1-13. https://doi. org/10.1177/1940082917697249

MINAGRI - Ministerio de Agricultura y Riego. 2014. Decreto Supremo No004-2014-MINAGRI, Decreto Supremo que aprueba la actualización de la lista de clasificación y categorización de las especies amenazadas de fauna silvestre legalmente protegidas. El Peruano 520497-520504.

Superina, M. \& A.M. Abba. 2014. Dasypus pilosus. The IUCN Red List of Threatened Species 2014: e. T6291A47441122. http://dx.doi.org/10.2305/IUCN. UK.2014-1.RLTS.T6291A47441122.en. Consultada $1^{\circ}$ de agosto de 2017.

Superina, M., N. Pagnutti \& A. M. Abba. 2014. What do we know about armadillos? An analysis of four centuries of knowledge about a group of South American mammals, with emphasis on their conservation. Mammal Review 44: 69-80. http://dx. doi.org/10.1111/mam.12010

Wetzel, R. M., A. L. Gardner, K.H. Redford \& J.F. Eisenberg. 2008. Order Cingulata. Pp: 128-157 in: Mammals of South America. Volume 1: marsupials, xenarthrans, shrews, and bats (A.L. Gardner, ed.). The University of Chicago Press, Chicago. https:// doi.org/10.7208/chicago/9780226282428.001.0001

Recibido: 29 de marzo de 2019; Aceptado: 5 de junio de 2019 


\title{
COMUNICACIÓN BREVE
}

\section{Nuevos casos de comportamiento agonístico entre machos adultos de Bradypus variegatus en el Caribe colombiano}

\author{
Jairo Andrés Díaz Arcia ${ }^{\mathrm{A}, 1}$ \& Julio J. Chacón Pacheco ${ }^{\mathrm{A}, \mathrm{B}}$ \\ A Universidad de Córdoba, Facultad de Ciencias Básicas, Carrera 6, No. 77-305, CEP 230002, Montería, Córdoba, Colombia \\ E-mail: jairodiazarcia@gmail.com (JDA) \\ ${ }^{B}$ Institución Educativa José María Córdoba, Calle 29, No. 16b-43, Barrio San José, CEP 230002, Montería, Córdoba, Colombia \\ E-mail: jchacon_bio@hotmail.com (JCP) \\ ${ }^{1}$ Autor para correspondencia
}

Resumen Esta investigación tuvo como objetivo describir las posibles causas de comportamiento agonístico entre machos adultos de Bradypus variegatus en un área de bosque seco tropical en el Caribe colombiano. Durante transectos en la Finca Calle Larga en el municipio de San Pedro de Urabá, departamento de Antioquia, Colombia, se observaron enfrentamientos entre machos en época de apareamiento. La fragmentación promovería la competencia entre machos por recursos limitados en época seca, donde hay poca cobertura foliar. Estos hallazgos aportan información sobre los efectos que genera la deforestación al concentrar un alto número de individuos en los pocos fragmentos de bosque.

Palabras clave: competencia, fragmentación, perezoso de tres dedos, recursos, reproducción

New cases of agonistic behavior among adult Bradypus variegatus in the Colombian Caribbean

Abstract The objective of this research was to identify possible causes of agonistic behavior among adult Bradypus variegatus males in an area of tropical dry forest on Calle Larga Farm, San Pedro de Urabá, Antioquia, Colombia. Agonistic behavior between males was observed during mating season. While these interactions could reflect competition for mates, habitat fragmentation may further promote agonism because (a) sloths are highly concentrated into a few forest fragments, thereby increasing the potential for interactions, and (b) high densities may lead to increased competition for limited resources during dry season, when there is little foliage cover. Our findings provide additional information on the effects of deforestation on the behavior of sloths.

Keywords: competition, fragmentation, three-toed sloth, reproduction, resources

Los perezosos de tres dedos, Bradypus variegatus, se encuentran reportados en diferentes tipos de hábitat incluyendo bosques secos tropicales, bosques húmedos y bosques de tierras bajas. Son herbívoros folívoros, diurnos y nocturnos, generalmente pacíficos (MADS, 2016). Son exclusivamente arborícolas, descendiendo al suelo para defecar (Castro-Vásquez et al., 2010) y poder desplazarse por falta de cobertura arbórea.

Esta especie se caracteriza por su movilidad relativamente lenta en comparación con otros mamí- feros arbóreos de características similares (Sunquist \& Montgomery, 1973; Polanco-Ochoa, 1998; Urbani \& Bosque, 2007; Carrillo-Bilbao et al., 2016). Presenta comportamiento social principalmente durante el período de apareamiento y el cuidado parental de la madre a su cría (Eisenberg, 1981; Pinheiro, 2008; Pessoa et al., 2018). Sin embargo, también se han reportado entre dos y cuatro individuos compartiendo un mismo árbol durante actividades de alimentación y descanso (Sunquist \& Montgomery, 1973; Polanco-Ochoa, 1998; Lara-Ruiz \& SrbekAraujo, 2006). 
Al ser una especie poco sociable, el uso de señales permite mantener un tipo de comunicación al momento de la reproducción (Carranza, 1994; Lara-Ruiz \& Srbek-Araujo, 2006). En períodos de apareamiento las hembras realizan vocalizaciones, emitiendo un grito agudo durante intervalos regulares por varios días con el fin de atraer a los machos para la cópula (Gilmore et al., 1994; Polanco-Ochoa, 1998; Lara-Ruiz \& Srbek-Araujo, 2006; Dünner-Oliger \& Pastor-Nicolai, 2017). Cuando se dan encuentros entre machos, se puede presentar una conducta agonística (Greene, 1989; DünnerOliger \& Pastor-Nicolai, 2017).

El comportamiento agonístico es un modelo de interacción social asociado con el enfrentamiento, la retirada, huida, amenaza, defensa y apaciguamiento (Slater, 2000; Caballero, 2017). Esta técnica de competencia intraespecífica abarca todas las conductas asociadas con el conflicto (Fernández \& Ortega, 1990; Carranza, 1994). Los recursos limitados son unas de las principales causas de enfrentamiento en especies animales, especialmente entre machos adultos (Fernández \& Ortega, 1990). Este tipo de comportamiento se convierte en una herramienta en la lucha por la supervivencia o por la obtención de pareja (Caballero, 2017).

En los perezosos del género Bradypus, estos comportamientos se dan en hembras por competición de espacios y en machos principalmente por la defensa de hembras (Greene, 1989; Pessoa et al., 2018). Estas interacciones entre machos se han descrito como persecuciones de un individuo a otro entre la vegetación, donde se propician golpes y zarpazos, vocalizando, hasta que finalmente uno cede y abandona el lugar (Greene, 1989; DünnerOliger \& Pastor-Nicolai, 2017; Pessoa et al., 2018).

A pesar de los estudios realizados sobre el comportamiento de la especie en el norte de Colombia (Ballesteros et al., 2009; Castro-Vásquez et al., 2010; Acevedo-Quintero et al., 2011), no se han registrado aportes a este tipo de interacciones, por lo que este trabajo tuvo como objetivo describir nuevas evidencias y causas de comportamientos agonísticos entre machos adultos de Bradypus variegatus en un área de bosque seco tropical en el Caribe colombiano.

Desde junio de 2018 hasta marzo de 2019 se realizaron muestreos en la Finca Calle Larga, en zona rural del municipio de San Pedro de Urabá, departamento de Antioquia, Colombia ( $8^{\circ} 17^{\prime} 53,98^{\prime \prime N}$, $76^{\circ} 21^{\prime} 53,48^{\prime \prime} \mathrm{W} ; 200 \mathrm{msnm}$ ), como parte del proyecto «Efecto de la intervención antrópica en la abundancia, estructura poblacional y uso de hábitat de perezosos (Mammalia: Xenarthra) en el Caribe Colombiano».

Esta zona se caracteriza por presentar una temperatura promedio de $27^{\circ} \mathrm{C}$ a $30^{\circ} \mathrm{C}$ y precipitación anual de 1.500 a $2.000 \mathrm{~mm}$, ubicada dentro de la zona de vida bosque seco tropical. La finca está localizada en la vereda El Caño, margen derecha, a 15 minutos de la zona urbana, con una extensión de 33 ha. En ella se presenta una matriz agropecuaria, con un fragmento aislado de bosque ribereño de 3 ha, en donde circulan tres fuentes de agua: Río San Juan, Caño Rumbón y Quebrada El Medio.

La metodología consistió en el uso de transectos lineales de ancho variable, donde se realizaron observaciones de comportamiento con ayuda de binoculares Nikon $10 \times 50 \mathrm{~mm}$ en los periodos de la mañana (7:00-10:00 hs) y en la tarde (15:3018:00 hs). Como evidencias se tomaron registros fotográficos de los comportamientos observados.

El esfuerzo de muestreo fue de 144 horas. Fueron registrados 25 individuos (12 hembras y 13 machos) adultos de B. variegatus. Las observaciones permitieron registrar la presencia de machos compartiendo el mismo árbol con hembras en diferentes estratos, sin presentar ningún tipo de agresión, realizando actividades como descanso, desplazamiento, alimentación, tomando el sol y vigilancia, de acuerdo a las actividades comportamentales definidas por Castro-Vásquez et al. (2010).

Se evidenciaron dos casos de comportamiento agonístico.

El primer caso fue observado el 30 de diciembre de 2018 por uno de los autores (JDA). Se encontraron dos machos adultos (FIG. 1) en el suelo en horas de la mañana (10:18 hs), los cuales pudieron haber caído posiblemente durante el enfrentamiento para lograr aparearse con una hembra que se encontraba a unos $5 \mathrm{~m}$ de altura en un árbol de tachuelo (Zanthoxylum rhoifolium). Este último se encontraba aislado del parche de bosque ripario, conectado únicamente por una palmera de coco (Cocos nucife$r a)$, siendo el único paso para llegar hasta la hembra desde el fragmento circundante de la Quebrada El Medio. Se asume que los machos pudieron haber caído, debido a que no se evidenciaron en la zona, señales de arrastre en el suelo por parte de los perezosos para llegar hasta el árbol Z. rhoifolium.

Los individuos presentaban una posición de enrollamiento con sus extremidades posteriores, mientras que se agredían mutuamente con mordidas y las garras de sus extremidades anteriores (FIG. 1). Uno de los machos (A) presentaba un mayor tamaño, siendo esta característica ventajosa sobre el otro individuo (B). El individuo B, de menor tamaño, emitía vocalizaciones de corta duración frente al daño que estaba recibiendo. Esta acción se prolongó por unos $7 \mathrm{~min}$. Después de esto los machos lograron abrazarse completamente tratando de enterrar sus garras en el oponente. A pesar del daño que se ocasionaban mutuamente, no 


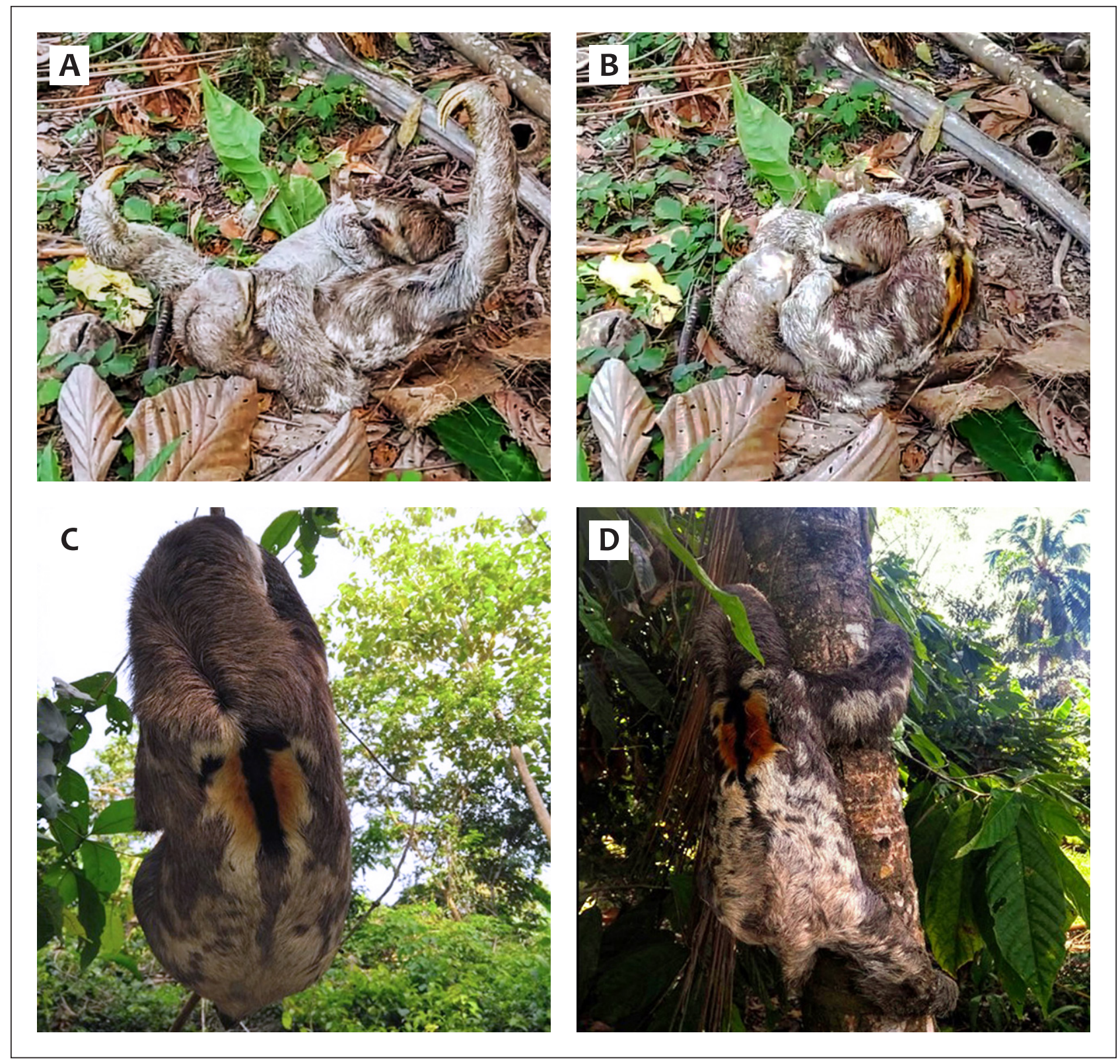

FIGURA 1. Comportamiento agonístico entre machos adultos de Bradypus variegatus encontrados en el suelo de la Finca Calle Larga en el municipio de San Pedro de Urabá, departamento de Antioquia, Colombia. A. Extremidades anteriores en posición de ataque. B. Enrollados completamente, mordiéndose y tratando de enterrar sus garras en el oponente. C-D. Características del espéculo de machos.

mostraban ninguna señal de huida, aferrándose aún más para conseguir agredir al otro (FIG.1).

Con el fin de proteger y resguardar los individuos, fueron separados después de evidenciar que el macho en desventaja (B) se encontraba en riesgo de muerte. Se observaron heridas en los dos individuos, causadas probablemente por sus garras filosas. También se evidenció que el espéculo de ambos individuos presentaba un olor característico parecido al pelaje de los ovinos. Para evitar un segundo enfrentamiento los perezosos fueron liberados por los investigadores a una distancia de aproximadamente $500 \mathrm{~m}$ entre ellos. El macho que se encontraba en peor estado (B) fue liberado lejos del lugar y el macho vencedor (A) cerca de la hembra.

El segundo caso fue reportado el 18 de marzo de 2019, en horas de la tarde (13:21 hs), en época seca, cuando la vegetación de esta zona, en su mayoría caducifolia, presentaba poca disponibilidad del recurso alimenticio para los perezosos. Fueron encontrados dos machos adultos de talla similar (FIG. 2) en un árbol de jobo (Spondias mombin), separados a unos pocos centímetros de distancia el uno del otro. Uno de los perezosos (C) se encontraba en la parte terminal de la rama mostrando una posición de huida, mientras que el otro individuo (D) se encontraba por debajo, estirando su extremidad 

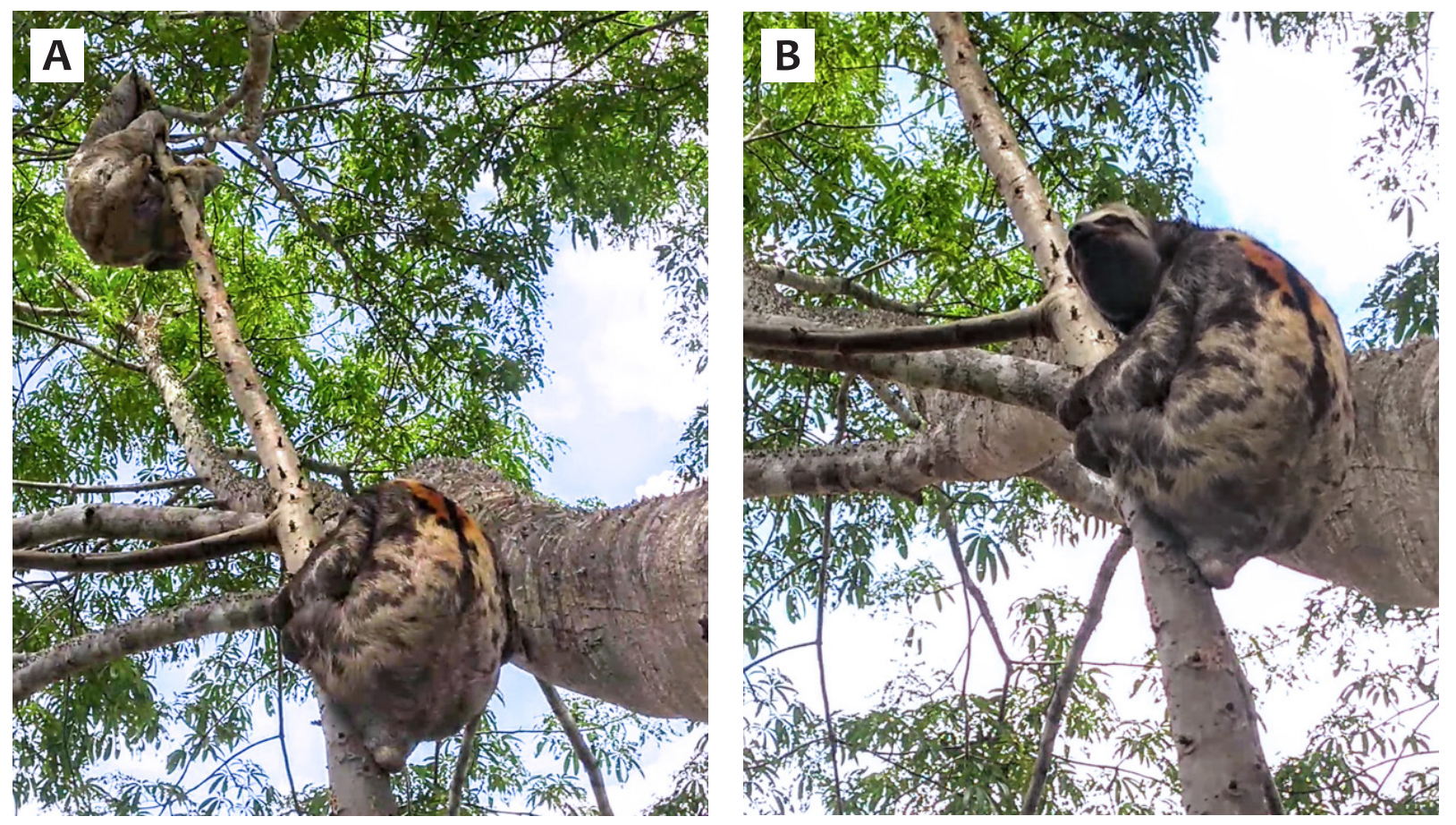

FIGURA 2. Comportamiento agonístico entre machos adultos de Bradypus variegatus en árbol de jobo (Spondias mombin) durante la época seca en la Finca Calle Larga en el municipio de San Pedro de Urabá, departamento de Antioquia, Colombia. A. Perezoso (C) en parte terminal de la rama mostrando una posición de huida. B. Perezoso (D) deteniendo el ataque al notar la presencia de observadores.

anterior derecha tratando de alcanzar y agredir con sus garras al otro perezoso (FIG. 2). La observación se prolongó por más de una hora. El perezoso D, al notar la presencia de observadores, tomó una posición de enrollamiento en la rama deteniendo el ataque, mientras que el individuo $\mathrm{C}$ mantuvo una posición de protección durante toda la agresión (FIG. 2).

Las observaciones de este estudio reportan nuevas evidencias de las causas probables del comportamiento agonístico entre los perezosos. El primer caso, como se ha observado en otros estudios, se dio durante el periodo de apareamiento, antes de la época lluviosa, producto muy posiblemente de la competencia por hembras entre machos adultos de B. variegatus en época reproductiva (Dünner-Oliger \& Pastor-Nicolai, 2017; Pessoa et al., 2018). Adicionalmente, este caso aporta información sobre el comportamiento agonístico de la especie al tratarse de un encuentro de dos individuos luchando enrollados, a diferencia de las persecuciones de un individuo a otro reportadas anteriormente (Greene, 1989; Dünner-Oliger \& Pastor-Nicolai, 2017; Pessoa et al., 2018). Además, al igual a lo descrito por Pinheiro \& Esbérard (2011), en este encuentro se registró una sustancia grasa, amarillenta y de olor desagradable segregada por el espéculo luego del enfrentamiento por apareamiento o territorio.

Otra causa de enfrentamiento agonístico es la lucha por territorio y fuentes de alimento. El Caribe colombiano actualmente es una de las principales áreas de distribución de $B$. variegatus en el país (Moreno \& Plese, 2006; Humanez-López et al., 2015) y donde los ecosistemas han sido más afectados por la fragmentación (Acevedo-Quintero et al., 2011). Durante la época seca del año (diciembre-abril), la mayoría de la vegetación arbórea disminuye en forma importante su follaje (Ballesteros et al., 2009), lo cual generaría una mayor competencia por alimento entre los perezosos. El municipio de San Pedro de Urabá y el área de estudio donde se realizó esta investigación presentan un alto grado de fragmentación debido a las actividades agropecuarias que se desarrollan, reduciendo el rango de distribución espacial y concentrando a los perezosos en el área de bosque ribereño cerca a los afluentes de agua. Así mismo, se reduce la oferta de alimento, como S. mombin, una especie importante en la dieta de los perezosos de acuerdo a las observaciones en campo y a lo reportado por Ballesteros et al. (2009).

Estos casos brindan nuevo conocimiento sobre la conducta de machos adultos de $B$. variegatus en ambientes naturales, influenciados por la necesidad de reproducirse en periodos de apareamiento y por las condiciones desfavorables del hábitat en época seca. Es así que los cambios en el paisaje producto de la fragmentación influirían en la conducta de los animales, pudiendo afectar las relaciones intraespecíficas (Laiolo \& Arroyo-Solís, 2011). 


\section{REFERENCIAS}

Acevedo-Quintero, J., D. Sánchez Granada \& T. Plese. 2011. Abundancia y preferencia de hábitat de Bradypus variegatus y Choloepus hoffmanni durante la época seca en dos fragmentos de bosque seco en Arboletes, Antioquia, Colombia. Edentata 12: 36-44. https://doi.org/10.5537/020.012.0106

Ballesteros, J., K. Reyes \& J. Racero-Casarrubia. 2009. Estructura poblacional y etología de Bradypus variegatus en fragmento de bosque seco tropical, Córdoba - Colombia. Revista MVZ Córdoba 14: 1812-1819. https://doi.org/10.21897/rmvz.341

Caballero, A. 2017. Caracterización del comportamiento agonístico en machos de Ctenomys pearsoni. Tesis de grado, Universidad de la República, Uruguay. 44 pp.

Carranza, J. 1994. Etología. Una introducción a la ciencia del comportamiento animal. Universidad de Extremadura, España. 590 pp.

Carrillo-Bilbao, G., V. Curicama, R. Ruíz \& S. MartinSolano 2016. Área de vida, dieta, preferencia de estrato vertical y uso del tiempo de Bradypus variegatus, liberados en la Estación Científica Agroecológica Fátima. Revista Bionatura 1: 118-122. https://doi.org/10.21931/RB/2016.01.03.4

Castro-Vásquez, L., M. Meza, T. Plese \& S. Moreno-Mora. 2010. Activity patterns, preference and use of floristic resources by Bradypus variegatus in a tropical dry forest fragment, Santa Catalina, Bolívar, Colombia. Edentata 11: 62-70. https://doi. org/10.1896/020.011.0111

Dünner-Oliger, C. \& G. Pastor-Nicolai. 2017. Manual de manejo, medicina y rehabilitación de perezosos. Fundación Huálamo, Chile. 154 pp.

Eisenberg, J. 1981. The mammalian radiations. An analysis of trends in evolution, adaptation, and behavior. University of Chicago Press, Chicago and London. 610 pp.

Fernández, C. \& J. Ortega. 1990. El comportamiento agonístico de hembras adultas de Lycosa tarentula fasciiventris (Araneae, Lycosidae). Journal of Arachnology 18: 49-58.

Gilmore, D. P., C. P. Da Costa, A. Cabral, D. P. F. Duarte, I. Montgomery \& C.A. Wilson. 1994. Further studies on reproductive function in the three-toed sloth, Bradypus tridactylus. Medical Science Research 22: 255-256.

Greene, H.W. 1989. Agonistic behavior by three-toed sloths, Bradypus variegatus. Biotropica 4: 369-372. https://doi.org/10.2307/2388289

Humanez-López, E., J. Chacón-Pacheco \& T. Plese. 2015. Áreas de extracción de Xenartros en el Caribe colombiano. Edentata 16: 65-68.

Laiolo, P. \& A. Arroyo-Solís. 2011. La fragmentación del hábitat como determinante de la diferenciación de los sistemas de comunicación animal. Revista Ecosistemas 20: 46-53.
Lara-Ruiz, P. \& A.C. Srbek-Araujo. 2006. Comportamento potencialmente reprodutivo da preguiça-comum, Bradypus variegatus (Xenarthra; Bradypodidae): Observações de campo. Edentata 7: 44-46. https://doi.org/10.1896/1413-4411.7.1.44

MADS - Ministerio de Ambiente y Desarrollo Sostenible. 2016. Programa nacional para la conservación y uso sostenible de las especies del superorden Xenarthra presentes en Colombia. Plan de acción 2014-2023. Ministerio de Ambiente y Desarrollo Sostenible y Fundación AIUNAU, Bogotá, Colombia. 54 pp.

Moreno, S. \& T. Plese. 2006. The illegal traffic in sloths and threats to their survival in Colombia. Edentata 7: 10-18. https://doi.org/10.1896/1413-4411.7.1.10

Pessoa, E., A. Zevêdo \& C. Soares. 2018. Agonistic interactions in the brown-throated three-toed sloth, Bradypus variegatus (Pilosa: Bradypodidae), in an urban environment in Rio Tinto, Paraíba, Brazil. Edentata 19: 42-46. https://doi.org/10.2305/IUCN. CH.2018.Edentata-19-1.5.en

Pinheiro, S. D. 2008. Comportamento alimentar da preguiça comum Bradypus variegatus (Schinz, 1825) (Xenarthra, Bradipodidae) no parque centenário de Barra Mansa, RJ. Dissertação de Mestrado, Universidade Federal de Juiz de Fora, Juiz de Fora, Brasil. $122 \mathrm{pp}$.

Pinheiro, S.D. \& E.L.C. Esbérard 2011. Relationship between agonistic behavior and physiological changes of the speculum in brown-throated sloth Bradypus variegatus Schinz, 1825 (Xenarthra: Bradypodidae). P. 140 in XX Jornadas Argentinas de Mastozoología (SAREM, ed.), La Plata.

Polanco-Ochoa, R. 1998. Estrategias sexuales, estimación poblacional y uso de hábitat de perezosos Bradypus variegatus (Xenarthra: Bradypodidae). Tesis de postgrado, Universidad Nacional de Costa Rica, Heredia, Costa Rica. 89 pp.

Slater, J. 2000. El comportamiento animal. Cambridge University Press, Madrid. 240 pp.

Sunquist, M.E. \& G.G. Montgomery. 1973. Activity patterns and rates of movement of two-toed and three-toed sloths (Choloepus hoffmanni and Bradypus infuscatus). Journal of Mammalogy 54: 946954. https://doi.org/10.2307/1379088

Urbani, B. \& C. Bosque. 2007. Feeding ecology and postural behaviour of the three-toed sloth (Bradypus variegatus flaccidus) in northern Venezuela. Mammalian Biology 72: 321-329. https://doi.org/10.1016/j. mambio.2006.10.013

Recibido: 14 de julio de 2019; Aceptado: 5 de septiembre de 2019 


\title{
SHORT COMMUNICATION
}

\section{Report of three non-agonistic encounters of free-living giant anteaters (Myrmecophaga tridactyla)}

\author{
Mariana labão Catapani ${ }^{\mathrm{A}, \mathrm{B}, 1}$, Karina Theodoro Molina ${ }^{\mathrm{C}, \mathrm{D}}$, \\ Alexandre Martins Costa Lopes $^{C}$ \& Flávia Miranda ${ }^{C}$
}

${ }^{A}$ Post-graduate Program in Environmental Science, Institute of Energy and Environment, University of São Paulo, Av. Prof. Luciano Gualberto, 1289, CEP 05508-010, São Paulo, Brazil E-mail: mariana.catapani@usp.br

${ }^{B}$ Institute for the Conservation of Wild Animals (ICAS), Rua Lino Barbosa, 142, CEP 79040-290, Campo Grande, Mato Grosso do Sul, Brazil

'Tamandua Research and Conservation Institute in Brazil, Rua do Comércio, S/N, sala 130, CEP 64200-025, Parnaíba, Piauí, Brasil E-mail: karina.molina@tamandua.org (KTM), alexandre@tamandua.org (AMCL), flavia@tamandua.org (FM)

${ }^{D}$ Post-graduate Program in Animal Science, Santa Cruz State University, CEP 45662-900, Rodovia Jorge Amado, km 16, Ilhéus, Bahia, Brazil

${ }^{1}$ Corresponding author

\begin{abstract}
The giant anteater (Myrmecophaga tridactyla) is considered a solitary species except for the reproductive and parental care periods. Agonistic encounters among giant anteaters have been previously reported, describing conflicts and fights between individuals. However, non-agonistic encounters have not been reported in the scientific literature. Three instances of such encounters were recorded: two in which two females, carrying their cubs, were foraging together for periods of a few hours, and another where a female with her cub beside her was foraging alongside an adult of unknown sex. Details of these encounters are described in this note, contributing to knowledge of the natural history of the species.
\end{abstract}

Keywords: free-living anteaters, non-agonistic encounters, solitary species

Relato de três encontros não-agonísticos entre tamanduás-bandeira (Myrmecophaga tridactyla)

Resumo O tamanduá-bandeira (Myrmecophaga tridactyla) é considerado uma espécie de hábitos solitários, com exceção da época reprodutiva e do período de cuidado parental. Encontros agonísticos entre indivíduos da espécie foram relatados anteriormente, descrevendo conflitos e brigas entre eles. No entanto, encontros não agonísticos não foram relatados na literatura científica até o momento. Três situações foram registradas: duas onde duas fêmeas, carregando seus filhotes, foram vistas forrageando juntas por períodos de algumas horas, e outra, onde uma fêmea, com seu filhote ao lado, forrageou ao lado de um indivíduo adulto de sexo desconhecido. Detalhes desses encontros estão descritos nesta nota de campo, contribuindo para o conhecimento da história natural da espécie.

Palavras-chave: encontros não agonísticos, espécie solitária, tamanduás de vida livre

Species of animals differ in social complexity (Kappeler et al., 2019) and exhibit different levels of social tolerance (Kleiman, 1994). Much of the life history of the giant anteater (Myrmecophaga tridactyla), an insectivorous mammal of the Order Pilosa, is based on the assumption that interactions between individuals are rare and occur only during the reproductive season, e.g., adult males and females engaging in mating behaviors and females caring for their young (Nowak \& Paradiso, 1983), or at other times of year when individuals engage in agonistic interactions for various reasons (Shaw et al., 1987; 


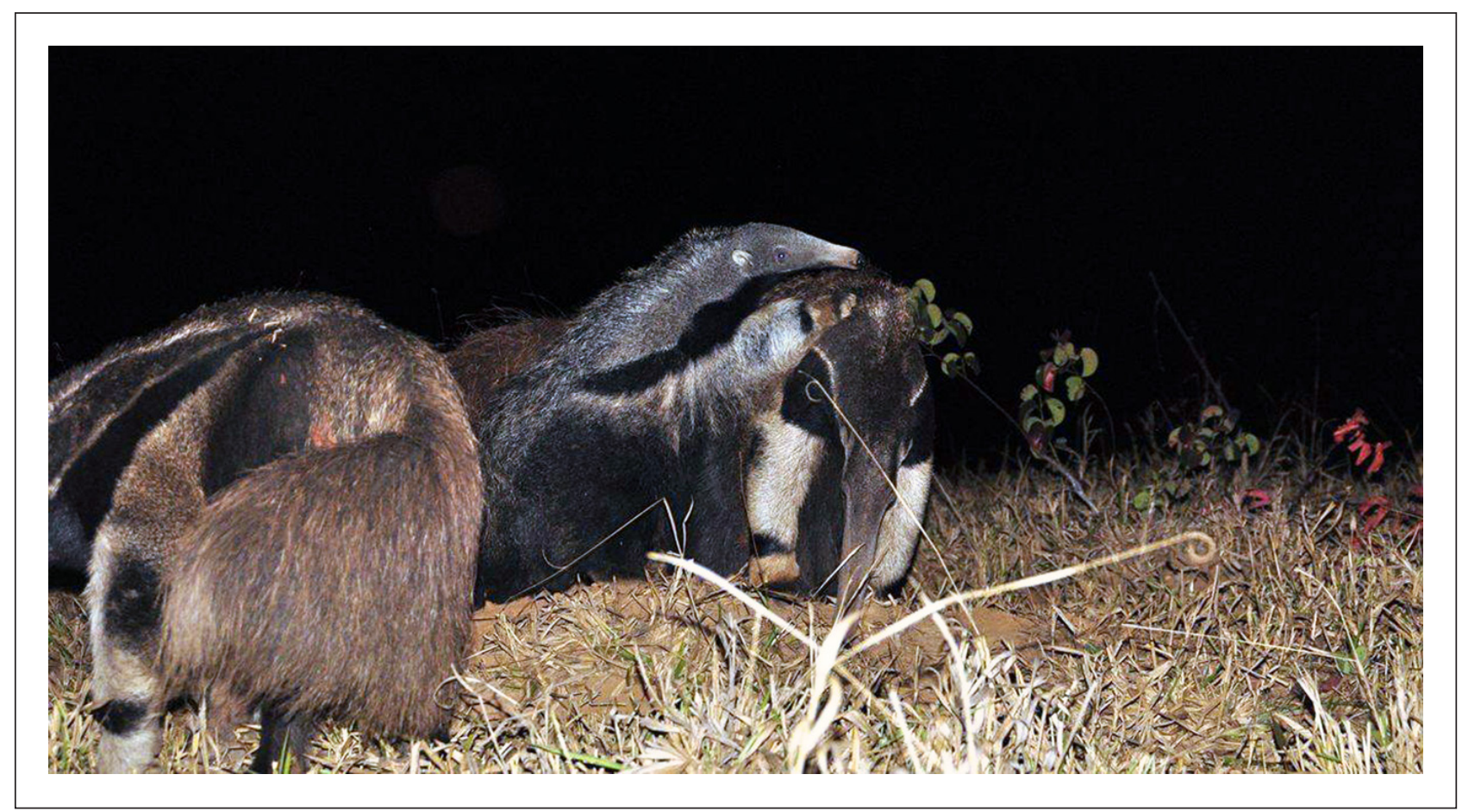

FIGURE 1. One adult female M. tridactyla with her cub (in the background) and one adult of unknown sex (foreground) observed in São Gotardo city, state of Minas Gerais, Brazil. Picture: Cyro Bernardes.

Rocha \& Mourão, 2006; Kreutz et al., 2009; Miranda Jr. \& Bertassoni, 2014). So far, non-agonistic social interactions among free-living giant anteaters have not been reported in the literature.

In this field note, we report three direct observations of non-agonistic interactions between giant anteaters: two females and their respective cubs on two occasions, and one female with her cub and an adult of unknown sex. Sexual dimorphism in giant anteaters is not evident; in the cases where we determined that the adults were females, this was based on the fact that in this species parental care is exclusively provided by females.

The first observation was made during an inventory of herpetofauna by biologist Cyro Bernardes (pers. comm.) on 17 August 2016, at 17:30 $\mathrm{hr}$ in the Cerrado area of São Gotardo city, state of Minas Gerais (19² $\left.18^{\prime} 37.80^{\prime \prime} S, 46^{\circ} 02^{\prime} 49.13^{\prime \prime} \mathrm{W}\right)$, near a dirt road between farms. Three individuals were observed: one adult female with her cub by her side and one unknown-sex adult. The three animals interacted non-aggressively, smelling one another and foraging together for about $90 \mathrm{~min}$, from dusk to full dark. After this, the cub climbed on its mother's back (FIG. 1) and they slowly walked away from the other individual.

The second observation was made on $29 \mathrm{Au}$ gust 2016, at 17:00 hr, in an open field area of the South Pantanal at the Caiman Ecological Refuge, municipality of Miranda, state of Mato Grosso do
Sul, central-western region of Brazil (19 ${ }^{\circ} 57^{\prime} 17.52^{\prime \prime}$, $\left.56^{\circ} 18^{\prime} 34.12^{\prime \prime} \mathrm{W}\right)$. A tourist on a photographic safari at the refuge sent us a photo (FIG. 2) to find out if it depicted a common situation. The photo shows two adult female $M$. tridactyla, each with a cub on the back, foraging very close to one another (FIG. 2). According to the tourist, there was no direct or agonistic interaction between the two, instead they remained side by side (proximity ranged from approximately $0.5-5 \mathrm{~m}$ ) for about $55 \mathrm{~min}$, and then moved away.

The third observation was made by Fabiano Vargas, a field assistant of the Tamandua Institute, at Fazenda São José, in the municipality of Aquidauana, Mato Grosso do Sul state $\left(20^{\circ} 05^{\prime} 44.22^{\prime \prime}\right.$, $55^{\circ} 57^{\prime} 53.57^{\prime \prime W}$ ) on 18 June 2017, at 09:00 hr. Much like the second observation just described, he observed two adult female $M$. tridactyla, each with a cub on its back, forage together (FIG. 3). The individuals sniffed and stayed close to one another for about $2 \mathrm{~h}$, then slowly moved away.

The general expectation in asocial, solitary species is that conspecifics are avoided (Barry \& Crowell-Davis, 1999). For example, field studies of several solitary species (e.g., cats [Leyhausen, 1965], weasels [Lockie, 1966]) emphasize the importance of aggression and other mechanisms promoting spacing between individuals. Giant anteaters exhibit several types of behavior consistent with expectations for a solitary species, all of which have been associated with presumed territoriality in this 


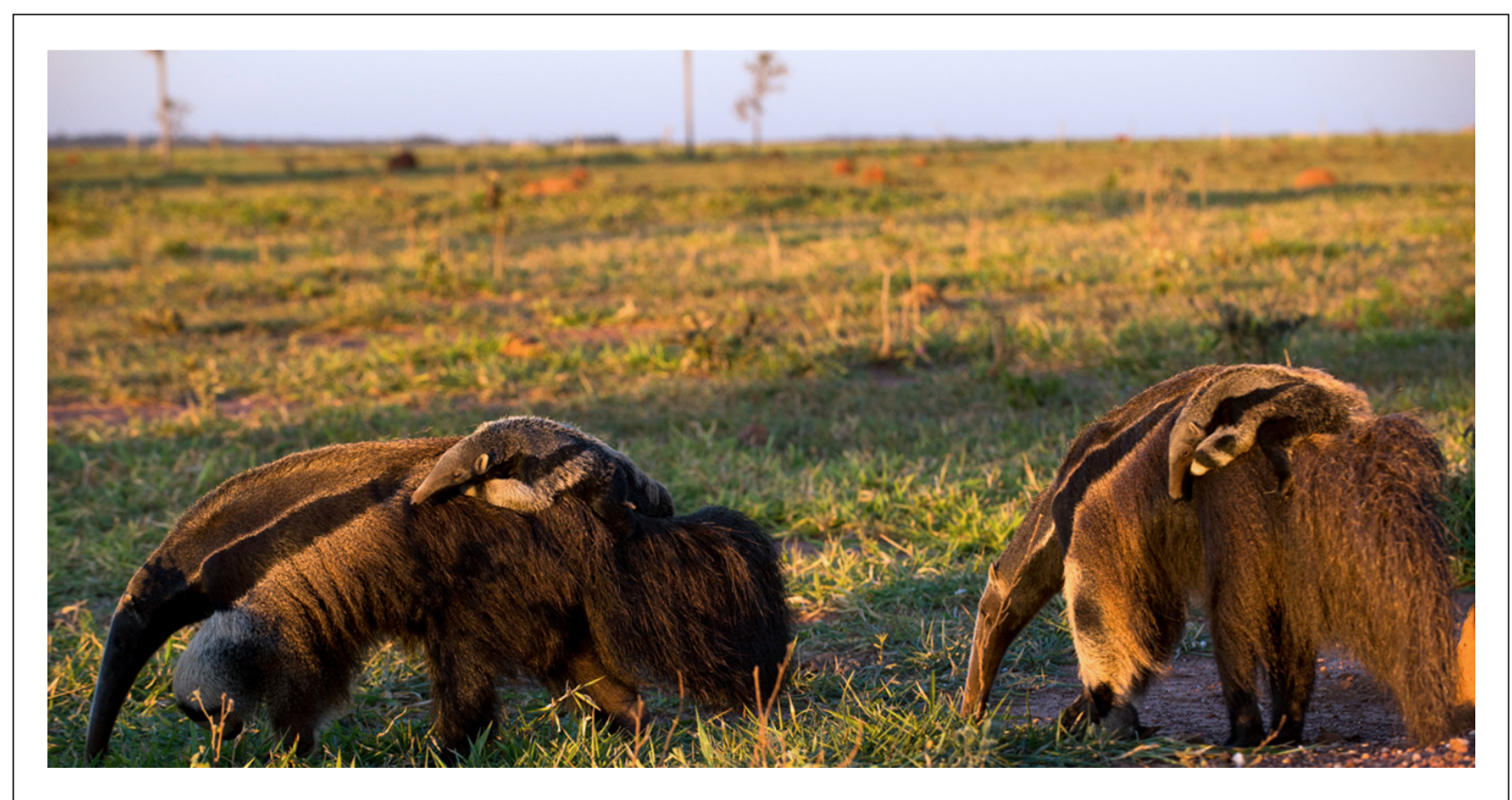

FIGURE 2. Two adult female M. tridactyla, each with a cub on its back, observed in Miranda city, state of Mato Grosso do Sul, central-western region of Brazil. Picture: tourist at Caiman Ecological Refuge.

species, such as agonistic encounters (Rocha \& Mourão, 2006; Kreutz et al., 2009; Miranda Jr. \& Bertassoni, 2014), scratch marking (Braga et al., 2010), and scent marking via urination, where the animal rubs its genitalia on a surface such as logs or rocks (F. Miranda, pers. obs.). However, classifying a species as solitary does not necessarily mean that the animals do not maintain non-hostile social interactions (Kappeler \& van Schaik, 2002). In captivity, giant anteaters and lesser anteaters (Tamandua tetradactyla) are usually pair-housed, generally two females but sometimes a male and female (except

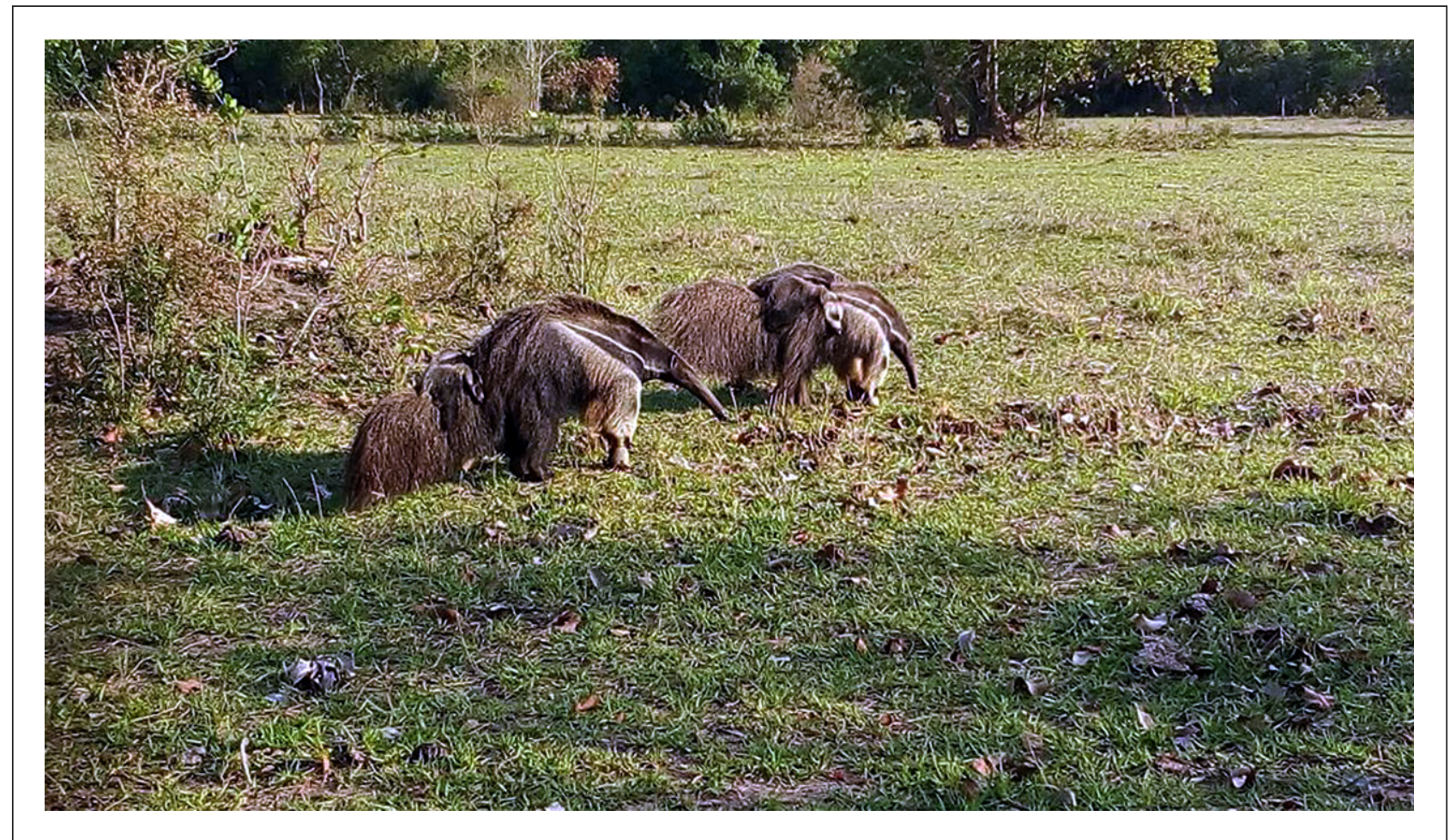

FIGURE 3. Two adult female M. tridactyla foraging together, each with a cub on its back, in Aquidauana city, state of Mato Grosso do Sul, central-western region of Brazil. Picture: Fabiano Vargas. 
if the female is caring for a cub because males can kill the cub to try to copulate with the female). According to Catapani et al. (2018), keeping lesser anteaters pair-housed, even though they are a solitary species, promotes better animal welfare than the solitary condition.

The diet of giant anteaters in the wild is composed exclusively of social insects, such as ants and termites (Montgomery, 1985). Despite being abundant, this resource is also sparsely distributed. Perhaps the feeding ecology of giant anteaters is, as with solitary orangutans (Maple, 1980), the main factor influencing their social organization. The encounters reported here may have been facilitated because female home ranges can overlap (Shaw et al., 1987; Bertassoni \& Ribeiro, 2019), thus providing opportunities for individuals to interact. Moreover, environmental characteristics should be taken into account. All of these non-agonistic encounters were recorded during the dry season (June to August) when there is a diminished availability of resources, which may bring individuals closer together at places with more food, water, and resting areas.

What determines whether an encounter between adult giant anteaters will be agonistic or non-agonistic is still poorly understood. Due to their typical solitary nature, non-agonistic interactions and conspecific tolerance among giant anteaters are important topics for research. It would be interesting to determine if variation in the availability of resources and/or giant anteater density influences the frequency of tolerance or whether it can be better explained by factors such as reciprocity or kinship.

\section{REFERENCES}

Barry, K.J. \& S.L. Crowell-Davis. 1999. Gender differences in the social behavior of the neutered indoor-only domestic cat. Applied Animal Behaviour Science 64: 193-211. https://doi.org/10.1016/S0168-1591(99)00030-1

Bertassoni, A. \& M.C. Ribeiro. 2019. Space use by the giant anteater (Myrmecophaga tridactyla): a review and key directions for future research. European Journal of Wildlife Research 65: 93. https://doi.org/10.1007/ s10344-019-1334-y

Braga, F. G., R.E.F. Santos \& A.C. Batista. 2010. Marking behavior of the giant anteater Myrmecophaga tridactyla (Mammalia: Myrmecophagidae) in southern
Brazil. Zoologia 27: 7-12. https://doi.org/10.1590/ S1984-46702010000100002

Catapani, M.L., J.S.R. Pires \& A.D.S. Vasconcelos. 2018. Single or pair-housed: which is better for captive southern tamanduas? Journal of Applied Animal Welfare Science 22: 289-297. https://doi.org/10.10 80/10888705.2018.1508352

Kappeler, P.M. \& C.P. van Schaik. 2002. Evolution of primate social systems. International Journal of Primatology 23: 707-740. https://doi.org/10.1023/ A:1015520830318

Kappeler, P.M., T. Clutton-Brock \& S. Shultz. 2019. Social complexity: patterns, processes and evolution. Behavioral Ecology and Sociobiology 73: 5. https:// doi.org/10.1007/s00265-018-2613-4

Kleiman, D.G. 1994. Mammalian sociobiology and zoo breeding programs. Zoo Biology 13: 423-432. https:// doi.org/10.1002/zoo.1430130505

Kreutz, K., F. Fischer \& K.E. Linsenmair. 2009. Observations of intraspecific aggression in giant anteaters (Myrmecophaga tridactyla). Edentata 8-10: 6-7. https://doi.org/10.1896/020.010.0107

Leyhausen, P. 1965. The communal organization of solitary mammals. Symposia of the Zoological Society of London 14: 249-263.

Lockie, J.D. 1966. Territoriality in small carnivores. Symposia of the Zoological Society of London 18: 143-164.

Maple, T.L.1980. Orangutan behavior. Van Nostrand Reinhold, New York, USA.

Miranda Jr., J.F. \& A. Bertassoni. 2014. Potential agonistic courtship and mating behaviour between two adult giant anteaters (Myrmecophaga tridactyla). Edentata 15: 69-72. https://doi.org/10.5537/020.015.0105

Montgomery, G.G. 1985. The evolution and ecology of armadillos, sloths and vermilinguas. Smithsonian Institution Press, Washington and London. $451 \mathrm{pp}$.

Nowak, R.M. \& J.L. Paradiso. 1983. Walker's mammals of the world. Johns Hopkins University Press, Baltimore. 642 pp.

Rocha, F.L. \& G. Mourão. 2006. An agonistic encounter between two giant anteaters (Myrmecophaga tridactyla). Edentata 7: 50-51. https://doi.org/10.1896/14134411.7.1.50

Shaw, J.H., J. Machado-Neto \& T.S. Carter. 1987. Behavior of free living giant anteaters (Myrmecophaga tridactyla). Biotropica 19: 255-259. https://doi. org $/ 10.2307 / 2388344$

Received: 24 July 2019; Accepted: 26 November 2019 


\title{
COMUNICACIÓN BREVE
}

\section{Reporte de un ejemplar albino de Tamandua tetradactyla (Linnaeus, 1758) (Pilosa, Myrmecophagidae) en el suroeste de Paraguay}

\author{
Sergio D. Ríos ${ }^{\mathrm{A}, 1}$, Christian Ruiz Díaz ${ }^{\mathrm{B}}$ \& Paul Smith ${ }^{\mathrm{C}}$ \\ A Departamento de Arqueología y Paleontología, Secretaría Nacional de Cultura, Asunción, Paraguay \& \\ Museo Nacional de Historia Natural del Paraguay, San Lorenzo, Paraguay \\ E-mail: sergiord40@gmail.com

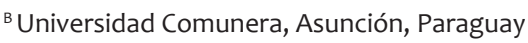 \\ 'FAUNA Paraguay, Encarnación, Paraguay, www.faunaparaguay.com; Para La Tierra, Centro IDEAL, \\ Mariscal Estigarribia 321 c/ Tte. Capurro, Pilar, dpto. Ñeembucú, Paraguay \\ ${ }^{1}$ Autor para la correspondencia
}

\begin{abstract}
Resumen Reportamos un Tamandua tetradactyla albino fotografiado en la naturaleza y proveniente del suroeste de Paraguay, departamento de Neembucú. Se trata aparentemente del primer caso documentado de albinismo en la especie y el primer registro de esta especie en el departamento de Ñeembucú.
\end{abstract}

Palabras clave: albinismo, coloración, Ñeembucú, oso melero

An albino Tamandua tetradactyla (Linnaeus, 1758) (Pilosa, Myrmecophagidae) in southwestern Paraguay

Abstract We report an albino Tamandua tetradactyla photographed in nature in southwestern Paraguay, Neembucú department. It is apparently the first documented case of albinism in this species and the first record of the species in Ñeembucú department.

Keywords: albinism, coloration, Southern tamandua, Neembucú

Las manifestaciones de polimorfismos de coloración o pigmentación son fenómenos de orígenes múltiples que ocurren en todos los grupos de vertebrados, incluyendo los mamíferos. Se clasifican, entre otros, en albinismo, melanismo y leucismo (Fox \& Vevers, 1960) dependiendo de la ausencia, baja o alta presencia de pigmentos de coloración, como la melanina (van Grouw, 2013). Estas variaciones fenotípicas han sido poco estudiadas y reportadas en la literatura científica relacionada al Neotrópico (Abreu et al., 2013). En el caso de los xenartros, las contribuciones son aún muy escasas (Xavier et al., 2010; Lopes et al., 2019).

Tamandua tetradactyla es una de las especies vivas del magnorden Xenarthra de mayor distribución, abarcando prácticamente todo el subcontinente sudamericano al oeste de los Andes y hasta el norte de Argentina (Bertassoni, 2018). Así también es uno de los xenartros más conspicuos en el Paraguay, donde se lo conoce con los nombres de oso melero o kaguare (Smith \& Ríos, 2018). La subespecie que habita el Paraguay es T. t. straminea (Cope, 1889) y ha sido registrada en casi todo el país, en diversos ambientes y ecorregiones (Smith \& Ríos, 2018). Con respecto a su estado de conservación, T. tetradactyla es una especie considerada de Preocupación Menor (Abba et al., 2017; Saldívar et al., 2017), pero sensible al cambio de uso de la tierra, a la cacería humana y a los atropellamientos por vehículos.

La coloración de T. tetradactyla a lo largo de su distribución es variable (Hayssen, 2011), pero en el Paraguay por lo general presenta un pelaje amarillo crema en la cabeza, cuello, nuca, extremidades 


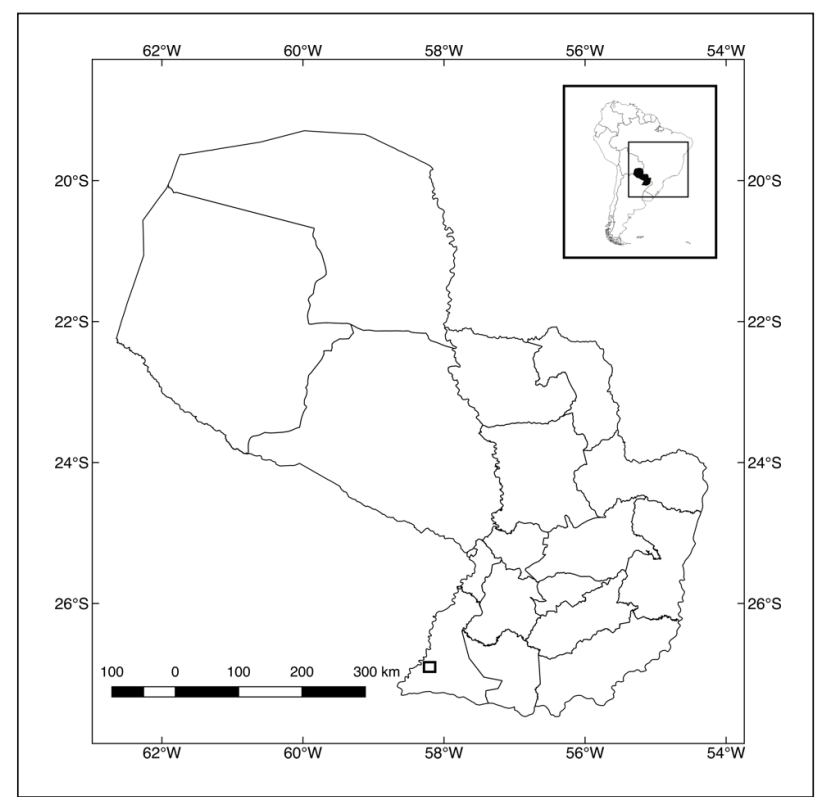

FIGURA 1. Mapa de Paraguay indicando la localización del hallazgo (cuadrado).

y cola, combinado con una notable coloración negra o marrón oscura, típicamente sobre la espalda en forma de chaleco (Smith, 2007). Existen algunas menciones de individuos melánicos de $T$. tetradactyla, como por ejemplo uno de Guyana Francesa (Menegaux, 1902) y otro de Paraguay (Cabrera, 1912). Además, las subespecies T. tetradactyla nigra (É. Geoffroy St.-Hilaire, 1803) y T. tetradactyla quichua (Thomas, 1927) (de Perú) fueron descritas a partir de ejemplares melánicos (Gardner, 2008).

En esta contribución comunicamos el hallazgo en la naturaleza de un individuo albino de T. tetradactyla, en base a una observación reciente realizada en el suroeste de Paraguay (FIG. 1, 2). El mismo correspondía a un ejemplar aparentemente adulto o casi adulto, con el pelaje sin pigmentación visible, lo que le confería un aspecto general blancuzco (FIG. 2). La piel observable en las orejas y dedos era de color rosado y el ojo visible en la fotografía notablemente rojizo. Estas características permiten postular que se trataba de un ejemplar albino y no leucístico ya que la piel y los ojos por lo general conservan un aspecto normal en animales con leucismo (Fox \& Vevers, 1960).

El registro ocurrió camino a la localidad de Isla Umbú (coordenadas aproximadas $27^{\circ} 00^{\prime} \mathrm{S}, 58^{\circ} 18^{\prime} \mathrm{W}$ ), cercana a la ciudad de Pilar, capital del departamento de Ñeembucú (FIG. 1). El 19 de junio de 2018 se fotografió al individuo en cuestión (FIG. 2) en una isleta de bosque de la zona de Paso Pindó. El departamento Neembucú pertenece a la ecorregión denominada Chaco Húmedo y se caracteriza por presentar un mosaico de esteros, palmares y bosques del tipo chaqueño (Viré \& Martínez Fretes, 2014).

Este hallazgo, además de ser el primer ejemplar albino registrado de $T$. tetradactyla, es también
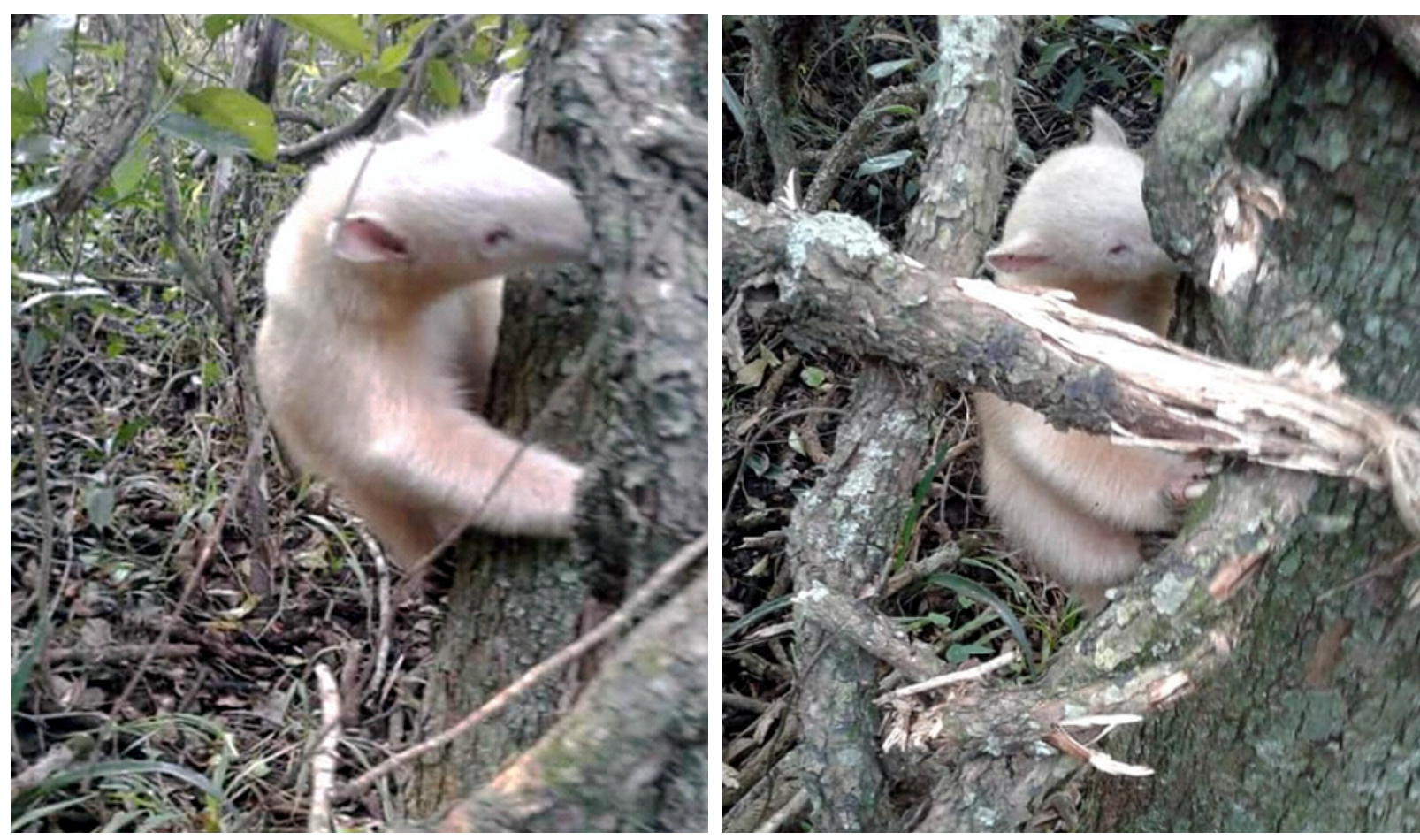

FIGURA 2. Tamandua tetradactyla en Paso Pindó, Ñeembucú, Paraguay. Fotografías: Nery Agüero. 
el primero de la especie para el departamento de Neembucú. Su presencia era inferida en la zona considerando la amplia distribución de la especie en Paraguay (Smith \& Ríos, 2018), pero hasta la fecha requería de documentación.

En el caso específico del albinismo, la falta de pigmentación en los ojos y piel constituye un factor a tener en cuenta considerando la sensibilidad de los mismos a la radiación solar (Pérez-Carpinell et al., 1992) (más aún en un país subtropical como Paraguay) y afecta seriamente la vista del animal, dejándolo casi ciego (Edmunds, 1949). Resulta importante mencionar que aparte del albinismo del ejemplar, el mismo presentaba un aspecto normal, con una apariencia robusta y aparentemente saludable, además de encontrarse aferrado a un árbol al momento de la observación, parte del comportamiento típicamente arborícola de la especie (Massoia et al., 2012). El hecho de que el individuo haya llegado a la edad adulta, o al menos cercana a ella, es también remarcable, teniendo en cuenta que se considera que una coloración distinta a la normal constituye una desventaja ante los predadores y también puede provocar ataques de conspecíficos (Møller \& Mousseau, 2001). Los mirmecofágidos en general se caracterizan por su visión limitada, con una ecología más dependiente de su sentido del olfato extremadamente desarrollado (Bertassoni, 2018), hecho que puede significar que los problemas de visión causados por el albinismo no los afecten en la manera que lo harían en otros grupos de mamíferos.

Es probable que casos de este tipo o de otras aberraciones de coloración se den con mayor frecuencia en xenartros, considerando algunas fotografías disponibles en internet pero no publicadas formalmente. Urgimos a la documentación de dichos hallazgos, para facilitar la cuantificación de la incidencia de aberraciones cromáticas en mamíferos y en particular en xenartros.

\section{AGRADECIMIENTOS}

A Nery Agüero por comunicar el hallazgo y a Frederick Bauer por sus comentarios. SDR y PS agradecen al PRONII - CONACyT por su apoyo esencial.

\section{REFERENCIAS}

Abba, A. M., S.D. Ríos \& P. Smith. 2017. Xenarthra: armadillos y osos hormigueros. Pp. 41-47 in: Libro Rojo de mamíferos del Paraguay (S. Saldívar, V. Rojas \& D. Giménez, eds.). Asociación Paraguaya de Mastozoología y Secretaría del Ambiente, Asunción, Paraguay.

Abreu, M.S., L.R. Machado, F. Barbieri, N.S. Freitas \& L.R. Oliveira. 2013. Anomalous colour in Neotropical mammals: a review with new records for
Didelphis sp. (Didelphidae, Didelphimorphia) and Arctocephalus australis (Otariidae, Carnivora). Brazilian Journal of Biology 73: 185-194. https://doi. org/10.1590/S1519-69842013000100020

Bertassoni, A. 2018. Family Myrmecophagidae. Pp. 74-90 in: Handbook of the mammals of the world. Vol 8. Insectivores, sloths and colugos (D.E. Wilson \& R.A. Mittermeier, eds.). Lynx Edicions, Barcelona.

Cabrera, A. 1912. Catálogo metódico de las colecciones de mamíferos del Museo de Ciencias Naturales de Madrid. Trabajos del Museo de Ciencias Naturales 7: 1-147.

Edmunds, R. T. 1949. Vision of albinos. Archives of Ophthalmology 42: 755-767. https://doi.org/10.1001/ archopht.1949.00900050766005

Fox, H.M. \& G. Vevers. 1960. The nature of animal colours. Macmillan, New York. 246 pp.

Gardner, A. L. 2008. MagnorderXenarthra.Pp.127-176in: Mammals of South America. Volume 1: Marsupials, xenarthrans, shrews, and bats (A.L. Gardner, ed.). The University of Chicago Press, Chicago. https:// doi.org/10.7208/chicago/9780226282428.001.0001

Hayssen, V. 2011. Tamandua tetradactyla (Pilosa: Myrmecophagidae). Mammalian Species: 43: 64-74. https://doi.org/10.1644/875.1

Lopes, A.C.P. de A., E.C. de Farias Junior, M.A. de Freitas \& K.T. Molina. 2019. Primeiro registro de leucismo em Bradypus variegatus (Schinz 1825, Xenarthra: Bradypodidae), município de Maceió, Alagoas, Brasil. Edentata 20: 39-43. https://doi. org/10.2305/IUCN.CH.2019.Edentata-20-1.8.en

Massoia, E., J. C. Chebez \& A. Bosso. 2012. Los mamíferos silvestres de la provincia de Misiones, Argentina. Fundación de Historia Natural Félix de Azara, Buenos Aires. 510 pp.

Menegaux, A. 1902. Catalogue des mammifères rapportés par M. Geay de la Guyane Francaise en 1889 et 1900. Bulletin du Muséum d'Histoire Naturelle Paris 8: 49-96.

Møller, A.P. \& T. A. Mousseau. 2001. Albinism and phenotype of Barn Swallows (Hirundo rustica) from Chernobyl. Evolution 55: 2097-2104. https://doi. org/10.1111/j.0014-3820.2001.tb01324.x

Perez-Carpinell, J., P. Capilla, C. Illueca \& J. Morales. 1992. Vision defects in albinism. Optometry and Vision Science 69: 623-628. https://doi.org/10.1097/ 00006324-199208000-00005

Saldívar, S., V. et al. 2017. Los mamíferos amenazados del Paraguay. Pp. 25-32 in: Libro Rojo de mamíferos del Paraguay (S. Saldívar, V. Rojas \& D. Giménez, eds.). Asociación Paraguaya de Mastozoología y Secretaría del Ambiente, Asunción, Paraguay.

Smith, P. 2007. FAUNA Paraguay. Southern Tamandua Tamandua tetradactyla. Handbook of the mammals of Paraguay 3: 1-5. Actualizado en abril 2012. http://www.faunaparaguay.com/mamm3Tamanduatetradactyla.pdf 
Smith, P. \& S.D. Ríos. 2018. Distribution and status of Paraguayan Xenarthra: towards a better understanding.Edentata19:1-29.https://doi.org/10.2305/ IUCN.CH.2018.Edentata-19-1.2.en

van Grouw, H. 2013. What colour is that bird? The causes and recognition of common colour aberration in birds. British Birds 106: 17-29.

Viré, S. \& G. Martínez Fretes. 2014. Departamento de Neembucú - Un enfoque socioambiental. Natura Vita, Asunción. 204 pp.
Xavier, G.A.A., M.A.B. Oliveira, A.A. Quirino \& R.A. Mota. 2010. Albinismo total em preguiças-de-garganta-marrom Bradypus variegatus (Schinz, 1825) no Estado de Pernambuco, Brasil. Edentata 11: 1-3. https://doi.org/10.1896/020.011.0101

Recibido: 13 de octubre de 2019; Aceptado: 25 de noviembre de 2019 


\title{
NOTA DE CAMPO
}

\section{Primeiro registro de leucismo em Bradypus variegatus (Schinz 1825, Xenarthra: Bradypodidae), município de Maceió, Alagoas, Brasil}

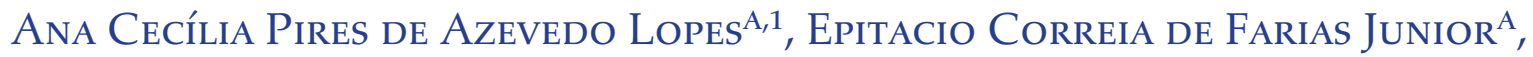 \\ Marco Antônio de Freitas $^{B}$ \& Karina Theodoro Molina ${ }^{C}$ \\ ${ }^{\text {A }}$ Gerência de Fauna, Instituto do Meio Ambiente de Alagoas - IMA-AL, CEP 57017-515, Maceió, Alagoas, Brasil \\ E-mail: anaceciliapires@hotmail.com (ACPAL), epitaciocfj@gmail.com (ECFJ)

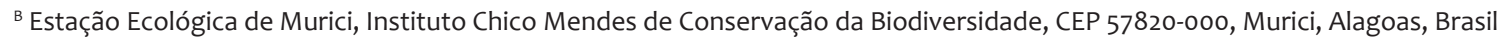 \\ E-mail: philodryas@hotmail.com \\ ' Setor de Análise Técnico-científica, Instituto de Pesquisa e Conservação de Tamanduás no Brasil, CEP 64200-025, Parnaíba, Piauí, Brasil \\ E-mail: karina.molina@tamandua.org \\ ${ }^{1}$ Autor correspondente
}

Resumo O leucismo é uma deficiência genética que consiste na perda parcial do padrão de coloração corporal. Uma preguiça-comum (Bradypus variegatus) foi encontrada em um fragmento de Mata Atlântica no Estado de Alagoas, Nordeste do Brasil. O espécime correspondia a um filhote, estando junto à mãe, e revelou leucismo restrito. O indivíduo possuía pelagem corporal branca e membros em tons de cinza claro. A pele em torno da boca e dos olhos era marrom clara e o nariz de cor negra. Aparentemente, o padrão de coloração não motivou ausência de comportamento maternal e o filhote estava visivelmente saudável. Esta nota relata o primeiro caso de leucismo em B. variegatus de vida livre.

Palavras-chave: coloração, Mata Atlântica, preguiça

First record of leucism in Bradypus variegatus (Schinz 1825, Xenarthra: Bradypodidae) from Maceió city, Alagoas, Brazil

Abstract Leucism is a genetic deficiency that results in partial loss of the coloring pattern in body hair. A juvenile brown-throated three-toed sloth (Bradypus variegatus) that exhibited restricted leucism was found (attached to its mother) in an Atlantic Forest fragment in Alagoas state, northeastern Brazil. The juvenile had white body hair, and the limbs were light gray. The skin around the mouth and eyes was light brown, and the nose black. The presence of the mother suggests the abnormal coloring pattern did not inhibit maternal behavior, and the juvenile appeared to be healthy. This field note represents the first reported occurrence of leucism in a wild B. variegatus.

Keywords: Atlantic Forest, coloring, sloth

A manifestação de polimorfismos de coloração possui uma baixa frequência de ocorrência em vertebrados, apesar de afetar uma grande quantidade de espécies (Bried et al., 2005). O leucismo é uma anomalia na pigmentação dos animais, que consiste na perda parcial do padrão de coloração corporal, exceto nos olhos e/ou nas extremidades corporais (Fertl \& Rosel, 2002). Comparando com o albinismo, este último é distinguido pela perda total da pigmentação natural do corpo e dos olhos (Abreu et al., 2013). 


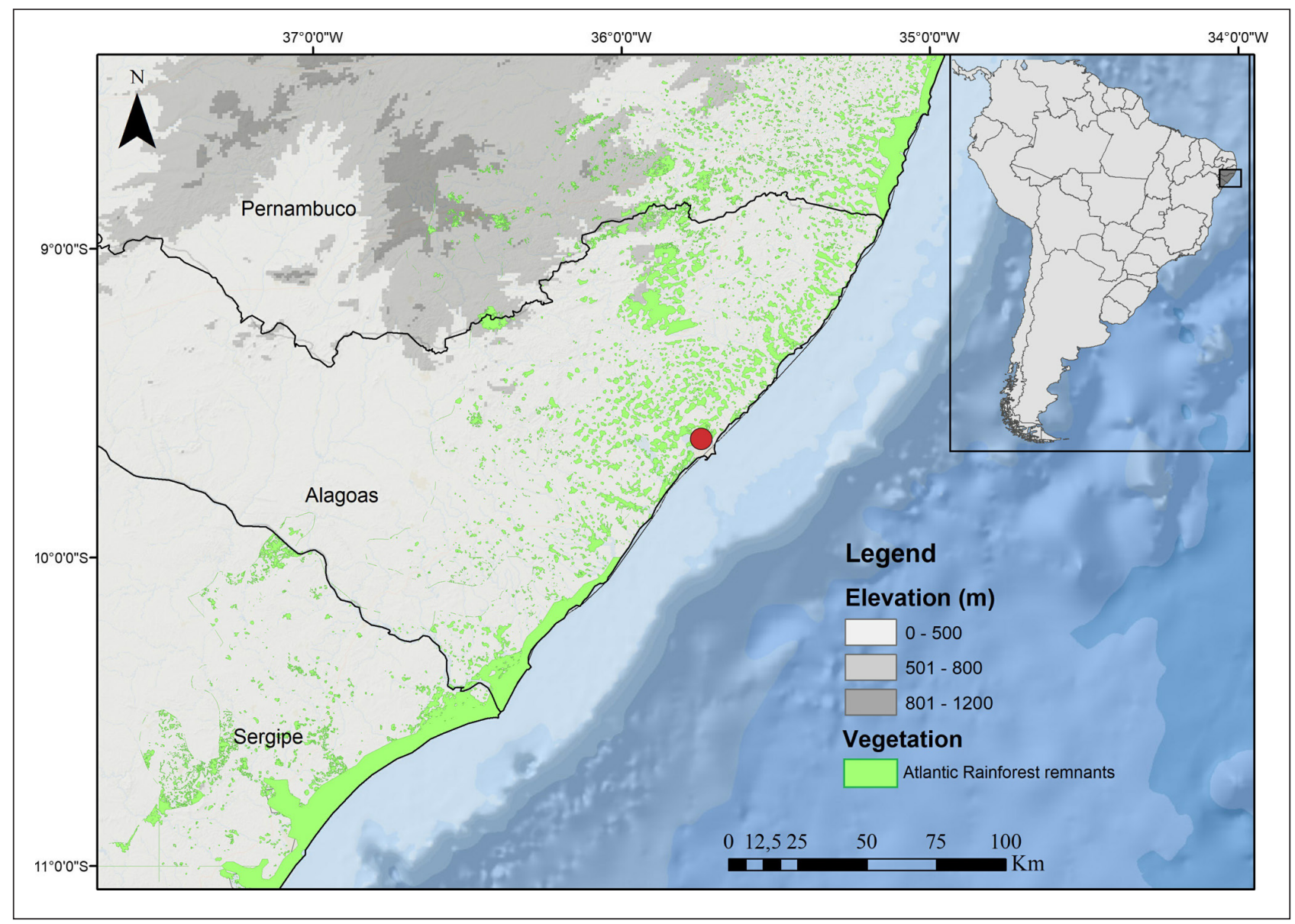

FIGURA 1. Local de registro, destacado em vermelho, da ocorrência de um filhote de Bradypus variegatus com leucismo em Maceió, Nordeste do Brasil.

Entre as variações fenotípicas hereditárias, o leucismo tem sido registrado em peixes (Veena et al., 2011), anfíbios (Mitchell \& Church, 2002), répteis (Krecsák, 2008; Noronha et al., 2013), aves (Nogueira \& Alves, 2011) e mamíferos (Cronemberger et al., 2018). Na Classe Mammalia há registros de leucismo em famílias como as Pinnipedia, Canidae, Didelphidae, Felidae (Acevedo \& Aguayo, 2008; López-González, 2011; Valle et al., 2013; Cronemberger et al., 2018), entre outras.

A família Bradypodidae é representada por três espécies do gênero Bradypus no Brasil: B. tridactylus, B. torquatus e B. variegatus. A característica comum entre elas é possuir três dedos, que diferem do gênero Choloepus, que possuem somente dois (Wetzel, 1985). A espécie B. variegatus possui pelos longos e densos, de tonalidade acinzentada, em grande parte do corpo. A pelagem frontal é clara, ressaltando uma faixa escura (preta) que contorna a boca e os olhos, se alongando na direção posterior (Wetzel, 1985). Os membros são compridos com pés e mãos estreitos, três unhas alongadas e curvadas e corpo curto, com massa muscular reduzida (Miranda \& Costa, 2007).
O presente estudo relata o primeiro caso de leucismo em preguiça-comum (B. variegatus) do Brasil. Em janeiro de 2017 foi registrado através de observação direta um filhote da espécie com coloração predominantemente esbranquiçada, identificado junto da sua mãe em um fragmento florestal de Mata Atlântica do município de Maceió, Nordeste do Brasil (9 $9^{\circ} 36^{\prime} 56,13$ "S, 35 $44^{\prime} 28,24 " W ;$ Fig. 1). O animal possuía pelagem branca na área central do corpo, com os membros anteriores e posteriores em tons de cinza claro. A faixa que contorna a boca e os olhos possuía coloração marrom clara e apenas a ponta do nariz e os olhos possuíam coloração escura (FIG. 2).

Mãe e filhote foram encontrados em posição de descanso sob uma jaqueira (Artocarpus heterophyllus) ao final da manhã e foi constatada a diferença de coloração da pelagem de ambos. Somente ao final da tarde, a mãe carregando o filhote desceu para defecar, quando o registro foi realizado (FIG. 3). Não houve captura do animal para evitar o estresse. Após a deposição de fezes, a mãe retornou à copa da árvore carregando o filhote nas costas.

Alguns autores consideram o leucismo como uma desvantagem que pode ser um fator deter- 
minante para sobrevivência do indivíduo e pouco se sabe sobre as condições associadas a essa redução de pigmentação para o animal (Jogahara et al., 2008). Devido a esta coloração, a visibilidade do animal pode ser maior para possíveis predadores, o que pode acarretar em maior pressão de seleção (Jogahara et al., 2008). Apesar das possíveis desvantagens, existem registros de alguns indivíduos que alcançaram a fase adulta e, consequentemente, a fase reprodutiva (Acevedo \& Aguayo, 2008). Alguns estudos, com mamíferos leucísticos em diferentes fases de vida, indicaram que a alteração na coloração pode não afetar a sobrevivência de alguns espécimes (Acevedo \& Aguayo, 2008; Valle et al., 2013).

As causas de leucismo são muitas vezes atribuídas à expressão de alelos mutantes (Bensch et al., 2000), os quais estão relacionados com a falta de produção de tirosinase, fazendo com que o corpo não realize a síntese da melanina, responsável pela coloração da pele ou pelos (Krecsák, 2008). Estudos genéticos em felídeos demonstraram que o leucismo está associado a disfunções e mutações genéticas causando polimorfismos de coloração (Cho et al., 2013). As variações fenotípicas, em consequência a estas alterações genéticas, frequentemente tem sido observadas em espécies gregárias ou sedentárias e podem ser mais comuns em populações

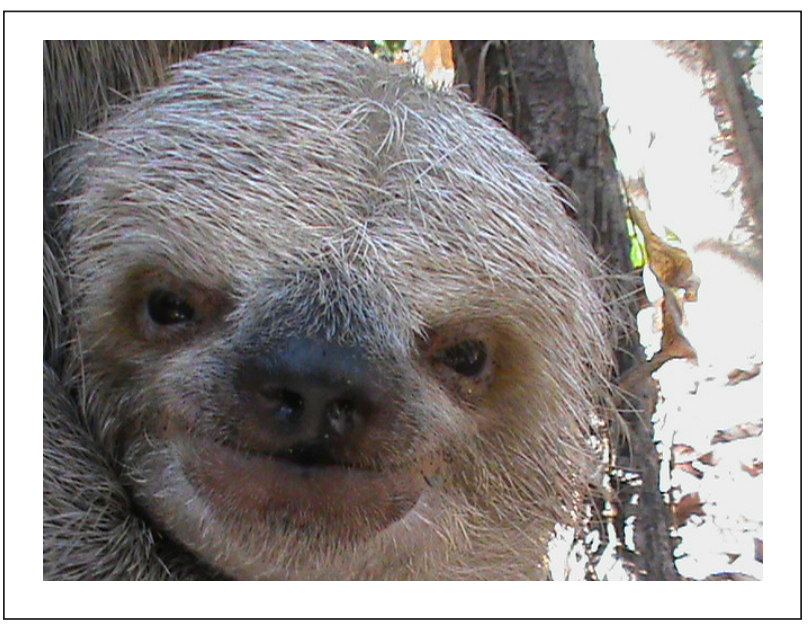

FIGURA 2. Filhote de preguiça-comum (Bradypus variegatus) com leucismo registrado em Maceió, Brasil. Observar ponta do nariz e olhos escuros, ausência da linha escura das laterais dos olhos e coloração rosada da pele no contorno dos olhos e lábios.

pequenas ou ilhadas (Bensch et al., 2000), devido a endogamia, que aumenta a probabilidade da expressão de alelos recessivos (Cronemberger et al., 2018).

As preguiças não necessitam de áreas de vida muito extensas quando comparadas a mamíferos

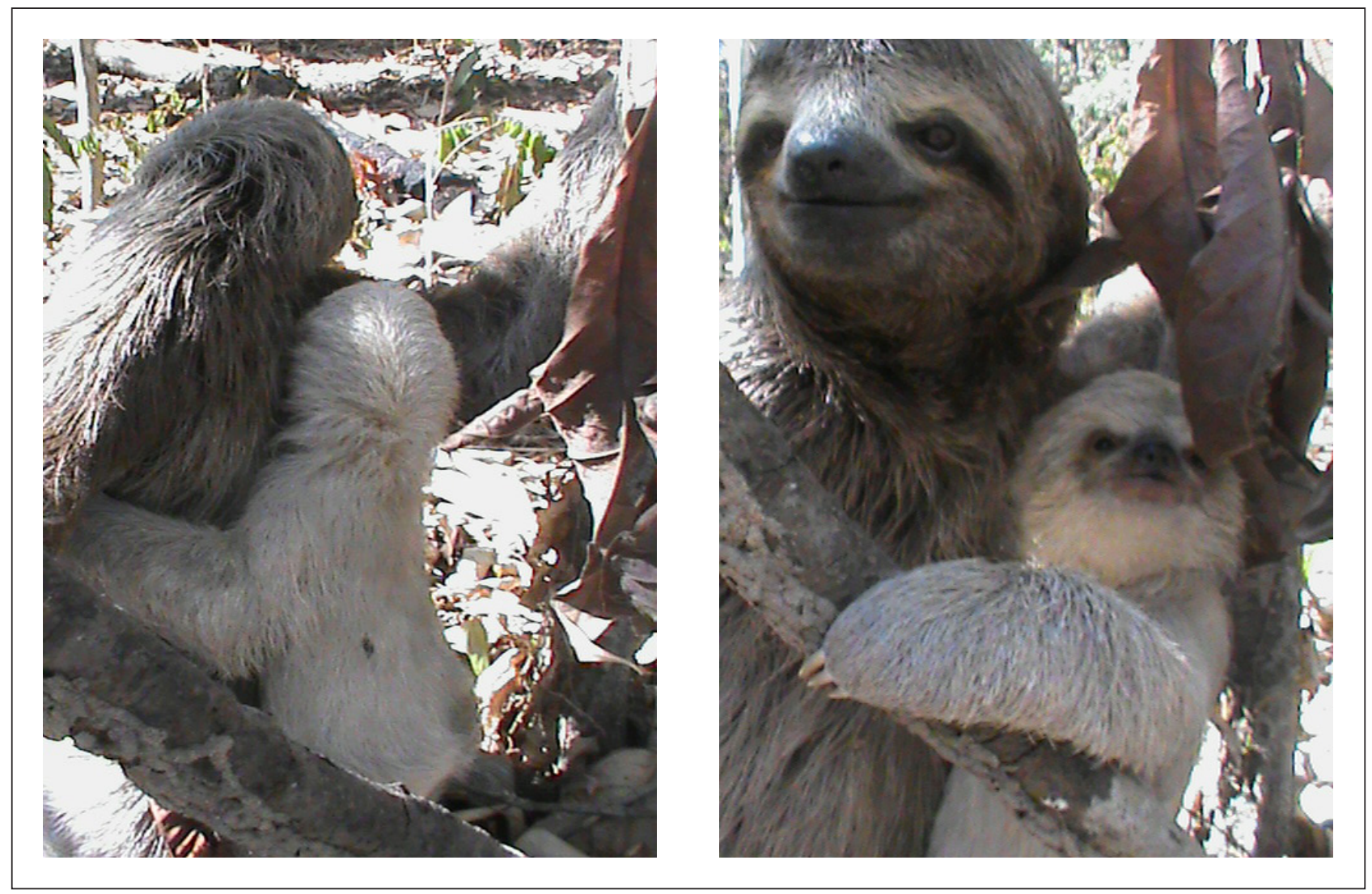

FIGURA 3. Distinção de coloração de pele e pelagem da mãe e de seu filhote da espécie Bradypus variegatus, em Maceió, Brasil. 
de mesmo tamanho corporal. Estudos sobre tamanho de área de vida de B. variegatus foram relatados com média de 1,6 ha por Montgomery \& Sunquist (1975) e de 0,9 ha por Queiroz (1995). Tal fato pode ser explicado pela baixa taxa de metabolismo basal (Nagy \& Montgomery, 1980), dieta folívora (Chiarello, 1998) e regulação da temperatura corpórea evitando a realização de atividades em temperaturas extremas (Camilo-Alves \& Mourão, 2006). Entretanto, pouco se sabe sobre os fatores que determinam sua extensão e a intensidade de uso de regiões das áreas de vida. Vistas estas características, populações que sobrevivem em pequenas áreas podem desenvolver depressão endogâmica devido à baixa variabilidade genética (Chiarello et al., 2004).

Bradypus variegatus é considerada a espécie de preguiça mais comum em território brasileiro, adaptando-se a diferentes tipos de vegetação (MMA, 2014). Somente este caso de leucismo foi registrado até o momento, podendo indicar um padrão de frequências muito baixas dos alelos responsáveis por estas condições de coloração (Cronemberger et al., 2018).

O presente relato é o primeiro registro de leucismo em B. variegatus, bem como na família Bradypodidae. Informações adicionais sobre a ecologia e genética são necessárias para avaliar se esta condição tem alguma implicação para a sobrevivência do indivíduo ou conservação das populações.

\section{AGRADECIMENTOS}

Ao Instituto do Meio Ambiente do Estado de Alagoas (IMA-AL), ao Instituto Brasileiro do Meio Ambiente e dos Recursos Naturais Renováveis (IBAMA-AL) e a Arthur Abegg.

\section{REFERÊNCIAS}

Abreu, M.S., L. R. Machado, F. Barbieri, N.S. Freitas \& L.R. Oliveira. 2013. Anomalous colour in Neotropical mammals: a review with new records for Didelphis sp. (Didelphidae, Didelphimorphia) and Arctocephalus australis (Otariidae, Carnivora). Brazilian Journal of Biology 73: 185-194. https://doi.org/10.1590/ S1519-69842013000100020

Acevedo, J. \& M. Aguayo. 2008. Leucistic South American sea lion in Chile, with a review of anomalously color in otariids. Revista de Biología Marina y Oceanografía 43: 413-417. https://doi.org/10.4067/ S0718-19572008000200017

Bensch, S., B. Hansson, D. Hasselquist \& B. Nielsen. 2000. Partial albinism in a semi-isolated population of great reed warblers. Hereditas 133: 167-170. https:// doi.org/10.1111/j.1601-5223.2000.t01-1-00167.x

Bried, J., H. Fraga, P. Calabuig-Miranda \& V.C. Neves. 2005. First two cases of melanism in Cory's Shearwater Calonectris diomedea. Marine Ornithology 33: 19-22.
Camilo-Alves, C.S. \& G.M. Mourão. 2006. Responses of a specialized insectivorous mammal (Myrmecophaga tridactyla) to variation in ambient temperature. Biotropica 38: 52-56. https://doi. org/10.1111/j.1744-7429.2006.00106.x

Chiarello, A.G. 1998. Diet of the Atlantic Forest maned sloth Bradypus torquatus (Xenarthra: Bradypodidae). Journal of Zoology 246: 11-19. https://doi. org/10.1017/S0952836998009029

Chiarello, A.G., D.J. Chivers, C. Bassi, M.A.F. Maciel, L.S. Moreira \& M. Bazzalo. 2004. A translocation experiment for the conservation of maned sloths, Bradypus torquatus (Xenarthra, Bradypodidae). Biological Conservation 118: 412-430. https://doi. org/10.1016/j.biocon.2003.09.019

Cho, Y.S. et al. 2013. The tiger genome and comparative analysis with lion and snow leopard genomes. Nature Communications 4: 2433. https://doi. org/10.1038/ncomms3433

Cronemberger, C., F. A. Pereira, A.E.F. Bacellar \& L. G. Silva. 2018. First record of leucism in puma from Serra dos Órgãos National Park, Brazil. Cat News 68: $38-40$.

Fertl, D. \& P. Rosel. 2002. Albinism. Pp. 24-26 in: Encyclopedia of marine mammals, Vol. 2 (W.F. Perrin, B. Würsig \& J.G.M. Thewissen, eds.). Academic Press, San Diego. https://doi.org/10.1016/ B978-0-12-373553-9.00006-7

Jogahara, T., G. Ogura, G. Higa, O. Ishibashi \& S. Oda. 2008. Survey and capture of albino-like house musk shrews (Suncus murinus) in Okinawa, Japan, and a preliminary report regarding inheritance of the albino-like mutation. Mammal Study 33: 121-124. https://doi.org/10.3106/1348-6160(2008)33[121:SACOAH]2.0.CO;2

Krecsák, L. 2008. Albinism and leucism among European Viperinae: a review. Russian Journal of Herpetology 15: 97-102.

López-González, C. A. 2011. Registro de un coyote (Canis latrans) blanco en el Desierto Chihuahuense de Durango, México. Acta Zoológica Mexicana 27: 871873. https://doi.org/10.21829/azm.2011.273791

Miranda, F. R. \& A. M. Costa. 2007. Xenarthra (tamanduá, tatu, preguiça) - capítulo 26. Pp. 402-414 in: Tratado de animais selvagens, medicina veterinária (Z.S. Cubas, J.C.R. Silva \& J.L. Catão-Dias, eds.). Roca, São Paulo.

Mitchell, J.C. \& D.R. Church. 2002. Leucistic marbled salamanders (Ambystoma opacum) in Virginia. Banisteria 20: 67-69.

MMA - Ministério do Meio Ambiente do Brasil. 2014. Avaliação de risco de extinção dos xenartros brasileiros. MMA/IBAMA. 250 pp.

Montgomery, G.G. \& M.E. Sunquist. 1975. Impact of sloths on Neotropical forest energy flow and nutrient cycling. Pp. 69-98 in: Tropical ecology systems: trends in terrestrial and aquatic research (F. B. Golley \& E. Medina, eds.). Springer-Verlag, Berlin. https:// doi.org/10.1007/978-3-642-88533-4_7 
Nagy, K.A. \& G.G. Montgomery. 1980. Field metabolic rate, water flux, and food consumption in three-toed sloths (Bradypus variegatus). Journal of Mammalogy 61: 465-472. https://doi.org/10.2307/1379840

Nogueira, D.M. \& M.A.S. Alves. 2011. A case of leucism in the burrowing owl Athene cunicularia (Aves: Strigiformes) with confirmation of species identity using cytogenetic analysis. Zoologia 28: 53-57. https:// doi.org/10.1590/S1984-46702011000100008

Noronha, J.C., A. B. Barros, R. M. Miranda, E.J. Almeida \& D.J. Rodrigues. 2013. Record of leucism in Pseudoboa nigra (Serpents: Dipsadidae) in southern Amazon, Brazil. Herpetology Notes 6: 81-82.

Queiroz, H. L. 1995. Preguiças e guaribas: os mamíferos folívoros arborícolas do Mamirauá. Sociedade Civil Mamirauá/MCT - CNPq, Tefé. 160 pp.
Valle, L.G.E., J.J.S. Buchaim, C.H. Zawazki \& V.A. de Lima. 2013. Colorações anômalas em Didelphis albiventris (Didelphimorphia, Didelphidae) em um fragmento de Mata Atlântica de interior no oeste do estado do Paraná, Brasil. Caderno de Pesquisa, série Biologia 25: 58-67.

Veena, S., S. Thomas, S. G. Raje \& N.R. Durgekar. 2011. Case of leucism in the spadenose shark, Scoliodon laticaudus (Müller and Henle, 1838) from Mangalore, Karnataka. Indian Journal of Fisheries 58: 109-112.

Wetzel, R.M. 1985. The identification and distribution of recent Xenarthra (= Edentata). Pp. 5-21 in: The evolution and ecology of armadillos, sloths, and vermilinguas (G.G. Montgomery, ed.). Smithsonian Institution Press, Washington and London.

Recebido em: 24 dejaneiro de 2019; Aceito em: 31 de julho de 2019 
Edentata 20 (2019): 44-46 DOI: 10.2305/IUCN.CH.2019.Edentata-20-1.9.en Electronic version: ISSN 1852-9208 Print version: ISSN 1413-4411 http://www.xenarthrans.org

\section{News}

\section{WE HAVE A NEW WEBSITE!}

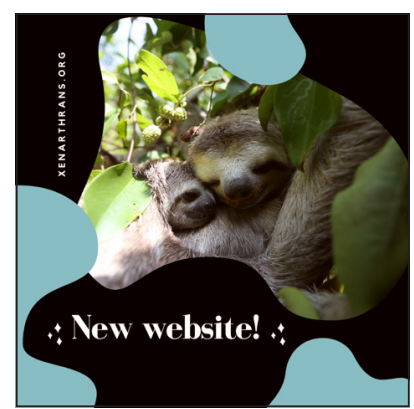

Thanks to a grant from the Species Survival Commission (SSC) we have completely redesigned our Specialist Group website (www. xenarthrans.org) and included plenty of beautiful pictures of xenarthrans. The texts in English, Spanish, and Portuguese have been updated to reflect, among others, the recent taxonomic changes. Its responsive design ensures that the content is automatically adjusted to different display sizes, such as smartphones and tablets.

Huge thanks to the IUCN SSC for the financial support; to all colleagues who have helped update and review the texts; to the fabulous photographers who donated their pictures; and to Sofia Silveira Lauz and her team at Tecnomunay for the beautiful design!

\section{OUR CHAIR AND RED LIST AUTHORITY COORDINATOR ATTENDED THE $4^{\mathrm{TH}}$ IUCN SSC LEADERS' MEETING}

Our Specialist Group Chair Mariella Superina and our Red List Authority Coordinator Agustín M. Abba attended the $4^{\text {th }}$ IUCN SSC Leaders' Meeting,

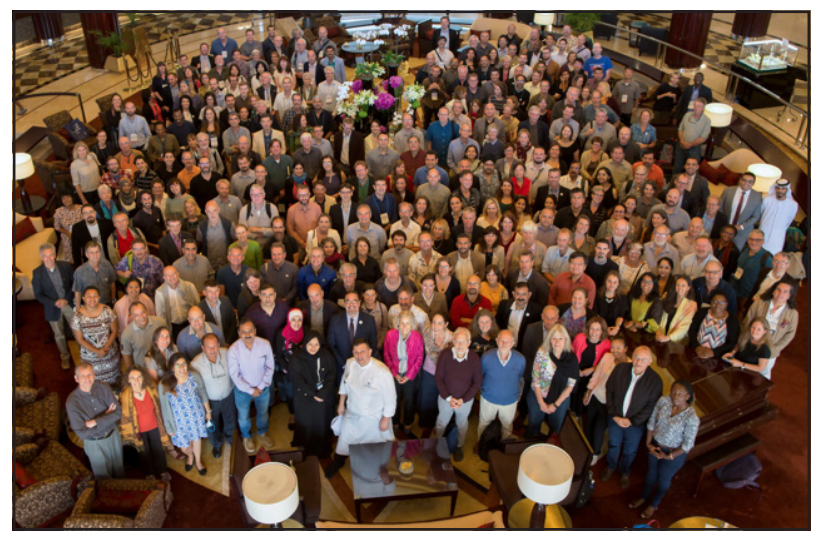

which was held from October 6 to 11 in Abu Dhabi, United Arab Emirates. During four very productive and intense days, they attended training sessions, discussions, and symposia about a wide range of topics that will help our Specialist Group to improve its effectiveness and impact in conservation. This conference, organized by the IUCN Species Survival Commission (SSC) in alliance with the Environment Agency Abu Dhabi (EAD), brought together more than 350 conservation experts, so Mariella and Agustín also had the opportunity to exchange ideas and experiences with many other Specialist Group leaders. Huge thanks to Environment Agency Abu Dhabi for making this incredibly inspiring and motivating meeting possible!

\section{IUCN CALLS FOR HALT TO SPECIES DECLINE BY 2030}

IUCN has issued an urgent call to massively scale up species conservation action in response to the escalating biodiversity crisis. The Abu Dhabi Call for Global Species Conservation Action appeals to the world's governments, international agencies and the private sector to halt species decline and prevent human-driven extinctions by 2030, and to improve the conservation status of threatened species with a view to bringing about widespread recovery by 2050 . For additional information, please visit https://www.iucn.org/news/ species-survival-commission/201910/iucn-calls-haltspecies-decline-2030. The Abu Dhabi Call for Global Species Conservation Action can be found here: https://www.iucn.org/sites/dev/files/content/documents/the_abu_dhabi_call_for_global_species_conservation_action_adopted_01112019.pdf

\section{OUTSTANDING CAREER AWARD FOR SERGIO F. VIZCAÍNO}

Specialist Group Member Sergio F. Vizcaíno received this year's Outstanding Career Award from the Argentinean Society for the Study of Mammals (SAREM by its Spanish acronym). Sergio obtained 
his degree in biology from La Plata University, Argentina. In 1990 he successfully defended his doctoral thesis on the anatomy, systematics, and evolution of extant and fossil armadillos. During his career he has carried out numerous research projects, mainly on the paleobiology of South American mammals. His findings have advanced our understanding of the biology of extant and extinct mammals from a biomechanical, morphofunctional, and ecomorphological viewpoint. The Xenarthra have always played a special role in Sergio's research. Among others, studying the biomechanical aspects of extant Xenarthra allowed him to infer the lifestyle of extinct species.

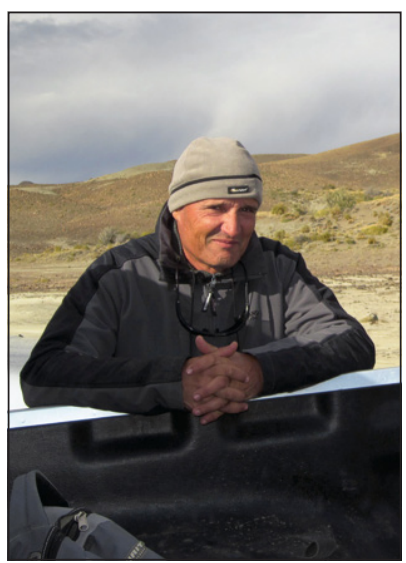

Sergio has inspired, encouraged, and trained a whole generation of mammalogists and paleontologists (including several Specialist Group members) through an important number of undergraduate and graduate courses and as advisor or co-advisor of more than a dozen graduate students, seven postdocs and five early-career researchers. He is the author of a long list of scientific publications, books and book chapters. Among others, he is one of the editors of the X-book (Vizcaíno, S.F. \& W.J. Loughry (2008): The biology of the Xenarthra. University Press of Florida, Gainesville).

Sergio has been a member of our Specialist Group since 1997. His ample knowledge of the biological aspects of the Xenarthra throughout their evolutionary history allowed him to build a bridge between paleobiology and mammalogy, which has widened our vision of the conservation of extant xenarthrans.

\section{¡Felicitaciones, Sergio!}

\section{IUCN WORLD CONSERVATION CONGRESS 2020}

Held once every four years, the IUCN World Conservation Congress brings together several thousand leaders and decision-makers from government, civil society, indigenous peoples, business, and academia, with the goal of conserving the environment and harnessing the solutions nature offers to global challenges.

The Congress, which will take place on 11-19 June 2020 in Marseille, France, aims to improve how we manage our natural environment for human, social, and economic development, but this cannot be achieved by conservationists alone. The IUCN

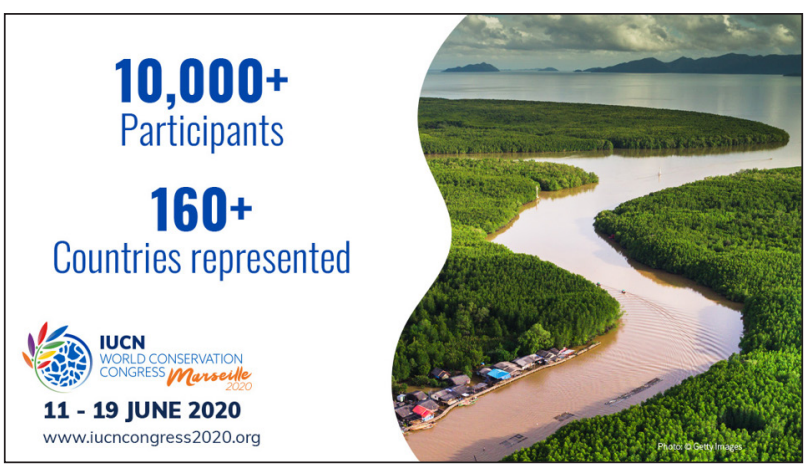

World Conservation Congress is where the world comes together to set priorities and drive conservation and sustainable development action. IUCN's $1300+$ government, civil society, and indigenous peoples' Member organizations vote on major issues, action which guides humanity's relationship with our planet for the decades ahead.

The IUCN Congress is the place to put aside differences and work together to create good environmental governance, engaging all parts of society to share both the responsibilities and the benefits of conservation.

IUCN World Conservation Congress

One nature, one future

Read more here: https://www.iucncongress2020.org/

\section{NEW PAPER ON MANED SLOTHS IDENTIFIES THEIR HABITAT REQUIREMENTS IN FRAGMENTED AREAS}

A recent study by Paloma Marques Santos and her colleagues assessed determinants of the occurrence of maned sloths (Bradypus torquatus) in the lower montane region of Espírito Santo, eastern Brazil. Based on the habitat variables they measured at 68 sites, along with presence and absence data,

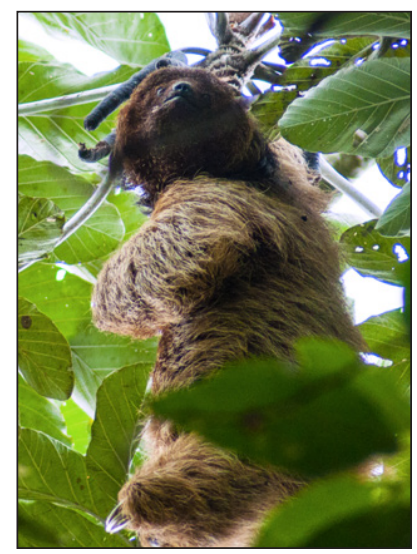
they used occupancy models and model selection methods to identify the influence of different predictors and the existence of a habitat threshold for the occurrence of this endangered sloth. The occupancy probability of the maned sloth was very high (0.97), but it decreased abruptly at 35\% of forest cover, reaching zero in areas with less than 20\% of forest cover. Open areas negatively influenced maned sloth occupancy. The results of this study imply that the conservation of maned sloths will benefit from an increase in the amount of native forest at the landscape scale. Given the difficulties 
in the creation of new public protected areas, this improvement could be achieved via restoration of areas located on private properties, which are protected by the Brazilian Forest Code.

Santos, P.M., L.L. Bailey, M.C. Ribeiro, A.G. Chiarello \& A.P. Paglia. 2019. Living on the edge: Forest cover threshold effect on endangered maned sloth occurrence in Atlantic Forest. Biological Conservation 240: 108264. https://doi.org/10.1016/j.bio con.2019.108264

\section{THE RED List OF THREATENEd MAMmals OF ARGENTINA HAS BEEN UPDATED}
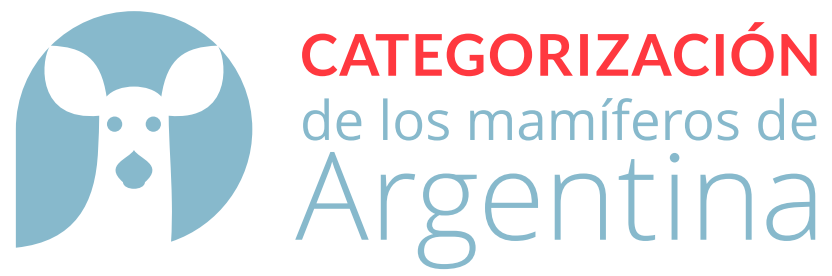

After many months of intense work, the updated Red List of Threatened Mammals of Argentina was launched on 13 November 2019.

A total of 417 species of mammals were assessed, three of which are Extinct (EX); 2 are Regionally Extinct (RE); 98 are listed in a threatened category (VU, EN, CR); 40 are Near Threatened (NT); and 78 are Data Deficient (DD). One species, Tremarctos ornatus, was Not Evaluated (NE), and 16 species, including Bradypus variegatus and Dasypus septemcinctus, were deemed to be ineligible for assessment at a regional level and thus listed as Not Applicable (NA).

The re-assessment of the Xenarthra was coordinated by our Red List Authority Agustín M. Abba, who was also one of the general coordinators of the entire re-assessment, and our Chair Mariella Superina. The most threatened xenarthran in Argentina is Priodontes maximus, which is listed as Endangered. Myrmecophaga tridactyla is categorized as Vulnerable, and six xenarthrans (Tamandua tetradactyla, Dasypus hybridus, Cabassous chacoensis, C. tatouay, Tolypeutes matacus, and Zaedyus pichiy) are listed as Near Threatened.

The re-assessment process was coordinated by Argentina's Secretary of Environment and Sustainable Development (SAyDS) and the Argentinean Society for the Study of Mammals (SAREM), and involved about 380 specialists. Thanks to its approval through an official resolution, the updated regional Red List will directly translate into public policies that favor the management and conservation of mammals at the state level.

The Red List of Threatened Mammals of Argentina is available at http://cma.sarem.org.ar

\section{THE FIRST STAGE OF THE BRAZILIAN THREE-BANDED ARMADILLO CONSERVATION PROGRAM HAS CONCLUDED}

Four years ago Associação Caatinga, in partnership with Fundação Grupo Boticário, launched the Brazilian Three-banded Armadillo Conservation Program. The project aimed to develop social and environmental initiatives for Tolypeutes tricinctus in regions where Conservation Units could be created. The first stage of the Program concluded this year, but there is still a lot of work to do to ensure the long-term conservation of this charismatic species!

The Armadillo Conservation Program is part of the National Action Plan for the Conservation of Three-banded Armadillos, a federal public policy created in 2014 with the support of Instituto Chico Mendes de Conservação da Biodiversidade (ICMBio). The Action Plan establishes 38 actions to reduce the risk of extinction of Tolypeutes tricinctus. Six of them were addressed by Associação Caatinga thanks to the financial support of Fundação Grupo Boticário. Among others, over 30 expeditions were made to document the area of occurrence of the species and to in-

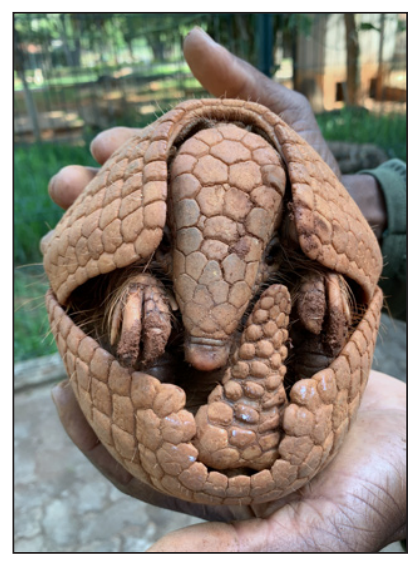
terview local communities about three-banded armadillos. Schools and communities were visited during these expeditions to raise awareness. Biological data on this rare species were collected during two scientific expeditions to the Poti River Canyon, a geological crevice located in the Ibiapaba mountain range, on the border of the states of Piauí and Ceará. The collected data helped to create the 6,872 ha Poti River Canyon State Park in Piauí state.

Although listed as Vulnerable on the IUCN Red List of Threatened Species, more pessimistic projections conclude that Tolypeutes tricinctus may disappear within 50 years. Associação Caatinga, our Specialist Group, and other institutions will therefore continue working hard to save the Brazilian Three-banded Armadillo from extinction! 


\section{NOTES TO CONTRIBUTORS}

Edentata is the official, peer-reviewed, annual publication of the IUCN/SSC Anteater, Sloth and Armadillo Specialist Group. It aims to publish information that contributes to the conservation of xenarthrans.

A broad range of topics is welcomed and encouraged but only manuscripts that make substantial contributions to the conservation of xenarthrans will be accepted. These topics include taxonomy, systematics, genetics, biogeography, ecology, conservation, behavior, and health. Manuscripts must describe original research findings that have not been published or submitted simultaneously to other journals. Any overlap of contents with already published papers should be minimal. Edentata also encourages submission of short communications, field notes, thesis abstracts, news items, recent events, book reviews, congress announcements, and the like.

Manuscripts may be written in English, Portuguese or Spanish. Authors whose first language is not English should please have their texts carefully reviewed by a native English speaker.

Once the manuscript has been received, the editors will perform a first evaluation. Manuscripts not satisfying the editorial instructions will be returned to the authors without review. Manuscripts judged appropriate by the editors are subjected to peer review. The formal review process is performed by at least two reviewers per manuscript who are not members of the editorial committee.

Detailed instructions to authors are available on the Specialist Group's webpage https://www.xenarthrans.org/edentata-newsletter/.

\section{PAUTAS PARA LOS COLABORADORES}

Edentata es la publicación oficial, anual y revisada por pares del Grupo de Especialistas en Osos Hormigueros, Perezosos y Armadillos de la IUCN/SSC (IUCN/SSC Anteater, Sloth and Armadillo Specialist Group). Está dedicada a la difusión de información que contribuya a la conservación de los xenartros.

Se aceptan manuscritos que se encuentren dentro de una amplia variedad de temáticas, pero que hagan sustanciales aportes a la conservación, incluyendo: taxonomía, sistemática, genética, biogeografía, ecología, conservación, comportamiento y salud. Los manuscritos deben ser trabajos originales y no haber sido publicados ni enviados simultáneamente a otros medios de publicación. La superposición de contenidos con artículos relacionados ya publicados debe ser mínima. También se alienta el envío de comunicaciones breves, notas de campo, resúmenes de tesis, noticias, información sobre eventos, revisiones de libros, avisos de congresos, etc.

Los manuscritos pueden estar redactados en inglés, portugués o español. En el caso de autores cuya lengua materna no sea el inglés y envíen manuscritos en ese idioma, deberán someter el texto a una revisión detallada por una persona angloparlante nativa o traductor profesional.

Los manuscritos que no cumplan con las normas establecidas serán devueltos a los autores sin pasar al proceso de revisión por pares. Todos los manuscritos que son considerados apropiados por los editores son sometidos a revisión externa. El sistema de arbitraje recurre a al menos dos evaluadores por manuscrito que no pertenecen al comité editorial.

Las normas editoriales detalladas se pueden bajar de la página https://www.xenarthrans.org/es/revista-edentata/.

\section{INSTRUÇÕES AOS COLABORADORES}

Edentata é a publicação oficial, anual e com arbitragem científica do Grupo de Especialistas em Tamanduás, Preguiças e Tatus da IUCN/SSC (IUCN/SSC Anteater, Sloth and Armadillo Specialist Group). Tem como finalidade a difusão de informações que contribuam para a conservação dos xenartros.

Incentiva-se a submissão de manuscritos dentro de uma ampla variedade de tópicos, mas só são aceitos trabalhos que apresentem contribuições significativas à conservação dos xenartros. O tópicos incluem taxonomia, sistemática, genética, biogeografia, ecologia, conservação, comportamento e saúde. Os manuscritos devem ser trabalhos originais, que não foram publicados ou submetidos simultaneamente a outros periódicos. Qualquer sobreposição de conteúdo com artigos já publicados deve ser mínima. Edentata incentiva também a submissão de comunicações breves, notas de campo, resumos de teses, informações sobre eventos, revisões de livros, avisos de congressos, entre outros.

Os manuscritos podem ser redigidos em inglês, português ou espanhol. Aos autores cuja língua materna não seja o inglês, e que optem por enviar manuscritos nesse idioma, solicita-se uma revisão detalhada por pessoa nativa ou tradutor profissional. Assim que os manuscritos são recebidos, os editores fazem uma primeira avaliação.

Os manuscritos que não estejam de acordo com as normas editoriais são devolvidos aos autores, sem revisão. Os manuscritos considerados apropriados pelos editores são submetidos à revisão por pares. O processo de revisão de cada manuscrito envolve a avaliação de pelo menos dois revisores, que não podem ser membros do comitê editorial. 


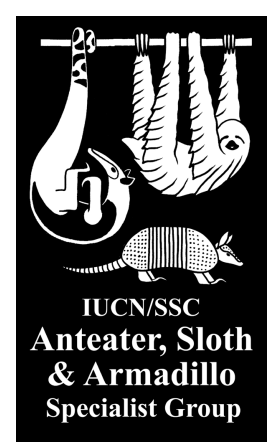


The Newsletter of the IUCN/SSC Anteater, Sloth and Armadillo Specialist Group

December $2019 \bullet$ Number 20

\section{Table of Contents}

Letter from the Editors..........................................................................................................................................i

IUCN/SSC Anteater, Sloth and Armadillo Specialist Group Members 2017-2020 ....................................... iii

\section{ARTICLES}

Guidelines to identify individual giant armadillos, Priodontes maximus (Kerr, 1792), through camera traps

Gabriel Fávero Massocato \& Arnaud L. J. Desbiez

\section{SHORT COMMUNICATIONS}

Noteworthy records of the northern naked-tailed armadillo, Cabassous centralis (Cingulata: Chlamyphoridae), in Guatemala, Central America.

José Manuel Pellecer, Julio Rafael Morales \& Sergio Guillermo Pérez

Nuevos registros en Huánuco (Perú) y distribución potencial del armadillo peludo (Dasypus pilosus) 22

E. Daniel Cossios \& Pedro Huanca-Foroca

Nuevos casos de comportamiento agonístico entre machos adultos de Bradypus variegatus en el Caribe colombiano

Jairo Andrés Díaz Arcia \& Julio J. Chacón Pacheco

Report of three non-agonistic encounters of free-living giant anteaters (Myrmecophaga tridactyla)... 31 Mariana Labão Catapani, Karina Theodoro Molina, Alexandre Martins Costa Lopes \& Flávia Miranda

Reporte de un ejemplar albino de Tamandua tetradactyla (Linnaeus, 1758) (Pilosa, Myrmecophagidae) en el suroeste de Paraguay

Sergio D. Ríos, Christian Ruiz Díaz \& Paul Smith

\section{FIELD NOTES}

Primeiro registro de leucismo em Bradypus variegatus (Schinz 1825, Xenarthra: Bradypodidae), município de Maceió, Alagoas, Brasil.

Ana Cecília Pires de Azevedo Lopes, Epitacio Correia de Farias Junior, Marco Antônio de Freitas \& Karina Theodoro Molina

News.

Notes to Contributors / Pautas para los Colaboradores / Instruções aos Colaboradores 